
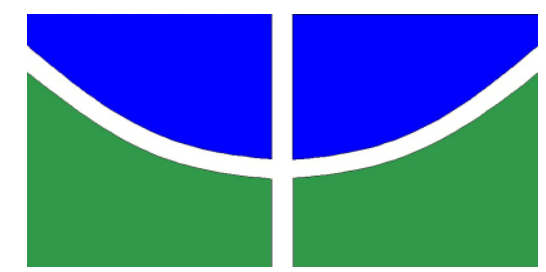

UNIVERSIDADE DE BRASÍLIA

Instituto de Ciências Biológicas

Instituto de Física

Instituto de Química

Faculdade UnB Planaltina

Programa de Pós-Graduação em Ensino de Ciências

Mestrado Profissional em Ensino de Ciências

\title{
A EDUCAÇÃO ALIMENTAR NO ENSINO DE CIÊNCIAS: O CASO DAS DIETAS ALIMENTARES
}

LAYS BATISTA MARTINS LEITE

Brasilia, DF

(2016) 


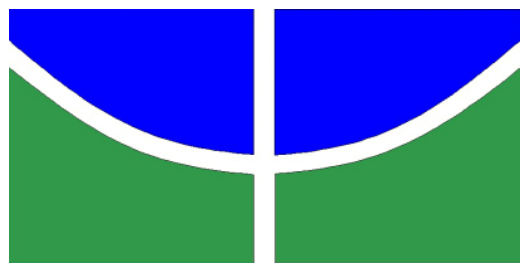

UNIVERSIDADE DE BRASÍLIA - UnB

Instituto de Ciências Biológicas

Instituto de Física

Instituto de Química

Faculdade UnB Planaltina

Programa de Pós-Graduação em Ensino de Ciências

Mestrado Profissional em Ensino de Ciências

\section{A EDUCAÇÃO ALIMENTAR NO ENSINO DE CIÊNCIAS: O CASO DAS DIETAS ALIMENTARES}

LAYS BATISTA MARTINS LEITE

Dissertação realizada sob orientação da Prof. ${ }^{a}$ Dr. ${ }^{a}$ Mariana de Senzi Zancul e do Prof. Dr. Gerson de Souza Mól e apresentado à banca examinadora como requisito parcial à obtenção do Título de Mestre em Ensino de Ciências - Área de concentração "Ensino de Ciências", pelo Programa de Pós-Graduação em Ensino de Ciências da Universidade de Brasília.

Brasilia, DF

(2016) 


\section{FICHA CATALOGRÁFICA}

Leite, Lays Batista Martins

A Educação Alimentar no Ensino de Ciências: O Caso das Dietas Alimentares. Lays Batista Martins Leite. Brasília, Programa de Pós Graduação em Ensino de Ciências (PPGEC) - Universidade de Brasîlia, 2016.

$129 \mathrm{p}$.

Dissertação de Mestrado - Universidade de Brasília, Instituto de Biologia, Instituto de Física, Instituto de Química, Faculdade UnB Planaltina.

Área de Concentração: Ensino de Ciências.

1. Educação Alimentar. 2. Ensino de Ciências. 3. Dietas Alimentares. 4. Papel do professor e da Escola. II Título. 
FOLHA DE APROVAÇÃO

LAYS BATISTA MARTINS LEITE

“A Educação Alimentar no Ensino de Ciências: O Caso das Dietas Alimentares”

Dissertação apresentada à banca examinadora como requisito parcial à obtenção do Título de Mestre em Ensino de Ciências, pelo Programa de Pós-Graduação em Ensino de Ciências (PPGEC) da Universidade de Brasîlia (UnB).

Aprovada em 01 de março de 2016.

BANCA EXAMINADORA

Prof. ${ }^{a}$ Dr. ${ }^{a}$ Mariana de Senzi Zancul - IB/UnB

(Presidente)

Prof. ${ }^{a}$ Dr. ${ }^{a}$ Lívia Penna Firme Rodrigues - FUP/UnB

(Membro Titular)

Prof. ${ }^{a}$ Dr. ${ }^{a}$ Maria Rita Avanzi - IB/UnB

(Membro Titular)

Prof $^{\mathrm{a}} \mathrm{Dr}^{\mathrm{a}}$ Alice Melo Ribeiro - IB/UnB

(Membro Suplente) 
Dedico este trabalho a todos os professores que confiam que a educação é o caminho para a transformação de trajetórias de vida, e que mesmo diante de todas as dificuldades acreditam no seu papel social e no potencial de seus alunos. 


\section{AGRADECIMENTOS}

Agradeço imensamente a Deus, por guiar constantemente minhas decisões e tornar tudo que almejo concreto, inclusive o ingresso e a conclusão no curso de mestrado.

Aos meus pais, Francisca e Milton, que acompanham com carinho minha carreira acadêmica, obrigada por me incentivar ao longo dessa jornada e por disponibilizar todos os recursos para que eu me tornasse a pessoa que sou hoje, sem vocês evidentemente eu não teria chegado até aqui.

Ao futuro médico, meu irmão Milton Batista Leite Júnior, por ser um amigo de todas as horas. Você é meu modelo de dedicação e determinação.

Aos meus avós, Tereza, José, Andrelina e Benjamin (in memorian), que são meus exemplos de dignidade, honestidade e respeito mútuo, eu amo vocês.

Aos meus familiares, em especial, a minha madrinha Cristiane e as minhas primas amadas Layla, Evelyn e Nicolly, por todo o amparo, zelo e por sempre desejarem o melhor para mim.

Às prof. ${ }^{\text {as }}$ Dr. ${ }^{\text {as }}$ Cynthia Bisinoto, Maria de Lourdes Lazzari de Freitas, Renata Cardoso de Sá Ribeiro Razuck e ao professor MsC. Franco de Salles Porto que foram cruciais no meu ingresso e conclusão no curso de mestrado. Fico lisonjeada de tê-los como mestres, vocês são exemplos de excelência no trabalho docente.

Aos meus queridos orientadores, prof. Dr. Gerson de Souza Mól e prof. ${ }^{a}$ Dr. $^{\mathrm{a}}$ Mariana de Senzi Zancul, por compartilharem comigo seus conhecimentos, pelas contribuições na minha formação acadêmica e por me conduzirem com profissionalismo e dedicação.

A todos os meus amigos por compreenderem meus dilemas e ausências.

Às minhas amigas Gabriela Dutra, Samara dos Anjos, Antonia Adriana, Luana Oliveira e Ivaneide Alves por tornarem os meus dias mais leves, com a companhia de vocês tudo se torna mais feliz.

Aos professores do curso de graduação em Ciências Naturais do campus UnB Planaltina, por serem profissionais exímios e por contribuírem imensamente para a minha formação.

A banca examinadora deste estudo, constituída pelas prof. ${ }^{\text {as }}$ Dr. ${ }^{\text {as }}$ Alice Melo Ribeiro, Lívia Penna Firme Rodrigues e Maria Rita Avanzi. Muito obrigada por todas as 
considerações e disponibilidade de agregar conhecimentos importantes a esta dissertação.

Aos professores do Programa de Pós-Graduação em Ensino de Ciências da UnB por compartilharem diariamente experiências e conhecimentos valiosos.

Aos meus amigos de curso e de vida, MsC.Samara dos Anjos da Costa, MsC. Antonia Adriana Mota Arrais e MsC. Rodrigo Xavier por todo o apoio e compreensão nos momentos difíceis, e pelas conversas alegres ao longo destes dois anos de mestrado.

Aos professores e a direção do Centro de Ensino Fundamental 01 de PlanaltinaDF, em evidência minhas amigas Natane, Jany, Katharine, Rosiene, Angélica, Elisângela e Janaína, vocês tornaram minha primeira experiência docente única, obrigada pelo companheirismo.

Aos meus queridos alunos pelo carinho e ensinamentos diários, o crescimento de vocês me torna uma profissional e pessoa melhor.

Agradeço a todos que de alguma forma auxiliaram neste estudo e almejaram o meu êxito nessa fase. 
'Não há educação sem amor. O amor implica na luta contra o egoísmo. Quem não é capaz de amar os seres inacabados não pode educar. Não há educação imposta, como não há amor imposto. Quem não ama não compreende o próximo, não o respeita.

Não há educação do medo. Nada se pode temer da educação quando se ama." 


\section{RESUMO}

A educação alimentar é considerada indispensável no ambiente escolar, uma vez que a alimentação adequada e sustentávelé essencial para saúde humana. Apesar de o tema no âmbito escolar fazer parte dos temas transversais nos Parâmetros Curriculares Nacionais (PCN), ainda concentra-se excessivamente na vertente biológica do assunto, promovendo apenas a transmissão do conteúdo específico, na maioria das vezes, com enfoque puramente biologicista. Ou seja, a abordagem da temática não possibilita a formação do pensamento crítico dos estudantes e se limita as aulas de ciências e biologia. Deste modo, este estudo fomenta a realização de uma Unidade Didática a respeito de educação alimentar na escola, desenvolvendo subsídios que auxiliem a intervenção pedagógica de forma interdisciplinar englobando principalmente aspectos químicos e biológicos e considerando os aspectos sociais, culturais, emociona is que se relacionam à temática. A proposta metodológica deste estudo caracteriza-se como uma pesquisa-intervenção, envolvendo a aplicação de um questionário inicial para 20 adolescentes que estavam cursando séries distintas do Ensino Médio. A partir das considerações coletadas e analisadas desenvolveu-se um material didático que é constituído por dez atividades de ensino que visam problematizar a educação alimentar. Em um segundo momento, a Unidade Didática elaborada foi implantada com outros 21 alunos que cursavam o $8^{\circ}$ ano do Ensino Fundamental, objetivando avaliar o impacto e interação das estratégias de ensino com o referido público. Ao final da aplicação da proposição os mesmos discentes responderam a um questionário final. $\mathrm{O}$ uso das atividades propostas no material didático proporcionou a interação do conhecimento alusivo à alimentação entre os discentes, permitido a reflexão de padrões conferidos diariamente pelo meio em que estão inseridos. Tendo em vista, os dados obtidos, conclui-se que a educação alimentar deve estar continuamente presente no ambiente escolar. Além disso, o trabalho pedagógico nesta área não está unicamente associado à disciplina de ciências, mas igualmente nos demais campos do conhecimento.

Palavras chave: Educação Alimentar. Ensino de Ciências. Dietas Alimentares. Papel do professor e da escola. 


\begin{abstract}
Nutrition education is considered indispensable in the school environment, as adequate and sustainable food is essential for human health. Although the subject in schools part of the trans versal themes in the National Curricular Parameters (PCN), still focuses too much on biological aspects of the subject, promoting only the transmission of specific content, in most cases, purely biological focus. Ie the thematic approach does not allow the formation of critical thinking of students and limited classes of science and biology. Thus, this study promotes the realization of a teaching unit about food education at school, developing grants to assist the pedagogical intervention interdisciplinary approach encompassing mainly chemical and biological aspects and considering the social, cultural, emotional aspects that relate to the theme. The methodology of this study is characterized as a research-intervention, involving the application of an initial questionnaire to 20 teenagers who were attending different grades of high school. From considerations collected and analyzed developed a courseware that consists of ten educational activities that aim to discuss food education. In a second step, the Teaching Unit prepared was implanted with 21 other students who were in the 8th grade of elementary school, to evaluate the impact and interaction of teaching strategies with that audience. At the end of the application of the proposition the same students completed a final questionnaire. The use of the proposed activities in the teaching material provided the interaction of knowledge alluding to food among students, allowed the reflection patterns checked daily by the environment in which they live. Considering the data obtained, it is concluded that food education must be continuously present in the school environment. In addition, the pedagogical work in this area is not only associated with the discipline of science, but also in other fields of knowledge.
\end{abstract}

Keywords: Nutrition Education. Science Education. Food Diets. Role of the teacher and school. 


\section{LISTA DE ILUSTRAÇÕES}

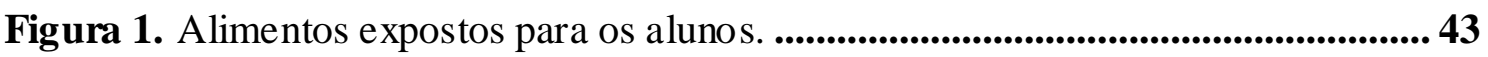

Figura 2. Participantes elaborando cartazes acerca da pesquisa realizada. ...................... 45

Figura 3. Cartaz produzido pelos participantes (Grupo 3). ........................................... 46

Figura 4. Cartaz produzido pelos participantes (Grupo 4). .............................................. 47

Figura 5. Alimentos escolhidos pelos discentes: Sorvete, guacamole, cuscuz, feijão

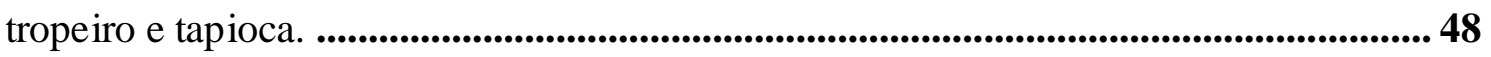

Figura 6. Cartaz sobre dietas alimentares restritivas (Grupo 3) ......................................50

Figura 7. Quantidade de açúcar presente em bebidas industrializadas. .........................5 52

Figura 8. Estande de apresentação no V Circuito de Ciências, etapa regional................58

Figura 9. Materiais produzidos pelos alunos para a apresentação................................58

Figura 10. Apresentação na Semana Nacional de Ciência e Tecnologia. .......................59 


\section{LISTA DE TABELAS}

Tabela 1. Faixa de idade dos participantes do questionário inicial. 38

Tabela 2. Dietas alimentares que os participantes possuem conhecimento......................40

Tabela 3. Fonte de informações que os alunos utilizam para pesquisar sobre alimentação. .................................................................................................................................................. 40

Tabela 4. $\mathrm{O}$ estudo das dietas alimentares na escola. ..................................................... 41 


\section{SUMÁRIO}

APR ESENTAÇÃ̃ ….................................................................................................... 15

1 INTRODUÇÃO ......................................................................................... 16

2 REFERENCIAL TEÓRICO .................................................................. 19

2.1 Alguns Aspectos da EduCAÇÃo ALIMENTAR No BRASIL................................. 19

2.2 Dietas Alimentares: Considerações Gerais e a InfluÊnCIA DA Mídia .... 22

2.3 A FormaÇÃo de HÁBITOS AlimentARES SAUdÁ veIS ........................................... 25

2.4 O PAPEL Do PROFESSOR EDA ESCOLA NA EdUCAÇÃo ALIMENTAR ....................... 28

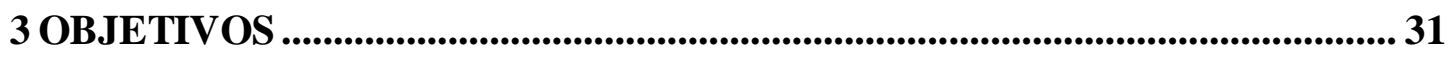

3.1 OBJETIVO GERAL........................................................................................................... 31

3.2 OBJETIVOS ESPECÍFICOS ........................................................................................ 31

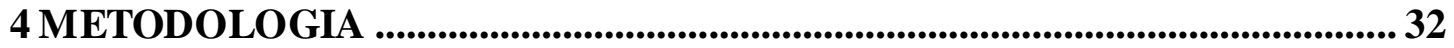

4.1 INSTRUMENTOS DE INVESTIGAÇÃO ........................................................................... 33

4.1.1 QUESTIONÁRIO INICIAL EPARTICIPANTES ............................................................. 33

4.1.2 QUESTIONÁRIO FINAL E PARTICIPANTES.................................................................. 34

4.1.3 OBSER VAÇÕES ........................................................................................................35

4.2 PROCESSO DE CONSTRUÇÃO DAS INFORMAÇÕES ....................................................... 35

4.4 PROPOSIÇÃO EDUCATIVA...............................................................................................36

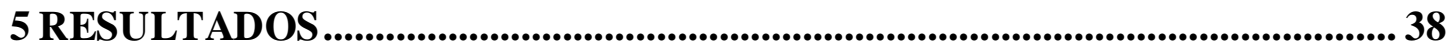

5.1 QUESTIONÁRIO INICIAL................................................................................................38

5.2 RELATO DA PROPOSIÇÃo EdUCATIVA ........................................................................ 42

5.2.1 ATIVIDADE 1 - CONHECENDO OS ALIMENTOS ...................................................... 43

5.2.2 ATIVIDADE2 -OS AlIMENTOS NO COTIDIANO..................................................... 44

5.2.3 ATIVIDAde 3 - A RelaÇão da AlimentaÇão com os Fatores Sociais ..... 45

5.2.4 ATIVIDADE 4 - A AlimentaÇÃO NAS DiverSas CulTuRAS................................. 47

5.2.5 Atividade 5 - Dietas Alimentares: Situações PROBlemaS........................ 49

5.2.6 ATIVIDADE 6 - A INFLUÊNCIA DA Mídia NAS DieTAS AlimeNTARES ...............50

5.2.7 ATIVIDADE 7 - FAST FOODS E OS IMPACTOS NA SAÚDE HUMANA ......................51

5.2.8 ATIVIDADE 8 - DIÁRIO ALIMENTAR ..................................................................... 53

5.2.9 ATIVIDADE 9 - TRANSTORNOS ALIMENTARES.....................................................5 54

5.2.10 ATIVIDADE 10 - CoMPARTILHANDO OS SABERES ADQUIRIDOS ........................ 55 
5.3 QUESTIONÁRIO FINAL..............................................................................................5 55

5.4 V CiRCUITO de CiÊNCIAS E SEMANA NACIONAL DE CiÊNCIA E TECNOLOGIA .... 57

6 DISCUSSÃO ....................................................................................................... 61

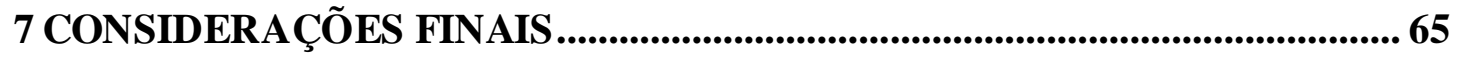

REFERÊNCIAS BIBLIOGÁFICAS ..........................................................6 67

APÊNDICE A - QUESTIONÁRIO INICIAL PARA OS ALUNOS ................................... 74

APÊNDICE B - QUESTIONÁRIO FINAL PARA OS ALUNOS.......................................... 76

APÊNDICE C - CARTA DE ACEITE INSTITUCIONAL ................................................... 77

APÊNDICE D - TERMO DE CONS ENTIMENTO LIVRE E ESCLARECIDO ..................... 78

APÊNDICE E - SITUAÇÕES PROBLEMAS SOBRE DIETAS ALIMENTARES (ATIVIDADE 5) 79

APÊNDICE F - ATIVIDADE COMPLEMENTAR (ATIVIDADE 8) ..................................8 80

APENNDICE G - ATIVIDADE COMPLEMENTAR (ATIVIDADE 9) ............................ 81

APÊNDICE H - ATIVIDADE COMPLEMENTAR (ATIVIDADE 10) .................................82

ANEXO A - TEXTO DE DiVULGAÇÃO CIENTÍFICA (ATIVIDADE 3) ............................83

ANEXO B - TEXTO DE DIV ULGAÇÃO CIENTÍFICA (ATIVIDADE 9) .............................. 85 


\section{APRESENTAÇÃO}

O meu interesse pela licenciatura iniciou-se desde o princípio da minha vida escolar, enquanto cursava o Ensino Médio desenvolvi proximidade com as disciplinas de biologia e química, logo optei por pleitear a vaga no curso de licenciatura em Ciências Naturais na Universidade de Brasília, já que este tem cunho interdisciplinar com esses campos de estudo.

Após o ingresso na Universidade tive a oportunidade de participar de alguns projetos, sendo eles: Projeto Interdisciplinar em Ensino de Ciências - A FUP vai para as escolas em Planaltina -DF; Integração Psicologia e Educação: Articulações para a Formação Profissional; e Programa Institucional de Bolsa de Iniciação a Docência (PIBID). Todos os projetos mencionados possuíam o intuito de aperfeiçoar e valorizar a formação do estudante de licenciatura para sua posterior a tuação como docente. Durante este período obtive experiências relevantes para minha formação acadêmica e profissional, acrescendo meu anseio por me tornar uma professora e pesquisadora na área de Ensino de Ciências.

Ao finalizar o curso de graduação visei dar continuidade a minha formação acadêmica, ingressando no curso de Mestrado Profissional em Ensino de Ciências na Universidade de Brasília, sob a orientação dos professores Mariana de Senzi Zancul e Gerson de Souza Mól. Ao cursar a disciplina de educação em saúde, ministrada pela minha orientadora, identificamos a possibilidade de formular uma Unidade Didática que abordasse o tema dietas alimentares, uma vez que a partir da leitura e discussão de textos notou-se que o assunto ainda é pouco consolidado no contexto de sala de aula.

Até então a educação alimentar era um assunto distante para mim e ao perceber as outras vertentes inerentes ao tema - históricas, psicológicas, culturais e sociais comecei a me aprofundar e a compreender a importância de inserir a temática na escola, dispensando o foco excêntrico na questão nutricional, buscando valorizar as experiências do educando em relação às concepções intrínsecas a sua alimentação. 


\section{INTRODUÇÃO}

A alimentação é um fator fundamental para a manutenção do organismo humano, configura-se, além disso, em uma fonte de prazer e um determinante primordial para saúde dos indivíduos. Loureiro (2004, p. 43), enfatiza que a alimentação "traduz as condições de vida de cada um, o contexto em que se move a cultura que perfilha. Sendo um traço de identidade, é também o reflexo das pressões sociais". As escolhas alimentares dos seres humanos baseiam-se especialmente no fato da sua condição onívora, isto é, apresenta à liberdade de comer de tudo, entretanto, diversos fatores influenciam essa decisão, desde o ambiente até a história individual, assim como suas relações sociais com os demais sujeitos (JOMORI; PROENÇA; CALVO, 2008). Boog (2008, p. 19-20) enfatiza que:

A alimentação é uma atividade central da vida, que define a nossa
forma de viver, de morar e de organizar a sociedade. As cidades são
formadas às margens dos rios, porque eles proporcionam condições de
suprir a necessidade de água e de alimentos. O dia divide-se em turnos
porque, no meio deles, precisamos parar as atividades para comer. A
palavra salário deriva de "sal", porque em tempos antigos o trabalho
era trocado por essa substância de valor que conferia sabor aos
alimentos. Enfim... as atividades de alimentação proporcionam a
apreensão da cultura alimentar; a assimilação de valores sociais e
éticos, o exercício das práticas de comensalidade, que se referem à
forma humana de fazer da alimentação um ato social revestido de
prazer e convivialidade.

Os comportamentos alimentares são influenciados culturalmente e são estabelecidos pela sociedade padrões que contribuem para uma idealização corporal, assim, existem grupos específicos na sociedade moderna que buscam constantemente pela suposta "perfeição", ou seja, coloca-se em primeiro lugar a imagem ao invés da saúde, tornando o uso de dietas restritivas imensamente presentes no cotidiano do indivíduo, além daqueles que não se preocupam em ter uma alimentação adequada, muitas vezes por comodidade, modismo e praticidade. Para Schmitz et al (2008, p. 312):

As transformações ocorridas no Brasil, relacionadas à crescente modernização e urbanização, estão associadas a mudanças no estilo de vida e nos hábitos alimentares da população, sendo estas mudanças 
consideradas como favorecedoras para o desenvolvimento das doenças crônicas não transmissíveis.

Acerca do uso de dietas restritivas, Deram (2014) afirma que estas se tornaram um estilo de vida na sociedade em que vivemos. No entanto, a questão não é só deixar de ingerir um determinado alimento e fazer atividades físicas. O principal é estabelecer uma relação saudável com os alimentos, tornando prazeroso o ato de comer.

Contreras e Gracia (2011, p. 304) corroboram que “[...] a comida não é apenas uma necessidade biológica, mas suas funções sociais e psicológicas são muito significativas". Comer envolve múltiplos fatores, como a comunicação, interação, fortalecimento de laços familiares e bem-estar, que cooperam para formação do pensamento do sujeito. Nesse sentido, ressalta-se o papel da escola, que possui a possibilidade de intervir positivamente no desenvolvimento das pessoas e da sociedade (BISINOTO, 2012).

A educação alimentar é considerada indispensável no ambiente escolar, uma vez que a alimentação adequada e sustentável é essencial para saúde humana. Sendo assim, a aprendizagem acerca dessa temática irá influenciar os hábitos alimentares dos indivíduos ao longo de sua vida (ZANCUL; DUTRA-DE-OLIVEIRA, 2007). Contudo, no decorrer das vivências escolares, nota-se que tal assunto é abordado pelos educadores evidenciando o aspecto puramente biológico.

A Lei no 9.394/96, que estabelece as Diretrizes e Bases da Educação Nacional (BRASIL, 2014a), faz menção em seu texto a respeito da alimentação e saúde em dois momentos: no Artigo $4^{\circ}$, inciso VIII e no Artigo $71^{\circ}$, inciso IV. O enfoque principal é dado aos programas de suplementação alimentar e de assistência à saúde (BRASIL, 2014a). Já os Parâmetros Curriculares Nacionais (BRASIL, 1998) sugerem que o tema seja abordado como tema transversal, ou seja, valorizando a interdisciplinaridade e contribuindo para favorecer a construção de valores relacionados à saúde.

Para que o tema educação alimentar seja tratado como objeto de estudo no ambiente escolar, é preciso explorar os conhecimentos de caráter social, afetivo, psicológico e cultural, uma vez que os alunos trazem consigo diversas concepções acerca do assunto (FONSECA; LOGUERCIO, 2013). Costa (2009, p. 135-136) enfatiza que:

Nos últimos anos, a alimentação tem recebido uma atenção crescente. De fato, na alimentação, o biológico e o cultural se encontram. Porém, mais do que responder a uma necessidade básica do organismo, $\mathrm{o}$ ato 
de comer é uma prática cultural que implica relações sociais, crenças, classificações, enfim, formas de conceber o mundo. A alimentação tem, então, um grande poder simbólico, marcando identidades individuais e sociais e, mais profundamente, algo que implica na relação natureza e cultura. Trata-se, assim, de um campo privilegiado para discussão.

Libâneo (1996) afirma que a aprendizagem tem um vínculo com as percepções sociais do indivíduo, a apropriação dos conhecimentos relaciona-se com todos os campos de vivência do aluno. Partindo deste pressuposto, insere-se neste contexto a figura do professor, que terá como compromisso a humanização dos saberes no processo de ensino aprendizagem. No que ser refere ao tema em pauta, o papel do professor seria o de apresentar o conhecimento como uma construção histórica e social, valorizando a significação dos alimentos para os discentes, visando à sua autonomia.

Manço e Costa (2004) salientam que no Brasil a educação neste campo sempre se associou aos interesses econômicos, de maneira que o alimento é constituído de valores distintos pelas classes sociais. As ações pedagó gicas em educação alimentar se tornaram um tipo de "educação bancária", cujo objetivo tornou-se apenas a transmissão do saber, na qual os alunos são receptores e o professor detentor do conhecimento (FREIRE, 2005). De acordo com a premissa que o homem não pode ser objeto de sua educação e sim sujeito desta, destaca-se a proposta de educação problematizadora a partir de temas geradores, com a perspectiva de aproximar os conhecimentos das necessidades dos estudantes (FREIRE, 2005; FREIRE, 2011; LIMA; COSTA, 2005). Loureiro (2004, p. 45), afirma que "educar para comer bem, de uma forma saudável, constitui um desafio às capacidades crítica e de assertividade para contrapor ao meio circundante a sua vontade esclarecida".

Considerando os estudos referidos anteriormente, propõe-se investigar a percepção de adolescentes acerca das dietas alimentares e indicar posteriormente possibilidades de abordagem da Educação Alimentar na escola, objetivando uma postura reflexiva e crítica dos estudantes em relação à temática.

Deste modo, este estudo fomenta a realização de uma Unidade Didática a respeito de educação alimentar na escola, desenvolvendo subsídios que auxiliem a intervenção pedagógica de forma interdisciplinar englobando principalmente aspectos químicos e biológicos e considerando os aspectos sociais, culturais, emocionais que se relacionam à temática. 


\section{REFERENCIAL TEÓRICO}

\subsection{Alguns Aspectos da Educação Alimentar no Brasil}

O Termo educação em saúde é condizente a situações compatibilizadas com a experiência de ensino e aprendizagem, com o desígnio de facilitar a autonomia do indivíduo atrelada à saúde. Define-se ainda, que promoção à saúde envolve a utilização de recursos educacionais que objetivam intervir positivamente nas condições de saúde (CANDEIAS, 1997). À vista destas considerações, a educação alimentar engloba ações que estão vinculadas a esses termos que tencionam gerar uma boa qualidade de vida dos sujeitos de acordo com a formação dos hábitos alimentares.

A educação alimentar no Brasil tornou-se vigente a partir da década de 1940 envolvendo principalmente a necessidade de fundamentar a introdução de novos alimentos na sociedade brasileira, dirigindo-se prioritariamente à mudança de hábitos alimentares. Durante esse período o objetivo da educação alimentar era unicamente a correção de hábitos alimentares da população de baixa renda, já que nesta época havia um grande índice de desnutrição (SANTOS, 2005).

Entre os anos 1950 e 1960 a educação nesta área abrangeu especialmente a questão econômica, estando relacionada à inserção de soja na alimentação devido, sobretudo, a expansão da lavoura comercial deste alimento. Nesse período, o governo brasileiro procurou promover estratégias educativas, que fomentassem uma alimentação baseada no programa de ajuda alimentar internacional, implantado pela United States Agency for International Development (USAID) (BOOG, 1997). Ainda na década de 1960, a educação em saúde era pautada na responsabilização do sujeito pelos problemas relativos à sua saúde (LIMA; COSTA, 2005).

A partir de 1970 devido às críticas feitas à educação alimentar vigente na época, visou-se estabelecer outra perspectiva para a suplementação alimentar. Neste contexto emergiu a concepção de que o único obstáculo para uma alimentação saudável era a renda financeira. Portanto, o poder econômico seria o único fator gerador de uma má alimentação e problemas de saúde (BOOG, 1997; SANTOS, 2005). 
Até então não havia publicações de artigos ou livros sobre educação alimentar, existiam apenas publicações referentes a folders ou livretos que tinham pouco a contribuir para esta área (MANÇO; COSTA, 2004).

Em meados dos anos de 1990 dominava a concepção que o comportamento adquirido pelo sujeito era responsável por ocasionar problemas de saúde, logo o incentivo para gerar mudanças nos hábitos alimentares e fortalecer atitudes consideradas saudáveis se constituiria na solução para o problema de saúde da população, essas condições envolviam o balanceamento de nutrientes ingeridos diariamente (LIMA; COSTA, 2005). Até essa década havia pouca valorização na educação alimentar, ganhando maior enfoque devido ao surgimento de doenças crônicas degenerativas, como: hipertensão, diabetes, câncer e obesidade, provocadas pela alimentação inadequada (RODRIGUES; RONCADA, 2008).

Somente em 1996 a educação alimentar surgiu como uma demanda de mobilização social, enfatizando questões sobre cultura, ética e cidadania, configurando a alimentação como um direito humano (SANTOS, 2005). No começo do século XXI a educação para saúde "torna-se um instrumento de construção de participação popular" (LIMA; COSTA, 2005, p. 33), preocupando-se com os profissionais que atuam no contexto e na adoção de medidas que visassem diminuir as desigualdades sociais e econômicas presentes entre as instituições e os sujeitos, desfazendo o vínculo prioritário com os interesses econômicos das classes dominantes (LIMA; COSTA, 2005).

Desde o ano 2000, em decorrência da alimentação e estilo de vida, houve um aumento relevante de casos de sobrepeso e obesidade, elevando os índices de mortalidade e morbidade provocados pelas doenças crônicas degenerativas (RODRIGUES; RONCADA, 2008). Em 2011 o Ministério da Saúde divulgou uma pesquisa quantitativa realizada com 54.144 brasileiros, destacando que a alimentação de pessoas adultas era inadequada. Tanto, homens como, mulheres demonstraram diferentes níveis de prevalência de doenças crônicas degenerativas. De acordo com a apresentação de tais dados, corrobora-se que a grande quantidade da população adulta com sobrepeso e obesidade será o maior desafio para as políticas públicas de saúde para os próximos anos, uma vez que se constatou que 48,5\% da população brasileira esta acima do peso (MALTA et al, 2013).

As estratégias de reversão da alta proporção de obesidade e sobrepeso envolvem o investimento em uma alimentação saudável e o incentivo a práticas de exercícios 
físicos. Em consequência desta pesquisa, o Ministério da Saúde criou programas de prevenção e tratamento, sendo eles: programa academia da saúde e linha de cuidado a atenção básica ao excesso de peso e outros fatores de risco que estão relacionados ao sobrepeso e obesidade (MALTA et al, 2013).

Em razão dos avanços tecnológicos e das mudanças ocorridas nos padrões alimentares ao longo dos anos, a relação dos indivíduos com os alimentos também passou por diversas transformações, culminando na restrição de determinados alimentos, como por exemplo, o açúcar, gorduras no geral, carboidratos, manteiga, doce etc. Gerando assim, uma dicotomia do alimento entre apropriado ou inapropriado (DERAM, 2014). Tendo em vista as considerações enfatizadas, a ed ucação alimentar na escola tende a nortear as ações dos educandos para que eles possam vislumbrar o ato de se alimentar como essencial para vida, e que cada organismo reage de maneira diferente diante da dieta alimentar aderida.

De acordo com Santos (2005, p. 689):

As propostas de inclusão dos temas de segurança alimentar nos projetos pedagógicos escolares, nos diferentes níveis de ensino, podem contribuir para a instrumentalização dos indivíduos, permitindo aos sujeitos "navegarem" nesse mar de informações. No entanto, é necessário aprofundar o "como" tais "inclusões" se concretizariam. Seria importante considerá-las dentro das discussões político-filosófico do ensino brasileiro, não reduzindo o tema à mera inclusão de conteúdos.

Apesar de o tema educação alimentar no âmbito escolar fazer parte dos temas transversais nos Parâmetros Curriculares Nacionais (PCN), ainda concentra-se excessivamente na vertente biológica do assunto, promovendo apenas a transmissão do conteúdo específico, na maioria das vezes, com enfoque puramente biologicista. Ou seja, a abordagem da temática não possibilita a formação do pensamento crítico dos estudantes e se limita as aulas de ciências e biologia, reforçando a concepção de que a alimentação abarca unicamente a questão da sobrevivência humana, não levando em conta a importância cultural e social do ato de comer (ZANCUL; GOMES, 2011). 


\subsection{Dietas Alimentares: Considerações Gerais e a Influência da Mídia}

A palavra dieta origina-se do grego e deriva da palavra díaita, seu significado está associado ao modo de viver de cada indivíduo, ou seja, com hábitos alimentares diários. No dicionário a definição da palavra dieta refere-se a regime alimentar, englobando a abstenção de alguns ou todos os alimentos, geralmente em caso de doença ou com finalidade de perda de peso (FERREIRA, 2001).

O conceito de dieta com intuito de perda de peso e condições saudáveis, segundo Santos (2010), remete a uma concepção recente que surgiu a partir do século XX. A autora destaca que mesmo na era contemporânea as dietas ainda são vislumbradas como padrões desenvolvidos por classes econômicas com maior poder aquisitivo, com o objetivo de realizar sacrifícios, tornando o ato de comer extrínseco ao cotidiano dos sujeitos.

De acordo com Carneiro (2003), um dos fatores que mais influenciaram as transformações dietéticas tem sido a guerra, não apenas por ocasionar a fome, mas também por promover hábitos alimentares a partir da inserção de novos tipos de alimentos, tais como a ração disponibilizada aos soldados. Além disso, a indústria, em alguns casos, ligada à guerra, configurou-se em um importante aspecto para a transformação da alimentação contemporânea. Deram (2014, p. 49) frisa que:

A maior revolução na história moderna da alimentação provavelmente ocorreu na época da industrialização e urbanização das grandes cidades, quando as populações deixaram de ter acesso à horta e à comida caseira, passando a depender da indústria e do mercado.

Para Garcia (2001), práticas alimentares estão arraigadas culturalmente e quando se realiza uma dieta restritiva há uma fragmentação dos elementos culturais, sociais e emocionais, desconsiderando fatores que compõem a formação dos hábitos alimentares de cada pessoa.

Radaelli e Recine (2004) corroboram que as dietas estão integradas aos costumes alimentares, e que é responsabilidade das autoridades gerarem políticas públicas que promovam à saúde. Neste sentido, as autoras ainda questionam que é necessário que a dieta humana seja equilibrada, pois as características presentes nas dietas individuais podem ser decisivas para um bom estado de saúde. 
Para além dos estudos e pesquisas científicas os livros didáticos também abordam o assunto, como por exemplo, o livro 'Química e Sociedade', destinado ao Ensino Médio, o termo dieta aparece em um texto complementar, ressaltando a ideia de que as dietas são hábitos alimentares cotidianos aderidos pelos indivíduos, e estes podem ou não ser saudáveis. Os autores ressaltam que novas compreensões acerca deste tema surgem constantemente, sugerindo que o aluno se mantenha informado a respeito dos alimentos que pretende consumir (SANTOS; MÓL, 2011).

Em relação a outros livros como os da disciplina de Biologia (LOPES; ROSSO, 2010), ou de Ciências Naturais (BARROS; PAULINO, 2011) para o Ensino Médio e Ensino Fundamental, na maioria dos casos encontra-se prioritariamente uma discussão acerca da quantidade de ingestão de determinada fonte de alimento para obter uma alimentação saudável. Isto é, foca-se mais nos aspectos bioquímicos, reduzindo a alimentação ao consumo de micro e macronutrientes.

Já em buscas rápidas feitas na internet, meio de comunicação bastante utilizado por adolescentes, é encontrada uma vasta quantidade de dietas restritivas com o intuito de emagrecimento, com ausência de precedentes científicos de sua eficácia. Além desse meio, revistas e emissoras de televisão fornecem informações que na maioria das situações desconsideram a realidade que o sujeito vivência. De acordo com Deram (2014), com o crescente avanço da tecnologia são expostas uma grande quantidade de dicas totalmente erradas e prejudiciais relativas a dietas restritivas. Segundo essa autora, não existe nenhum espaço social mediático que não tenha dicas sobre dietas que visem modelar o corpo ou auxiliar na beleza. As redes sociais se tornaram uma das principais fontes de democratização destas informações, as dicas de nutrição advêm de blogs, usuários do Facebook e do Instagram, expondo conhecimentos avulsos que se concentram predominantemente nas medidas corporais.

As dietas alimentares representam uma temática imensamente presente na mídia. Comerciais vinculados à alimentação são predominantes em várias fontes, sendo os principais veículos de comunicação. Esses meios evidentemente possuem a capacidade de despertar o anseio pelo consumo nos sujeitos. A forma como os recursos são expostos favorecem atração por um determinado elemento, estabelecendo, assim, padrões a serem seguidos.

Costa (2009) salienta que as agências de publicidade se reinventam a todo instante para atingir e convencer um determinado público alvo. Para essa autora, "o 
valor persuasivo da publicidade não se limita à compulsão de compra dos objetos, mas visa também à adesão ao consenso social do sentido que certo discurso sugere na relação do sujeito com os objetos e, consequentemente, com a sociedade" (p. 131).

As crianças e adolescentes estão suscetíveis à influência que a mídia dispõe, é comum encontrar jovens que buscam seguir um padrão estabelecido pelo marketing. A esse respeito, Moura (2010) salienta que, em concordância com o crescimento da exposição de produtos alimentícios divulgados pela mídia, há um aumento promocional de produtos prontos, como enlatados, congelados e fast foods, considerados práticos para o consumo.

O ideal de perfeição corporal, divulgado pelas mídias em geral, leva os adolescentes, a uma insatisfação constante com o seu corpo. Ocasionando a busca e adoção de dietas extremamente restritivas e exercícios físicos exorbitantes, destinandose alcançar o modelo corporal vigente na sociedade (ANDRADE; BOSI, 2003).

Serra e Santos (2003, p. 692) enfatizam que:

Os meios de comunicação veiculam ou produzem notícias, representações e expectativas nos indivíduos com propagandas, informações e noticiário em que de um lado estimulam o uso de produtos dietéticos e práticas alimentares para emagrecimento e, de outro, instigam ao consumo de lanches tipo fast food. Não se trata de uma decisão ou ação das empresas midiáticas, elas integram um contexto empresarial e um sistema de crenças em que há uma estreita relação entre uma suposta verdade biomédica e um desejo social e individual.

Além disso, é comum encontrar em algumas revistas sem embasamento científico centenas de "dietas da moda", que propõem o emagrecimento imediato. Essas dietas se tornam constantemente usuais e populares na sociedade. Entretanto, não são de grande valia, pois não levam em consideração outros aspectos da vida dos indivíduos, como as questões culturais, sociais e hábitos alimentares cotidianos (PACHECO; OLIVEIRA; STRACIERI, 2009). Costa (2009, p. 137) afirma que "os alimentos não podem ser considerados como simples fontes de nutrientes, pois além dessa característica não menos importante, carregam significações culturais, afetivas e comportamentais que não devem ser desprezadas".

Para Contreras e Gracia (2011), nas últimas três décadas, os transtornos gerados por dietas inadequadas com restrição de diversos nutrientes aumentaram substancialmente e, em todos os casos, os diagnósticos estão associados, principalmente, à anorexia ou bulimia nervosa. Deram (2014) assegura que as dietas, de 
cunho restritivo apresentam um risco altíssimo de desenvolver bulimia nervosa, além de interferir prejudicialmente na saciedade da pessoa que se submete a tal situação.

Outro fator interessante é que a industrialização da alimentação promoveu a concepção de que as empresas devem cozinhar para o consumidor, propondo-lhe ainda a inserção de alimentos light $e$ diet, se incumbindo também do regime dos indivíduos (FISCHLER, 1998). Em alguns casos, o alimento pode significar status para se estabelecer estereótipos, variando entre diversas determinações sociais, sejam elas culturais e/ou financeiras. Assim o produto alimentício a ser consumido configura-se em um símbolo que se revela como estrutura de comunicação entre os indivíduos (COSTA, 2009).

É notório que a mídia tem um controle imponente perante as escolhas alimentares da sociedade e, em geral, cria-se toda uma dinâmica para favorecer a venda de produtos considerados práticos ao consumidor. Desta forma, a educação alimentar deve estar constantemente presente no ambiente escolar em diversas situações sociais e ações educativas que busquem promover a formação de hábitos alimentares saudáveis. É necessário que se problematize o conteúdo, para que o aluno possa refletir acerca de suas escolhas alimentares, e consequentemente vir a se tornar mais crítico em relação às questões que envolvem sua saúde.

\subsection{A Formação de Hábitos Alimentares Saudáveis}

Conceituar e promover uma explanação apropriada a respeito da formação adequada de hábitos alimentares considerados saudáveis é de fato complexo, posto que essa questão seja particular de cada individuo. Todavia, neste tópico será discutido o entendimento definido por estudiosos na área.

Em 2014, o Ministério da Saúde divulgou o Guia Alimentar para a População Brasileira, neste documento é proposto dez passos que embasam a formação da alimentação adequada e sustentável. O sentido sustentável neste caso envolve o contexto agroindustrial no Brasil, no qual se enquadra o uso exacerbado de agrotóxicos, a intensa mecanização e alto consumo de água e combustível (BRASIL, 2014b): 
1. Fazer de alimentos in natura ou minimamente processados a base da alimentação.

2. Utilizar óleos, gorduras, sal e açúcar em pequenas quantidades ao temperar e cozinhar alimentos e criar preparações culinárias.

3. Limitar o consumo de alimentos processados.

4. Evitar o consumo de alimentos ultraprocessados.

5. Comer com regularidade e atenção, em ambientes apropriados e, se mpre que possível com companhia.

6. Fazer compras em locais que ofertem variedades de alimentos in natura ou minimamente processados.

7. Desenvolver, exercitar e partilhar habilidades culinárias.

8. Planejar o uso do tempo para dar à alimentação o espaço que ela merece.

9. Dar preferência, quando fora de casa, a locais que servem refeições feitas na hora.

10. Ser crítico quanto a informações, orientações e mensagens sobre a alimentação veiculadas em propagandas comerciais.

As considerações mencionadas no guia mostram-se favoráveis às dimensões sociais e psicológicas da alimentação e a acepção nutricional é um complemento para reforçar ou adquirir hábitos alimentares saudáveis.

Vasconcelos e Gewandsznajder (1986) assinalam que uma boa alimentação envolve a criticidade relativa ao tema em razão da condição intransigente da mídia na formação dos hábitos alimentares, de acordo com os autores "consumimos certos alimentos não pelo bem que fazem à nossa saúde, mas para satisfazer necessidades criadas pela publicidade" (p. 75).

A nutricionista Strürmer (2002), enfatiza que os alimentos são ferramentas diretas e eficazes para o tratamento e prevenção de várias doenças, por conseguinte é essencial valorizar alimentos considerados funcionais, que são classificados em três grupos: alimentos com propriedades imunomodulatórias, alimentos com atividade antioxidante e alimentos ricos em ácidos graxos poli-insaturados Ômega-3 e Ômega-6.

Pollan (2008) aponta a importância de se alimentar, sobretudo de vegetais, o autor realça que hoje há um complexo nutricional elevado, ou seja, construiu-se uma ideologia em volta da nutrição gerando uma série de mitos. Frente essas condições, é existente uma vasta quantidade de alimentos que garantem trazer inúmeros benefícios à 
saúde abarcando apenas a questão biológica, no entanto comer integra a sociabilidade e a relação com o mundo natural, além de expressar a identidade de cada sujeito.

Para Savioli (2014) a alimentação saudável corresponde ao equilíbrio físico, mental e emocional. A autora abaliza que os alimentos consumidos atualmente são fornecidos por indústrias que prezam unicamente pelo lucro ao invés da saúde da população, portanto a alimentação saudável associa-se a ingestão de alimentos provindos de meios naturais, livres de aditivos e agrotóxicos.

Rodrigues (2011) no Guia de Promoção da Alimentação Saudável e Sustentável para Escolas também informa dez passos que podem fornecer uma boa alimentação, contudo este não se mostra flexível em suas ações, por ser um guia escolar de promoção à alimentação coerente é necessário considerar o contexto que os educandos se inserem e valorizar as suas preferências alimentícias, assim como os aspectos já mencionados neste estudo. As considerações feitas no documento são estabelecidas a seguir:

1. Consumo de hortaliças e frutas.

2. Consumo de feijão, ao menos quatro vezes por semana.

3. Moderar o consumo de alimentos gordurosos.

4. Redução do sal na alimentação.

5. Não deixar de se alimentar.

6. Reduzir o consumo de alimentos que são ricos em açúcares.

7. Não fazer a ingestão de álcool e refrigerantes.

8. Comer de maneira tranquila em um ambiente harmonioso.

9. Manter o peso dentro dos limites saudáveis.

10. Praticar exercícios no mínimo 30 minutos diários.

Compreende-se neste estudo que a perspectiva nutricional é altamente valorosa, entretanto a direção da proposta envolve particularmente, a alimentação sob as perspectivas social, histórica, psicológica e cultural. Logo, prezou-se por considerar a história que os alunos trazem consigo composta de sua cultura e de seu meio social, com a finalidade de discutir a atuação do professor e da escola no campo da educação alimentar. Tunes, Taca e Bartholoto (2005, p. 690) reforçam que "no convívio social, a experiência interpessoal possibilita o processo de elaboração e reelaboração de sentidos que organizam e integram a atividade psíquica dos participantes da relação". 


\subsection{O Papel do Professor e da Escola na Educação Alimentar}

A educação alimentar como prática saudável não se resume ao propósito de simplesmente expor conteúdos e explanar informações, mas se relaciona à conexão das vivências e hábitos que evitem a contração de doenças geradas pelas escolhas alimentícias, uma vez que a prática alimentar ultrapassa as questões puramente biológicas entrando no campo dos assuntos sociais e culturais (DOMENE, 2008; GAVIDIA, 2009). Entretanto, a realidade encontrada nas escolas, como mencionado por diversos autores, é que esse assunto é pouco difundido e delimitado por uma série de fatores, como a ausência de subsídios na formação inicial de professores, o que ocasiona o impedimento de uma abordagem mais proveitosa do assunto. (MOHR; SCHALL, 1992; ZANCUL; GOMES, 2011).

Para Gazzinelli et al (2005), o princípio de educar para a saúde origina-se da concepção de que vários problemas de saúde estão vinculados às condições precárias relacionadas a educação, necessitando, deste modo, de ações que provejam subsídios corretivos e/ou educativos que promovam o bem estar e a boa qualidade de vida. Para os autores os projetos de educação para saúde devem intervir de maneira que os indivíduos tenham autonomia em relação a suas escolhas alimentares.

A educação em saúde na escola deve estar presente em todos os aspectos, desde o ambiente em que o educando está inserido até as intervenções feitas pelo professor na sala de aula, já que muitos fatores físicos, emocionais e sociais podem influenciar de forma desfavorável para a promoção da saúde (MARCONDES, 1972).

Quando se trata da educação alimentar como tema gerador no ensino o papel da escola e do professor abrange diversos aspectos. Tornar a educação associada a um desígnio de sensibilização relativa a uma alimentação saudável, é uma incumbência desafiadora para os profissionais que irão atuar com essa proposta, posto que a formação de hábitos alimentares envolve as vivências diárias que muitas vezes estão arraigadas à formação cotidiana do indivíduo. A ação do professor deve considerar as características peculiares dos discentes, reconhecendo suas experiências sociais acumuladas ao longo do tempo (BULGRAEN, 2010). Delizoicov, Angotti e Pernambuco (2007, p. 152) ressaltam que: 
[...] o professor é, na sala de aula, o porta-voz de um conteúdo escolar, que não é só um conjunto de fatos, nomes e equações, mas também uma forma de construir um conhecimento específico imbuído de sua produção histórica e de procedimentos próprios. Como principal porta-voz do conhecimento científico, é o mediador por excelência do processo de aprendizagem do aluno.

Segundo Gavidia (2009) a consciência social dos professores em relação à educação para à saúde envolve a concepção de que o assunto deve ser abordado a partir do propósito que envolve a modificação ou reforço de hábitos alimentares, no entanto é preciso que o ambiente e as ações pedagó gic as sejam promissores para a apropriação do conhecimento.

De acordo com essa perspectiva, o processo educacional configura-se em uma ação que privilegia a formação do perfil do cidadão que reflete acerca de suas práticas e atitudes, além de favorecer a construção de condições que transformem a realidade do indivíduo (BARBOSA et al, 2012). Driver et al (1999, p. 31) corroboram que, "na educação em ciências, é importante considerar que o conhecimento científico é, ao mesmo tempo, simbólico por natureza e socialmente negociado", ou seja, os indivíduos são letrados cientificamente e tecnologicamente quando possuem autonomia em suas decisões. Costa (1999, p. 14) afirma em relação ao papel das instituições escolares que:

A escola não pode continuar a ser apenas um local de instrução, mas tem de ser também um local onde se personaliza, socializa e educa. Este papel não pertence somente à família. A Escola tem de ser um local de diálogo onde os jovens possam participar de uma forma empenhada e alegre no seu projeto educativo.

A escola, em sua totalidade, deve atuar para que haja a consolidação de propostas pedagógicas que proporcionem uma nova visão de mundo aos seus aprendizes. Porém, não são todas as instituições que fornecem processos educativos que colaborem para essa construção, em muitos casos o professor torna-se inibidor da curiosidade, desfavorecendo o desenvolvimento da autonomia e de outros fatores como a criatividade e o pensamento crítico reflexivo (ALENCAR, 2002).

Nesse sentido, ao transpor a temática da educação alimentar para a escola, pautada principalmente nas premissas da autonomia, Barbosa et al (2012, p. 940) afirmam que, "não se pode desenhar somente uma prática centrada na relação alimentos e seus nutrientes". Sendo assim, a intervenção pedagógica deve envolver um contexto mais amplo de alimentação, abordando as questões culturais e sociais. Partindo desse 
pressuposto, Gomes e Fonseca (2013, p. 3) destacam que, para que a educação alimentar e nutricional seja efetiva e tenha participação ativa do aluno é necessário que haja:

[...] a associação do saber popular ao saber científico, construindo espaço para a troca de experiências, va lorizando uma alimentação que seja capaz de unir saúde e prazer, sem, contudo, deixar de problematizar crenças, mitos e tabus. Neste espaço não haveria transmissão de informações e sim uma construção coletiva de conhecimentos e significados, no qual todos os envolvidos podem aprender e ensinar.

Para Mohr e Schall (1992) a formação do professor para atuar nos domínios da educação para saúde possui um enorme déficit, que é oriundo da falta de conhecimentos teóricos ou práticos acerca de procedimentos didáticos que possam ser desenvolvidos conforme a realidade dos estudantes. Tunes, Tacca e Bartholo (2005) corroboram que as estratégias de ensino devem se aproximar da forma de pensar do aluno, as ações planejadas pelo professor precisam objetivar o desenvolvimento e aprendizagem do educando, de tal modo que a significação dos temas poderá ocorrer a partir da valorização da singularidade de cada indivíduo.

Segundo Yokota et al (2010, p. 39) "a promoção da alimentação saudável no ambiente escolar parte de uma visão integral e multidisciplinar do ser humano", que considera os estudantes como seres singulares, visando fortalecer a formação de valores, de condições sociais e os estilos de vida que contribuam para melhorias da saúde individual e coletiva e do desenvolvimento humano.

As questões inerentes à educação alimentar precisam estar constantemente presente no âmbito escolar, e para que tal ação se torne palpável, a intervenção do professor é crucial. Para Freire (2011b), o educador precisa ter a humildade de reconhecer suas falhas, sem que haja a ânsia de se impor de forma superior. O fato enfatizado pelo autor é que ninguém educa ninguém, o que existe é uma comunicação de saberes relativos que circundam com os demais e com o mundo. 


\section{OBJETIVOS}

\subsection{Objetivo Geral}

Produzir uma Unidade Didática a respeito de educação alimentar na escola, desenvolvendo subsídios que auxiliem a intervenção pedagógica de forma interdisciplinar englobando principalmente aspectos químicos e biológicos e a contextualização nas perspectivas sociais, culturais, emocionais que se relacionam à temática.

\subsection{Objetivos Específicos}

- Realizar um estudo diagnóstico sobre dietas alimentares com adolescentes.

- Propor uma estratégia didática que mobilize os estudantes a questionarem o papel da mídia na formação dos hábitos alimentares.

- Aplicar e avaliar a Unidade Didática produzida. 


\section{METODOLOGIA}

A análise deste estudo foi de natureza qualitativa, ancorando-se em uma interpretação sistemática dos dados. Segundo Bulmer (1977) "a pesquisa qualitativa é utilizada para interpretar fenômenos, que ocorre por meio da interação constante entre a observação e a formulação conceitual, entre a pesquisa empírica e o desenvolvimento teórico, entre a percepção e a explicação". Portanto, compõe-se uma alternativa apropriada de investigação, quando se procura explorar o objeto de estudo, principalmente quando há um interesse específico na interpretação do respondente em relação as suas condutas, motivos e anseios. Martins (2000, p. 58) corrobora que:

$\mathrm{Na}$ pesquisa qualitativa descreve-se e determina com precisão conceitual rigorosa a essência genérica da percepção ou das espécies subordinadas, como a percepção da coisalidade etc. Mas a generalidade mais elevada está na experiência em geral, no pensamento em geral, e isto torna possível uma descrição compreensível da natureza da coisa.

A proposta metodológica caracteriza-se ainda como uma pesquisa-intervenção. Rocha (2003, p. 67) corrobora que:

O processo de formulação da pesquisa-intervenção aprofunda a ruptura com os enfoques tradicionais de pesquisa e amplia as bases teórico-metodológicas das pesquisas participativas, enquanto proposta de atuação transformadora da realidade sócio-política, já que propõe uma intervenção de ordem micropolítica na experiência social.

Na pesquisa-intervenção busca-se investigar a vida dos participantes de maneira qualitativa, com o intuito de gerar ações que estabeleçam um vínculo significativo entre o sujeito e o objeto. Deste modo, a pesquisa realizada neste trabalho relaciona-se com a aplicação de um questionário inicial para 20 adolescentes que estavam cursando séries distintas do Ensino Médio. A partir das considerações coletadas e analisadas desenvolveu-se um material didático que é constituído por dez atividades de ensino que visam problematizar a educação alimentar. Em um segundo momento, a Unidade Didática elaborada foi implantada com outros 21 alunos que cursavam o $8^{\circ}$ ano do Ensino Fundamental, objetivando a valiar o impacto e interação das estratégias de ensino com o referido público. Ao final da aplicação da proposição os mesmos discentes 
responderam a um questionário final e posteriormente, tiveram a oportunidade de participar do V Circuito de Ciências e da Semana Nacional de Ciência e Tecnologia.

\subsection{Instrumentos de Investigação}

\subsubsection{Questionário Inicial e Participantes}

O questionário inicial (Apêndice A) foi aplicado para 20 estudantes de uma escola pública situada na cidade de Planaltina, região administrativa do Distrito Federal localizada a 38 quilômetros de distância de Brasília. A aplicação foi feita pela pesquisadora na data (06 de outubro de 2014) e horário (período matutino) disponibilizados pela professora de Biologia regente na instituição.

Os discentes encontravam-se cursando uma das três séries do Ensino Médio e pertenciam a turmas distintas. O questionário proposto teve o intuito de conhecer a percepções destes participantes a respeito de dietas alimentares.

O questionário configura-se em um método de investigação com perguntas definidas que irão proporcionar dados que poderão identificar características de uma determinada população, obtendo "informações sobre conhecimentos, crenças, sentimentos, valores, interesses, expectativas, aspirações, temores, comportamento presente ou passado etc" (GIL, 2008, p. 121).

O questionário foi estruturado por questões fechadas e abertas. Nas questões fechadas pede-se que os participantes escolham a alternativa adequada a sua percepção. Já as perguntas consideradas abertas permitem que o entrevistado responda de maneira discursiva sobre as concepções que contém (GIL, 2008; LAVILLE; DIONNE, 1999).

$\mathrm{O}$ roteiro de questões para os alunos está baseado nas seguintes considerações, elaboradas pelos pesquisadores deste estudo:
a) Entendimento acerca das dietas.
b) Histórico de realização de alguma dieta.
c) Se o participante já fez alguma dieta.
d) Fonte que o aluno busca informações sobre o assunto. 
e) Acesso a informações de aspectos inerentes as dietas alimentares na escola e, em qual disciplina que o tema foi ministrado.

f) Percepção acerca dos benefícios das dietas para a saúde.

\subsubsection{Questionário Final e Participantes}

O questionário final (Apêndice B) foi aplicado após a intervenção educativa realizada com o auxílio da Unidade Didática. O seguinte instrumento de investigação foi desenvolvido e a aplicado com a perspectiva de conhecer a opinião dos alunos sobre as atividades inseridas no material didático, sendo assim o eixo norteador foram os seguintes questionamentos:

a) Desenvolvimento das aulas com intervenção do material didático.

b) Aprendizagem em relação ao assunto.

c) A educação alimentar partindo das vertentes históricas, culturais, sociais e psicológicas.

d) Estratégias de ensino como subsídio para a motivação e interesse.

O público para qual o questionário foi aplicado foi composto de estudantes do $8^{\circ}$ ano do Ensino Fundamental de outra escola localizada na cidade de Planaltina - DF, estes alunos possuíam até o momento faixa etária de 13 a 15 anos de idade. Inicialmente apresentou-se para a escola a carta de aceite institucional (Apêndice C), e em seguida foram selecionados três alunos de sete turmas do referido ano e mediante ao aceite e autorização dos responsáveis desenvolveu-se a aplicação das atividades de ensino da Unidade Didática. 


\subsubsection{Observações}

As observações ocorreram durante a aplicação das atividades propostas na Unidade Didática para os alunos do $8^{\circ}$ ano do Ensino Fundamental. No decorrer da concretização das ações realizaram-se anotações sistematizadas acerca das considerações feitas pelos estudantes.

A técnica de observação utilizada foi a participante, pois houve a integração da pesquisadora com ao grupo (LAVILLE; DIONNE, 1999). A observação revelou-se como um meio relevante para o processo de investigação neste estudo, uma vez que envolveu o contato direto com os sujeitos participantes.

\subsection{Processo de Construção das Informações}

A pesquisa desenvolvida neste trabalho foi composta por três etapas, primeiramente realizou-se um estudo diagnóstico, focalizando conhecer a compreensão que os alunos possuem acerca das dietas alimentares. A concretização desta etapa aconteceu a partir da aplicação dos questionários mencionados anteriormente. No que se remete a esse primeiro momento, 20 alunos de uma determinada escola situada em Planaltina DF, foram convidados pela pesquisadora para o preenchimento do questionário, posteriormente eles foram informados do objetivo da pesquisa e da possibilidade de recusa e desistência. Além disso, as dúvidas sobressalentes relativas à pesquisa foram esclarecidas por meio do Termo de Consentimento Livre Esclarecido (Apêndice D), que foi assinando por aquele que concordou em participar da pesquisa.

A segunda etapa consistiu na produção de uma Unidade Didática, que foi construída a partir das respostas fornecidas pelos educandos participantes do estudo. Por fim, a última parte deste estudo, configurou-se na aplicação das atividades inseridas no material produzido, ocorrendo o desenvolvimento com outros 21 alunos do $8^{\circ}$ ano do Ensino Fundamental, de uma escola também localizada na cidade de Planaltina - DF, para estes educandos também foi aplicado um questionário final que pretendeu conhecer o impacto das propostas em relação ao seu interesse e motivação inerentes ao assunto 
tratado. Após a efetuação destas etapas ocorreu ainda à divulgação dos conhecimentos apropriados pelos alunos no V Circuito de Ciências e na Semana Nacional de Ciência e Tecnologia.

A justificativa da aplicação dos questionários inicial e final para diferentes grupos de adolescente relaciona-se com a concepção de que o educador pode aplicar as proposições para discentes de distintos níveis da Educação Básica. Além disso, os dados do questionário prévio visaram embasar as atividades da Unidade Didática para que assuntos abordados tivessem maior proximidade com a realidade dos adolescentes, independente da faixa etária.

\subsection{Proposição Educativa}

A aplicação das atividades didáticas aconteceu no $3^{\circ}$ bimestre letivo de 2015, duas vezes por semana em uma escola da Rede Pública de Ensino, situada em Planaltina - DF, totalizou-se 10 encontros e 20 horas de duração. Para o desenvolvimento das atividades, os 21 alunos participantes do $8^{\circ}$ Ensino Fundamental, compareceram no período inverso de aula. Optou-se por abordar a proposição no período contrário de regência, devido à variante de tempo disponível para trabalhar com todas as turmas.

Em momento posterior aos encontros, os estudantes participantes tiveram como tarefa apresentar as atividades propostas para o restante da turma, organizando o conhecimento apropriado e expondo-o por meio das produções (cartazes, murais, etc.) realizadas nos encontros.

As atividades não foram aplicadas integralmente nas turmas, devido os conteúdos curriculares a serem abordados e o tempo decorrente para tal. Para a conclusão da avalição da Unidade Didática foram aplicados questionários para avaliar as atividades aplicadas. Para auxiliar na coleta de dados nesta etapa foram realizadas observações sistemáticas e gravações em áudio.

A Unidade didática proposta por este trabalho integra a abordagem principalmente de assuntos que englobam as dietas alimentares e a influência da mídia na formação de hábitos alimentares. Essa proposição educativa é destinada para o público adolescente, sendo este um recurso que poderá auxiliar o professor nas aulas 
que envolverão a temática em questão. Assim, as atividades elaboradas possuem os seguintes tópicos: assunto da aula, objetivos, descrição da atividade de ensino, materiais necessários e avaliação. É valido ressaltar que algumas destas atividades foram inspiradas em outros trabalhos, já as demais foram elaboradas pela pesquisadora. 


\section{RESULTADOS}

Com o intuito de facilitar a compreensão e descrever com maior fidedignidade os dados coletados, os resultados alcançados nesse estudo serão apresentados a partir de quatro vertentes: I. Questionário Inicial, II. Proposição educativa, III. Questionário Final e IV. Circuito de Ciências e Semana Nacional de Ciência e Tecnologia.

\subsection{Questionário Inicial}

A aplicação do questionário inicial contou com participação de vinte estudantes cursistas do nível Médio da Educação Básica de uma escola localizada em Planaltina, região administrativa do Distrito Federal. Estes educandos foram selecionados pela professora de Biologia da referida instituição. $O$ objetivo deste instrumento metodológico inicial foi identificar as percepções dos discentes a respeito das dietas alimentares no seu cotidiano, para que assim ocorresse a elaboração de uma Unidade Didática.

Os participantes do questionário inicial possuíam a oscilação de faixa etária de16 a 24 anos de idade, a tabela 1 enfatiza essa característica:

Tabela 1. Faixa de idade dos participantes do questionário inicial.

\begin{tabular}{|c|c|}
\hline Idade & Alunos \\
\hline $\mathbf{1 6}$ & 5 \\
\hline $\mathbf{1 7}$ & 7 \\
\hline $\mathbf{1 8}$ & 4 \\
\hline $\mathbf{1 9}$ & 2 \\
\hline $\mathbf{2 3}$ & 1 \\
\hline $\mathbf{2 4}$ & 1 \\
\hline
\end{tabular}


Em relação ao entendimento dos estudantes acerca das dietas alimentares, esses realizaram as colocações a seguir. Para manter o sigilo em relação à identidade dos participantes será utilizado o sistema de numeração para diferenciá-los.

"Dieta é um método para ter uma saúde equilibrada e alguns casos perda ou ganho de peso" (Aluno 2)

"Dieta é tudo aquilo que comemos" (Aluno 6)

"Fazer dieta é ter uma alimentação saudável para emagrecer e para ter uma boa qualidade de vida" (Aluno 7)

"Dieta são mudanças na alimentação para torná-la saudável" (Aluno 8)

"Dieta é uma maneira de emagrecer" (Aluno 10)

"São regras a serem seguidas para obter uma boa alimentação e perda de peso" (Aluno 12)

"Dieta é uma formulação alimentar com o objetivo de emagrecer e/ou melhorar a saúde" (Aluno 15)

"As dietas ajudam a diminuir o peso e a melhorar a circulação sanguínea" (Aluno 20)

As respostas realçadas pelos estudantes denotam que as dietas estão relacionadas com a perda de peso e consequentemente este fator promove uma boa qualidade de vida e melhores condições de saúde.

Sobre a prática de fazer dietas alimentares 55\% dos participantes relataram nunca ter feito e os demais $45 \%$ dos discentes enfatizaram ter realizado objetivando o ganho de massa muscular e a perda de peso. Destes nove estudantes, que englobam os 45\% mencionado, apenas três procuraram o acompanhamento de um profissional da área para realizar a dieta alimentar.

Quando questionados se conheciam algum tipo de dieta $65 \%$ relatou que "sim" e os outros 35\% ressaltou não conhecer. Aos que destacaram a resposta "sim" como opção foi solicitado que mencionassem a dieta que tinham conhecimento, a tabela 2 demonstra as considerações feitas pelos discentes a esse respeito: 
Tabela 2. Dietas alimentares que os participantes possuem conhecimento.

\begin{tabular}{|c|c|}
\hline Tipo de Dieta & Quantidade de Alunos \\
\hline Dieta de carboidratos e proteínas & 5 \\
\hline Dieta do chá & 1 \\
\hline Dieta do ovo & 1 \\
\hline Dieta do leite & 1 \\
\hline Dieta da maçã & 1 \\
\hline Dieta hipossódica & 1 \\
\hline Dieta da água & 1 \\
\hline Dieta do biscoito de sal & \\
\hline
\end{tabular}

Os participantes também foram indagados acerca das fontes de informações que costumam utilizar para buscar conhecimentos sobre o tema, a tabela 3 evidencia os principais veículos de pesquisa empregados pelos alunos:

Tabela 3. Fonte de informações que os alunos utilizam para pesquisar sobre alimentação.

\begin{tabular}{|c|c|}
\hline Fonte de Informação & Quantidade de Alunos \\
\hline Internet (sites e redes sociais) & 15 \\
\hline Televisão & 3 \\
\hline Nutricionista & 3 \\
\hline Revistas & 3 \\
\hline Amigos & 1 \\
\hline Livros & 1 \\
\hline Nunca pesquisou a respeito & 1 \\
\hline Não destacou nenhuma opção & \\
\hline
\end{tabular}

As alternativas salientadas pelos estudantes mostram que a internet é o principal meio de pesquisa utilizado por eles, por apresentar provavelmente fácil acesso e a vasta disponibilidade de dietas alimentares a serem aderidas. Para essa questão os alunos puderam escolher mais de uma opção da pesquis a comumente utilizada, sendo assim são destacados principalmente a procura por nutricionistas, revistas, televisão e amigos que costumam realizar dietas. 
Para identificar se o tema tem sido abordado na escola, os discentes foram questionados se lembram de ter estudado acerca das dietas em alguma disciplina, a tabela 4 representa as considerações feitas:

Tabela 4. O estudo das dietas alimentares na escola.

\begin{tabular}{|c|c|}
\hline Opção & Quantidade de Alunos \\
\hline Sim & 7 \\
\hline Não & 13 \\
\hline
\end{tabular}

Dos vinte estudantes participantes no preenchimento do questionário inicial, apenas sete relatam ter estudado a temática na escola na disciplina de Educação Física. Os dados obtidos mostram que apesar da educação alimentar ser um assunto transversal, que possibilita a abordagem interdisciplinar essa questão não é abordada no ambiente escolar.

A última questão proposta no questionário inicial envolveu a percepção dos educandos sobre os benefícios das dietas alimentares, 90\% dos alunos disseram que as dietas alimentares são promotoras da saúde dos indivíduos, as respostas abaixo confirmam estes dados:

"As dietas contribuem para o bom funcionamento do corpo e dos órgãos, na vitalidade, ganho balanceado de peso e energia" (Aluno 2)

"Elas evitam doenças e conservam a boa forma" (Aluno 5).

"Uma dieta saudável favorece o bem-estar e uma vida melhor" (Aluno 6)

"Fazer dieta frequentemente traz melhor desempenho na realização de atividades físicas" (Aluno 12)

"Elas são benéficas, pois ajudam a controlar a obesidade" (Aluno 14)

"As dietas ajudam na redução de gordura e no melhoramento do organismo" (Aluno 15)

"Uma dieta acompanhada de um nutricionista pode trazer muitos benefícios" (Aluno 19)

Apenas $10 \%$ dos alunos relatam não saber a funcionalidade das dietas. As respostas obtidas retornam novamente para a concepção de que as dietas alimentares colaboram para um perfil estético estabelecido, além de contribuir para uma vida 
saudável livre de complicações advindas da má alimentação, nota-se que para os participantes o ato de praticar dietas regulamente por si só já é saudável.

A partir das considerações salientadas no questionário inicial, foram elaborados tópicos para se abordar na Unidade Didática, sendo eles: conhecendo os alimentos, os alimentos no cotidiano, a relação dos alimentos com os fatores sociais, a alimentação e as contribuições culturais, situações problemas envolvendo as dietas alimentares e a influência das mídias nas dietas alimentares. Além destes assuntos inseriu-se também: o consumo de fast foods e os transtornos alimentares, uma vez que esses estão intrinsicamente ligados à temática em questão.

\subsection{Relato da Proposição Educativa}

A proposta de ação educativa relacionou-se com a elaboração de uma Unidade Didática, com o intuito de auxiliar os professores na abordagem do assunto no âmbito escolar.

Para avaliar as atividades descritas no material, todas as propostas foram aplicadas para 21 discentes que estavam cursando o $8^{\circ}$ ano do Ensino Fundamental em uma escola da rede pública de ensino, situada na cidade Planaltina, Distrito Federal. Os alunos envolvidos nesta ação possuíam a faixa etária de 13 a 15 anos de idade.

Objetivando realizar a ação pedagógica foi proposta a realização de um minicurso no horário inverso de aula para os educandos interessados, já que a aplicação integral em todas as turmas interferiria no andamento dos conteúdos curriculares. A ação foi desenvolvida em dez encontros com a duração de aproximadamente 2 horas diárias.

O registro da aplicação das atividades aconteceu com auxílio de fotografias, gravações de áudio e observações sistemáticas de cada encontro.

A seguir serão expostos de forma sucessiva os relatos dos encontros e percepções dos alunos acerca de cada atividade desenvolvida na Unidade Didática. 


\subsubsection{Atividade 1 - Conhecendo os Alimentos}

Neste primeiro encontro vários alimentos naturais foram levados para a aula (Figura 1) e os alunos tiveram a oportunidade de explorar as formas, texturas, cores, cheiros dos alimentos expostos. Os alimentos utilizados foram: rabanete, abacate, ameixa, kiwi, brócolis, jiló, chuchu, berinjela, agrião, erva doce, hortelã, macarrão, pão, azeite, pepino, quiabo, ervilha, arroz, leite, amendoim e banana. A princípio todos se mostraram curiosos em saber do que se tratava a atividade e logo de início buscaram interagir para relembrar o nome dos alimentos dispostos.

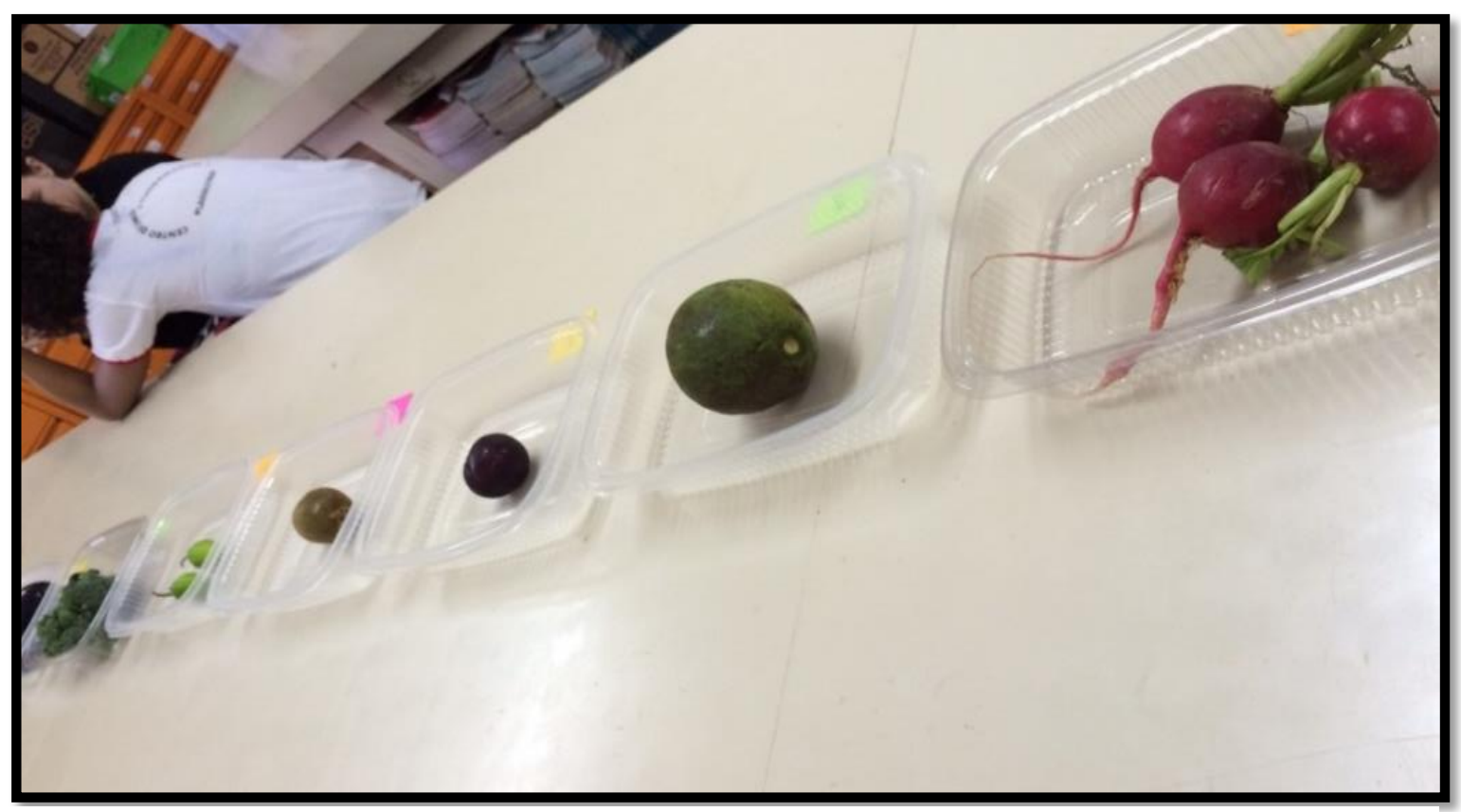

Figura 1. Alimentos expostos para os alunos.

$\mathrm{Na}$ atividade os alunos puderam refletir sobre a vasta quantidade de alimentos naturais e derivados existentes. Visto que com a exposição esses tiveram a oportunidade de salientar suas concepções diante do alimento disposto, destacando principalmente a frequência de consumo e gosto pelo alimento.

Percebeu-se que a maioria dos alunos tiveram dificuldades em identificar o nome dos alimentos e recorreram à ajuda dos demais colegas. Eles enfatizaram que alguns alimentos não estão presentes em seu consumo diário, como por exemplo, o chuchu, jiló, pepino e brócolis. 
Esta proposta inicial visou valorizar os alimentos naturais e identificar se estão inseridos na alimentação diária dos adolescentes. Foi notório com esta atividade, que a alimentação é um tema importante para os discentes e que eles já continham conhecimentos prévios sobre os alimentos apresentados.

\subsubsection{Atividade 2 - Os Alimentos no Cotidiano}

$\mathrm{Na}$ atividade sucessiva de número 2, os discentes tiveram que realizar pesquisas em grupo, sobre músicas, poemas e textos que tinham como temática a alimentação. Sendo assim, os adolescentes foram divididos em grupos para que em seguida pudessem apresentar suas investigações acerca do que foi solicitado. As seleções feitas pelos educandos foram as seguintes (prezando pelo sigilo de identificação participante os alunos serão identificados pelos grupos, seguidos pela numeração de apresentação):

"A alimentação saudável envolve o bem estar, comer com calma e saborear a comida torna esse momento especial e mais feliz!" (Grupo 1)

"Poema da alimentação: Para a gente ter saúde, e sentir-se equilibrada, é necessário que mude uma ou outra coisa errada; Falar de alimentação, que racional deve ser, quer dizer, ter atenção ao que vamos comer. (Grupo 2)

"Meu lanchinho, meu lanchinho, vou comer, vou comer, pra ficar fortinho, pra ficar fortinho e crescer!" (Grupo 4)

"Para saúde ter devemos bem comer; Em maior quantidade os nossos cereais, massa, pão, arroz e muito mais; Frutas e legumes são grupos demais, pois têm nutrientes até não poder mais; Lacticínios tu deves comer seja no almoço ou entardecer; Carne, peixes e ovos energia nos dão; Água no centro para não esquecer, pois é essencial é o que devemos beber; $\mathrm{O}$ resto é bom pouco comer, em grande quantidade mal vai nos fazer" (Grupo 5)

Após este primeiro momento os alunos justificaram suas escolhas, os comentários a seguir relatam esse aspecto:

"Nós escolhemos essa frase, pois envolve o comportamento das pessoas durante alimentação, geralmente as pessoas se alimentam muito rápido e esquecem que comer é um ato importante" (Grupo 1)

"Escolhemos esse poema porque é importante ter uma boa alimentação, ao invés de comer apenas bobagens" (Grupo 2) 
"Escolhemos uma música que lembra nossa infância, desde criança a escola fala sobre a nossa relação com a alimentação" (Grupo 4)

"Optamos por esse poema, porque fala da diversidade de alimentos e também que é importante ter um equilíbrio nos alimentos que comemos" (Grupo 5)

A partir dos discursos dos grupos é notório que os educandos começaram a vislumbrar a alimentação pela perspectiva cultura e social. Durante esta proposta os grupos de alunos tiveram dificuldades relativas à produção do mural, pois não havia espaço disponível na escola para exibição, no entanto os cartazes foram confeccionados e guardados para exposição em um momento posterior.

No decorrer da atividade todos os alunos participaram ativamente e contribuíram para a produção do cartaz (Figura 2), que ademais foi apresentado para as turmas pertencentes a cada grupo.

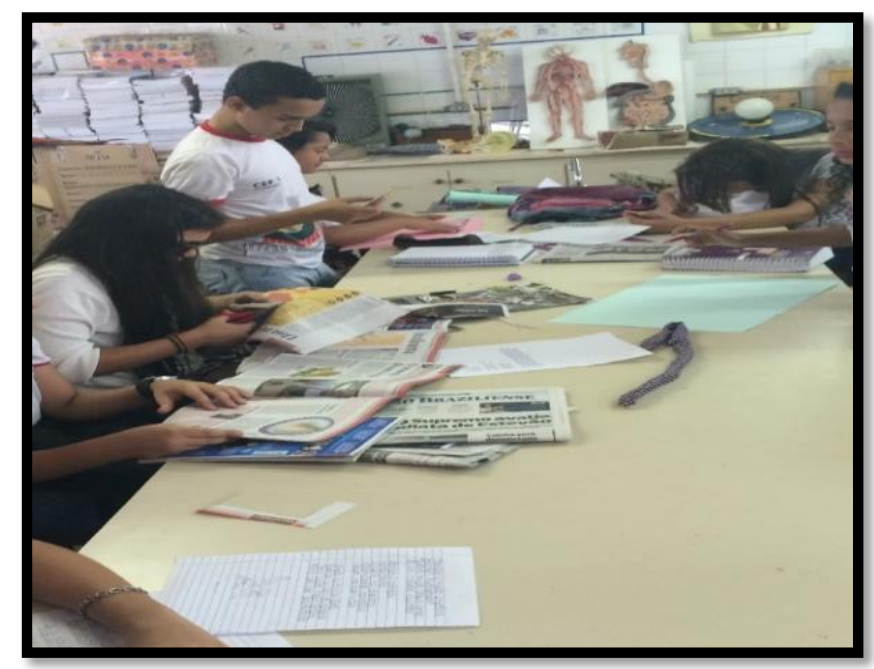

Figura 2. Participantes elaborando cartazes acerca da pesquisa realizada.

\subsubsection{Atividade 3 - A Relação da Alimentação com os Fatores Sociais}

A proposta 3 buscou envolver a relação entre alimentação e o fatores social, com auxílio do texto de divulgação científica "Porque gostamos tanto de comida?" (Anexo A). 
Nesta atividade os alunos foram dispostos em um círculo para que pudessem realizar a leitura e em seguida discutir das principais ideias definidas por eles. Os comentários relatados abaixo esclarecem a percepção dos alunos perante o debate ocorrido:

"A leitura do texto mostrou que a alimentação está envolvida com a evolução da sociedade" (Aluno 9)

"O ato de cozinhar se relaciona com a forma que tratamos os alimentos, porque quando a gente cozinha o alimento fica livre de bactérias, como por exemplo, a carne de porco" (Aluno 11)

"O texto mostra uma visão diferente sobre a alimentação, para mim ela estava relacionada com a obtenção de energia para o organismo" (Aluno 17)

As colocações salientadas pelos discentes destacam principalmente a visão que os alunos possuíam associa-se ao desenvolvimento do organismo e a geração de energia para a realização de atividades diárias. Com a leitura do texto e os comentários enfatizados pode-se observar a construção de novas vertentes em relação ao ato de comer.Após a discussão, os educandos foram divididos em grupos e solicitou-se que se referissem à alimentação por meio de histórias, manifestações culturais e mitos populares em cartazes (Figura 3 e 4 ).

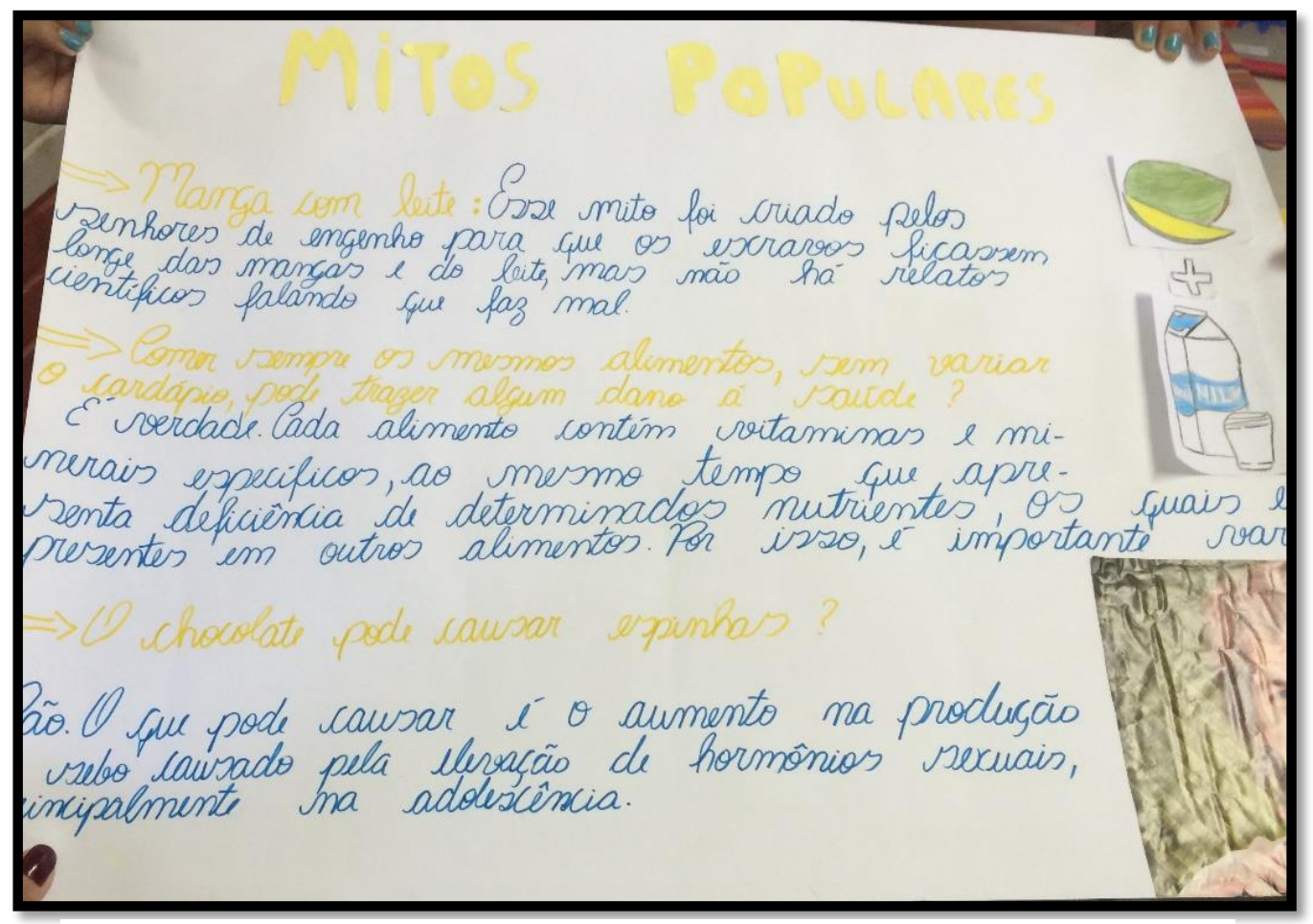

Figura 3. Cartaz produzido pelos participantes (Grupo 3). 


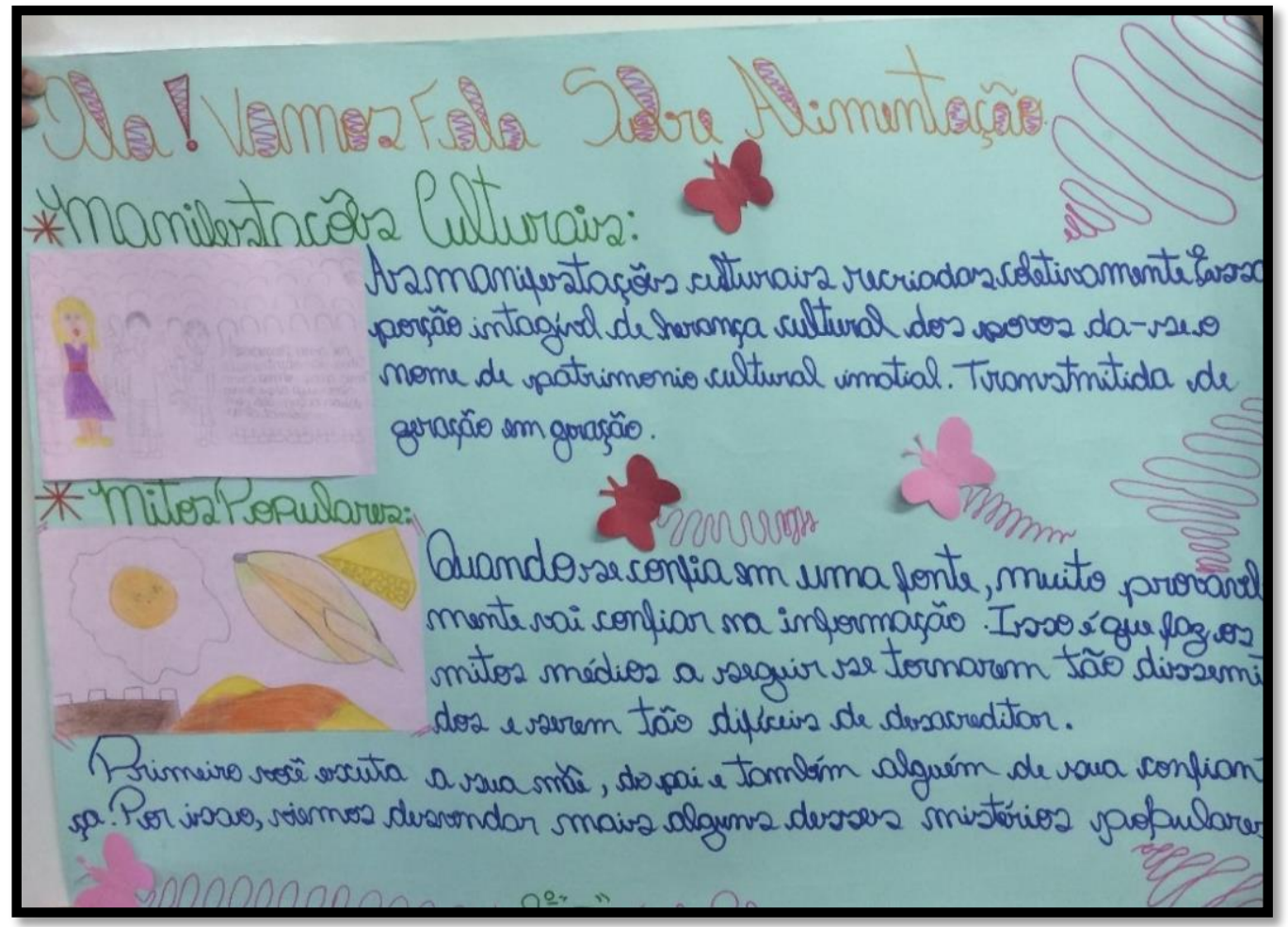

Figura 4. Cartaz produzido pelos participantes (Grupo 4).

Em um momento seguinte, os alunos expuseram suas produções para suas respectivas turmas, explanando as considerações inseridas.

\subsubsection{Atividade 4 - A Alimentação nas Diversas Culturas}

Pretendendo ressaltar e valorizar as questões culturais que envolvem a alimentação foi proposto que os alunos realizassem uma pesquisa sobre a cultura alimentar de diferentes países ou regiões brasileiras. Neste contexto, os discentes foram organizados em grupos para que desenvolvessem a atividade em questão e posteriormente, apresentarem para os demais participantes o resultado de suas investigações.

Essa atividade proporcionou o entusiasmo nos educandos, já que tiveram que preparar o alimento oriundo da região escolhida e expor os aspectos que envolveram a sua produção (Figura 5). 


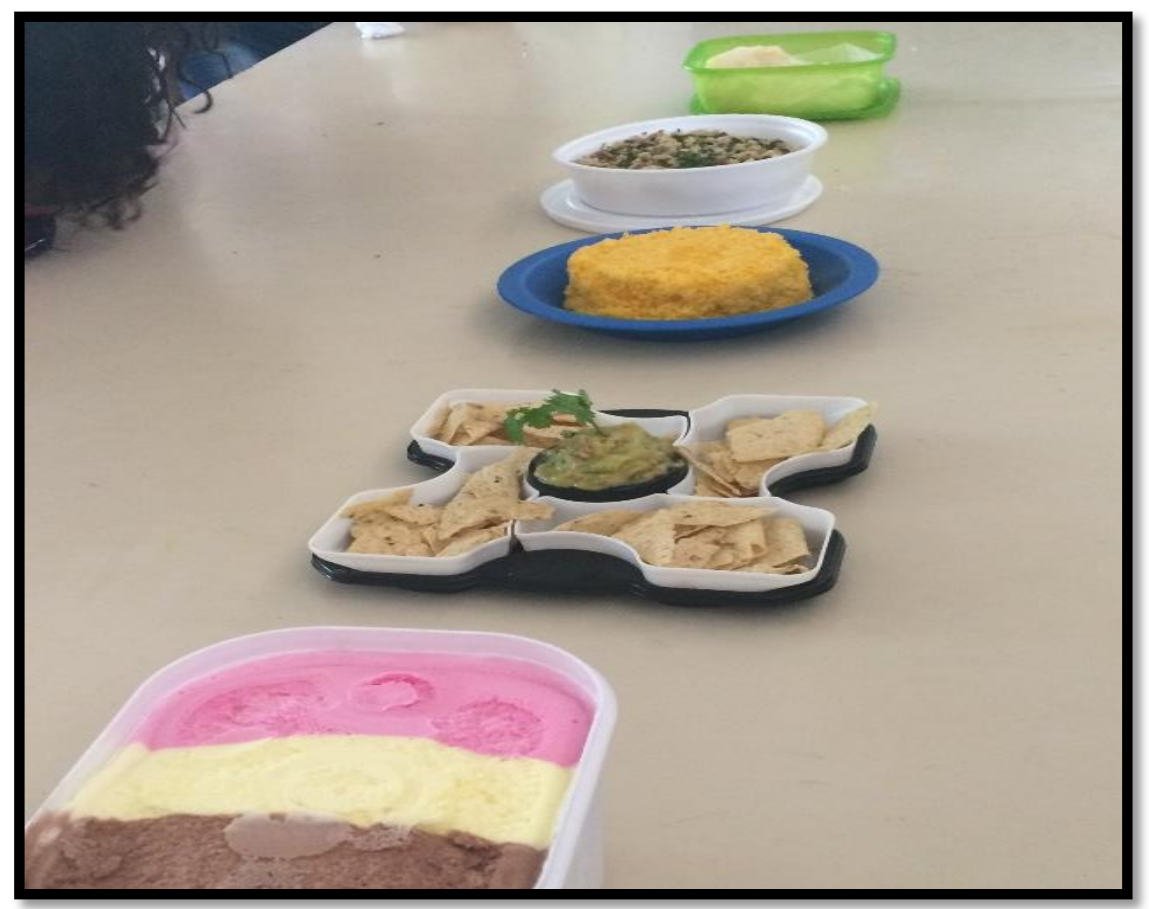

Figura 5. Alimentos escolhidos pelos discentes: Sorvete, guacamole, cuscuz, feijão tropeiro e tapioca.

Após a exposição dos alimentos os alunos foram questionados com a seguinte indagação “A cultura interfere na formação dos hábitos alimentares? Como?" a resposta do educando enfatizada abaixo mostra a compreensão que possui:

"A alimentação é uma construção histórica, existem alimentos como, por exemplo, o sorvete que foi feito inicialmente na china e depois foi levado para países europeus, e em seguida para outros países, como os Estados Unidos. A questão cultural envolve o fato de que o sorvete ficou duzentos anos para ser divulgado para todas as camadas financeiras do mundo, porque antes só a elite tinha a possibilidade de consumir" (Aluno 16)

Os participantes relatam principalmente que a questão cultural está intrinsecamente correlacionada com o fator econômico, e que é evidente que em algumas regiões os indivíduos irão fazer o consumo de determinados alimentos por falta de recursos financeiros.

Durante essa proposta, pode-se notar o empenho dos alunos em pesquisar sobre a comida típica escolhida, observou-se que houve uma preocupação em embasar teoricamente o contexto histórico cultural que envolvia a comida disposta. 


\subsubsection{Atividade 5 - Dietas Alimentares: Situações Problemas}

O tema dietas alimentares é frequente na mídia e está em constante diálogo entre os indivíduos da sociedade. Para abordar esta questão de forma crítica, de modo que os alunos pudessem refletir acerca de suas escolhas alimentares, os participantes foram divididos em três grupos, para realizar a análise de três situações problemas (Apêndice E) que ocasionalmente acontecem no cotidiano, a seguir dispõem-se o relato descrito pelos grupos de alunos:

"Fazer dietas exageradas e rígidas que tiram os nutrientes necessários para o organismo, atrapalha o desenvolvimento da adolescente, então é preciso se alimentar de comidas saudáveis e se exercitar sem exageros" (Grupo 1 - sobre a situação problema 1)

“As dietas restritivas podem trazer vários problemas de saúde, pois precisamos de uma quantia diária de cada nutriente, não é errado fazer exercícios físicos, mas tem que ter moderação" (Grupo 2 - sobre a situação problema 2)

"De acordo com a situação problema que estudamos, as dietas alimentares que são restritivas podem trazer diversos problemas, como anorexia, bulimia e outros transtornos" (Grupo 3 - sobre a situação problema 3)

Nas situações problemas foram inseridos questionamentos que nortearam o discurso dos estudantes, nesta atividade observou-se que os participantes estavam construindo conceitos que envolvem os aspectos psicológicos da alimentação. A consideração do grupo 3 denota a inserção dos transtornos alimentares como fator que pode ser causado em consequência das dietas alimentares restritivas, os demais grupos corroboram primordialmente sobre a esfera nutricional.

Durante a atividade houve a necessidade de explanar sobre os diferentes aspectos das dietas alimentares e como estas podem se caracterizar como restritivas. Para concluir a proposta solicitou-se que os educandos elaborassem cartazes com slogans e frases de impacto sobre a temática trabalhada (Figura 6). 


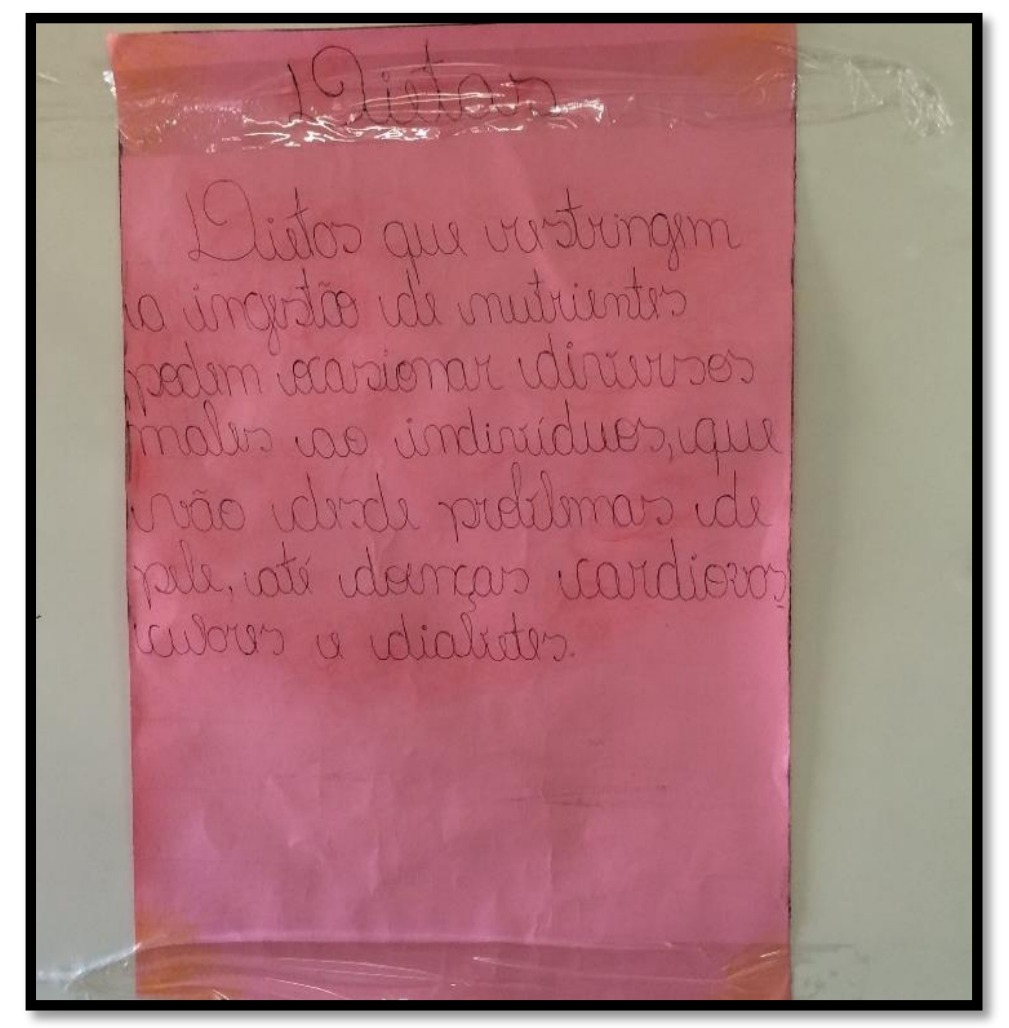

Figura 6. Cartaz sobre dietas alimentares restritivas, produzido pelos alunos (Grupo 3).

A atividade de ensino desenvolvida permitiu que os alunos interagissem com o grupo, expondo suas concepções acerca das dietas alimentares, com as colocações feitas por eles pode-se identificar a percepção que cada um possui sobre o tema. É valido destacar que para a realização dessa ação é preciso compreender o funcionamento das dietas e o que podem ocasionar no organismo de quem as adere.

\subsubsection{Atividade 6 - A Influência da Mídia nas Dietas Alimentares}

Com a proposta de continuar a sequência didática corroborando acerca das dietas alimentares, sugeriu-se que os alunos executassem uma pesquisa sobre as considerações vinculadas à alimentação na mídia, objetivando, posteriormente organizar essas informações e inseri-las em um jornal de divulgação científica. Nesta ação, os discentes foram dispostos em sete grupos para que pudessem elaborar o material em questão. Abaixo serão relatados conceitos embasados pelos alunos no jornal produzido: 
"As pessoas precisam se aceitar do jeito que elas são, e não seguir o padrão que a mídia fala que é ser muito magra, então se uma pessoa é obesa por exemplo, ela vai ser bastante criticada pela sociedade" (Grupo 2)

"As indústrias divulgam alimentos que tem muita gordura, açúcar e sal que são pobres em outros nutrientes, como vitaminas" (Grupo 3)

"A mídia atinge o público infantil que o mais vulnerável com propagandas promocionais de diversos alimentos como: biscoitos recheados, fast food, refrigerantes, etc." (Grupo 5)

"O marketing nutricional busca mostrar os produtos, de uma forma que os consumidores passam se sentir atraídos" (Grupo 6)

Foi notório que a maioria dos grupos deu enfoque ao marketing como o provedor principal da formação dos hábitos alimentares. Percebeu-se também que os alunos destacam a influência de celebridades na propaganda de produtos alimentares, o discurso dos discentes a seguir denota essa questão:

"As pessoas da sociedade desenvolvem um padrão de alimentação e os artistas acabam divulgando uma série de produtos relacionados ao marketing alimentar, como o caso dos suplementos alimentares que a gente vê todos os dias no instagram ou no facebook" (Grupo 7)

Nesta atividade os educandos perceberam a vasta quantidade de informações que são expostas na mídia, e o que ocasionam na formação dos hábitos alimentares dos indivíduos. A partir das colocações salientadas pelos discentes, infere-se que se tornou perceptível para esses a influência da mídia na padronização de beleza, e que para desmistificar esse modelo é preciso selecionar coerentemente os conhecimentos expostos pelos meios de comunicação.

\subsubsection{Atividade 7 - Fast Foods e os Impactos na Saúde Humana}

A atividade referida dividiu-se em dois momentos. A primeira etapa esteve associada à quantidade de açúcar presente nas bebidas industrializadas, assim os participantes tiveram à disposição os materiais para desenvolver a atividade (açúcar, balança, recipientes transparentes e embalagens das bebidas), desta maneira, os estudantes distribuíram o açúcar nos recipientes com auxilio de uma balança (Figura 7). 


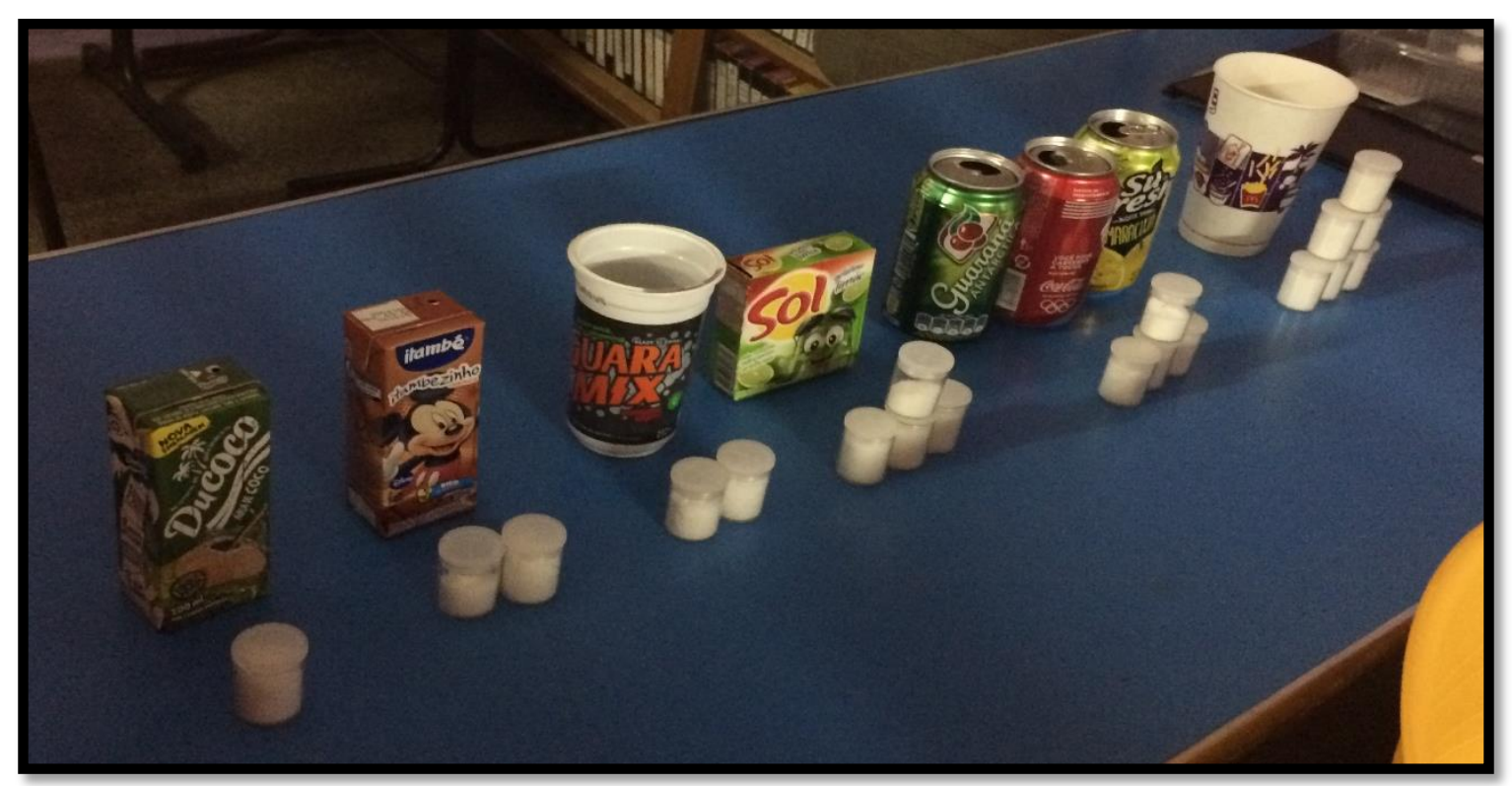

Figura 7. Quantidade de açúcar presente em bebidas industrializadas.

Essa atividade possibilitou a participação ativa dos discentes, uma vez que no momento de separação do açúcar de cada bebida industrializada, esses demostraram entusiasmo e curiosidade. Após a organização do experimento, os educandos observaram a quantidade que cada bebida possuía de açúcar, neste instante foi perceptível o impacto da atividade, principalmente em relação ao refrigerante que contém uma medida exacerbada de açúcares.

Em um segundo momento, os discentes assistiram ao documentário Super Size me - A dieta do palhaço, e em seguida foi solicitado que produzissem um texto relatando suas percepções a partir da exibição do documentário, os trechos descritos abaixo realçam as concepções relatadas:

"A dieta do palhaço, é uma dieta maluca que pode ocasionar até a morte, porque restringiu diversos nutrientes necessários para a saúde do corpo. Comer só fast foods pode ser muito ruim para organismo, a pessoa se prende ao que aparentemente pode ser mais prático naquele momento" (Aluno 1)

"O documentário da dieta do palhaço, foi realizado porque o cineasta que fez a gravação queria mostrar como ele ficaria após comer apenas fast foods por vários dias. Nos Estados Unidos a segunda causa de morte é a obesidade, mais de 400 mil pessoas morrem por ano devido a essa doença e o Brasil segue este modelo, porque as pessoas cada vez mais comem os fast foods" (Aluno 15)

"O documentário Super Size mostrou que comer fast foods todos os dias gerou muitos problemas para a pessoa que fez o experimento, ele ganhou muito peso a quantidade de glicose também aumentou muito e 
também causou impotência sexual, ele ainda poderia ter adquirido câncer de próstata, diabetes, hipertensão e outras doenças" (Aluno 16)

A aplicação da atividade mencionada exibiu uma perspectiva distinta dos fast foods para os alunos, foi evidente a impressão de impacto que tiveram no decorrer das etapas, primordialmente quando se tratou da quantidade de açúcar contido nas bebidas. O que tornou esta atividade diferenciada foi a participação ativa dos estudantes, o fato de realizar os procedimentos propostos os possibilitou a uma postura reflexiva sobre o que consomem no cotidiano.

\subsubsection{Atividade 8 - Diário Alimentar}

Nesta atividade os alunos foram convidados a construir um diário alimentar, no qual tiveram que reportar sua alimentação cotidiana, portanto esta proposta havia sido apresentada desde o início da proposição educativa para que educandos tivessem um tempo maior de anotações.

A análise dos diários mostrou que os participantes comumente fazem as três refeições diárias, e que há grande incidência nos intervalos do consumo predominante de refrigerantes, doces e massas.

Após a entrega dos diários os educandos foram questionados acerca de suas respectivas alimentações, como a seguinte indagação "Você considera sua alimentação saudável?", caso o retorno do aluno se mostrasse negativo, esse deveria salientar quais atitudes seriam cabíveis para torná-la adequada. Algumas das respostas obtidas são descritas a seguir:

'Não é preciso cortar totalmente o açúcar ou a gordura, mas procurar ter um equilibrio no que for comer" (Aluno 5)

"Não tem necessidade de fazer uma dieta, mas procurar comer alimentos naturais, como a gente estudou" (Aluno7)

"Acho que posso evitar as gorduras e os doces e comer mais frutas" (Aluno 9)

"Variar nas comidas, não só comer um tipo de alimentos, mas a quantidade certa de todos os nutrientes" (Aluno 10) 
A atividade foi construtiva para a aprendizagem dos discentes e também conveio de feedback para o professor, já que os alunos compreenderam a importância de ter um equilíbrio nas suas escolhas alimentares, ponto esse mencionado pela maioria. Para finalizar a ação pedagógica foram expostos para os educandos os dez passos para a promoção de uma alimentação adequada e saudável em consonância com o Guia Alimentar para a População Brasileira. A partir desta intervenção os alunos solucionaram a atividade complementar (Apêndice F) contida na Unidade Didática.

\subsubsection{Atividade 9 - Transtornos Alimentares}

Buscando conceituar e discutir a propósito dos transtornos alimentares com os participantes, utilizou-se como embasamento um texto de divulgação científica (Anexo B). Por conseguinte, o artigo foi entregue aos discentes e foi solicitado que realizassem a leitura, destacando os pontos mais relevantes considerados por eles para a discussão do tema, a seguir são expostos alguns relatos:

"Os transtornos alimentares também podem ser influência da mídia né professora? Como no caso da anorexia que a pessoa sempre busca ter um corpo muito magro, que é um padrão que a sociedade coloca" (Aluno 1)

"Quando a pessoa tem obsessão psicológica em relação à alimentação irá gerar problemas biológicos e físicos também, os distúrbios podem trazer várias outras doenças" (Aluno 3)

"Eu não sabia que existia tantos transtornos, esse distúrbio alimentar do sono mesmo que a pessoa come várias coisas durante a noite e não se lembra de nada depois, eu não conhecia" (Aluno 6)

"No nosso meio tem muitas pessoas que tem esses transtornos e às vezes nem sabe, as meninas principalmente" (Aluno 20)

Após a discussão do texto, os educandos foram organizados novamente em sete grupos e foi proposto que elaborassem a construção de cartazes que tornassem visíveis os casos de transtornos alimentares.

A atuação dos alunos, assim como nas demais atividades, foi ativa e houve contribuição de todos na confecção do material. Para finalizar a proposição, foi explanado acerca das formas de prevenção e tratamento dos transtornos alimentares, 
afirmando a importância das escolhas alimentares aderidas, já que essas interferem no funcionamento do corpo como um todo. Nessa penúltima ação foi aplicada a atividade complementar (Apêndice G), um caça palavras sobre os transtornos alimentares, no qual todos os participantes obtiveram êxito.

\subsubsection{Atividade 10 - Compartilhando os Saberes Adquiridos}

A última atividade da sequência didática englobou o compartilhamento de um lanche coletivo. Os alunos se organizaram e elegeram os alimentos a serem consumidos pela turma.

Os alimentos escolhidos e produzidos pelos discentes foram: sanduíche natural, mousse de limão, bolo de cenoura com chocolate, salada de frutas e sucos naturais de laranja e maracujá.

O mais interessante desta atividade foi que todo o lanche disposto foi preparado pelos discentes. Quando questionados a esse respeito, esses ressaltaram que cozinhar e produzir sua própria alimentação também faz parte do bem-estar e saúde do seu organismo.

Para finalizar o módulo de estratégias de ensino em educação alimentar, foi aplicada a atividade complementar (Apêndice H) e visou-se também dialogar sobre as vertentes sociais, culturais, históricas e psicológicas da alimentação buscando refletir acerca das escolhas alimentares diárias.

\subsection{Questionário Final}

O questionário final teve o intuito de buscar subsídios que relatassem a percepção dos alunos acerca das atividades de ensino desenvolvidas. O referido instrumento investigativo foi aplicado após a conclusão de todas as atividades para os 21 discentes que participaram. Logo, foram produzidas cinco questões abertas, nas quais, os participantes tiveram a oportunidade de discorrer a respeito. 
A primeira pergunta esteve relacionada com a percepção dos alunos acerca das estratégias de ensino desenvolvidas nas aulas, a seguir foram descritas as respostas de alguns educandos:

"As aulas foram muito produtivas, muitas dúvidas que eu tinha foram solucionadas, para mim não teve pontos negativos" (Aluno 1)

"É muito importante conhecer os alimentos que comemos e ter consciência das comidas que são consideradas ruins e comemos sem nos importar" (Aluno 2)

"Goste i principalmente quando falamos dos transtornos alimentares, e a diferença ente a bulimia e a anorexia" (Aluno 5)

"As aulas foram ótimas e apesar da alimentação ser presente no nosso dia-a-dia o tema para mim foi novo" (Aluno 6)

"As aulas foram boas e bem legais, aprendemos bastante sobre alimentação, falamos da relação com os laços familiares e de amizade. Seria muito bom se todas as aulas fossem assim" (Aluno 14)

As respostas coletadas demonstraram que todos os alunos foram favoráveis as propostas educativas, referindo-se principalmente a importância do conteúdo abordado.

Sobre a aprendizagem adquirida ao longo das estraté gias de ensino realizadas, os alunos destacaram que:

"Eu aprendi que comidas e lanches processados podem fazer mal a nossa saúde e que o alimento natural traz diversos benefícios para $\mathrm{o}$ organismo" (Aluno 4)

"Nós vimos como as dietas restritivas fazem mal ao organismo e como podemos emagrecer sem exageros" (Aluno 6)

"Eu pude aprender que não se deve exagerar em um determinado alimento e que comer alimentos naturais é muito importante" (Aluno 14)

"Muitos assuntos ficaram claros, principalmente sobre as dietas alimentares" (Aluno 15)

"Eu aprendi que temos que conhecer os alimentos que comemos, não precisa deixar de comer o que gosta é só ter moderação" (Aluno 20)

Com base nas colocações dos estudantes, pode-se perceber que há um padrão de respostas retomadas para a questão de se alimentar de comidas naturais evitando exageros. Acerca das vertentes culturais, sociais, históricas e psicológicas voltadas para a alimentação todos os participantes mostraram-se aderentes a abordagem desse tema sob essas perceptivas, pois segundo eles a alimentação é um conjunto de valores que faz 
parte da história, da cultura, do meio social do indivíduo e de suas condições psicológicas.

A última questão indagou aos discentes sobre os benefícios das estratégias de ensino diferenciadas para contextualizar a educação alimentar, os relatos adquiridos foram os seguintes:

"Estudar o tema dessa forma e uma maneira de cuidarmos da nossa saúde, em muitas escolas existem vários alunos obesos, por exemplo, e poderia ser uma forma de ajudar" (Aluno 2)

"As atividades que fizemos mostrou exemplos reais para que tivéssemos a consciência de que alimentação é um tema muito sério" (Aluno 4)

"Essas atividades não deveriam ser novidade na escola, porque tornam as aulas mais legais e mais interessantes" (Aluno 10)

"É uma forma de ensinar os alunos a terem uma alimentação saudável e equilibrada, além disso, eles poderão repassar para suas famílias e amigos" (Aluno 13)

"Foi muito divertido, trabalhamos todos juntos nos grupos, acho que é mais produtivo do que ficar só ouvindo o professor falar" (Aluno 18)

As colocações dos alunos revelaram que quando se trata de propostas de ensino que os mobilizam, as aulas se tornam mais eficazes para o aprendizado, as ações aplicadas os tornaram mais participativo s e promovem a motivação e interesse perante $o$ assunto trabalhado. Além disso, eles corroboram que a abordagem do tema neste caso, não ficaria restrita ao meio escolar e poderia ser distribuída posteriormente para seu respectivo meio social.

\subsection{Circuito de Ciências e Semana Nacional de Ciência e Tecnologia}

Posteriormente à aplicação da Unidade Didática, o projeto desenvolvido foi inscrito na etapa regional do V circuito de ciências (Figura 8), na cidade de Planaltina, Distrito Federal. Para a apresentação da proposta foram selecionados oito estudantes, daqueles que estavam ativamente interagindo com as atividades desenvolvidas. A escolha desses foi realizada pelos próprios participantes por meio de sufrágio. 


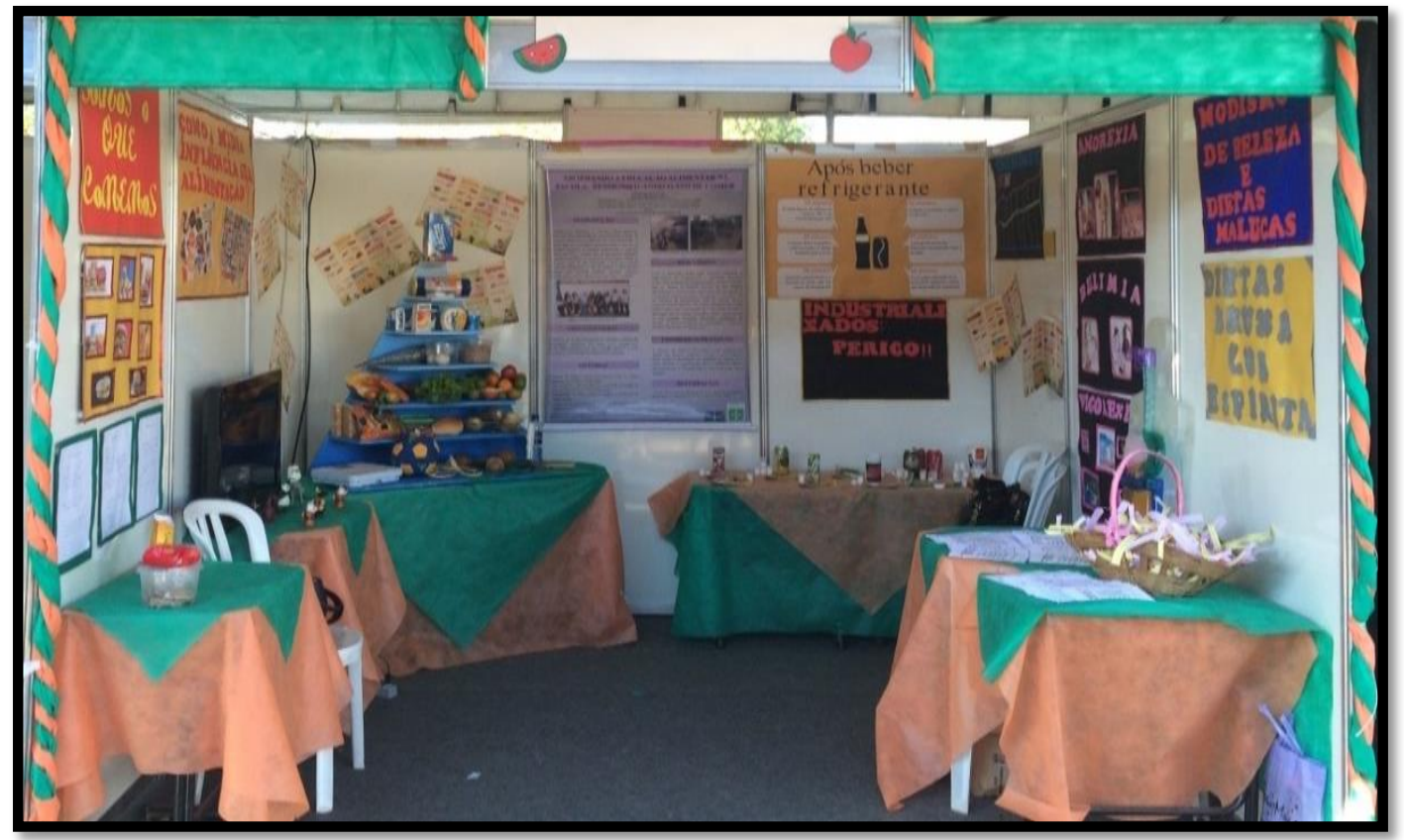

Figura 8. Estande de apresentação no V Circuito de Ciências, etapa regional.

A participação dos educandos foi contributiva para a consolidação dos assuntos abordados na Unidade Didática, os eixos norteadores a serem apresentados no $\mathrm{V}$ circuito de ciências foram indicados pelos alunos, sendo esses: a influência da míd ia na alimentação, o consumo de fast foods, a quantidade de açúcar e gordura nos alimentos industrializados, transtornos alimentares, obesidade, dietas alimentares restritivas e a perspectiva da alimentação saudável e sustentável. Os assuntos foram expostos a partir da confecção de materiais feitos pelos discentes (Figura 9).

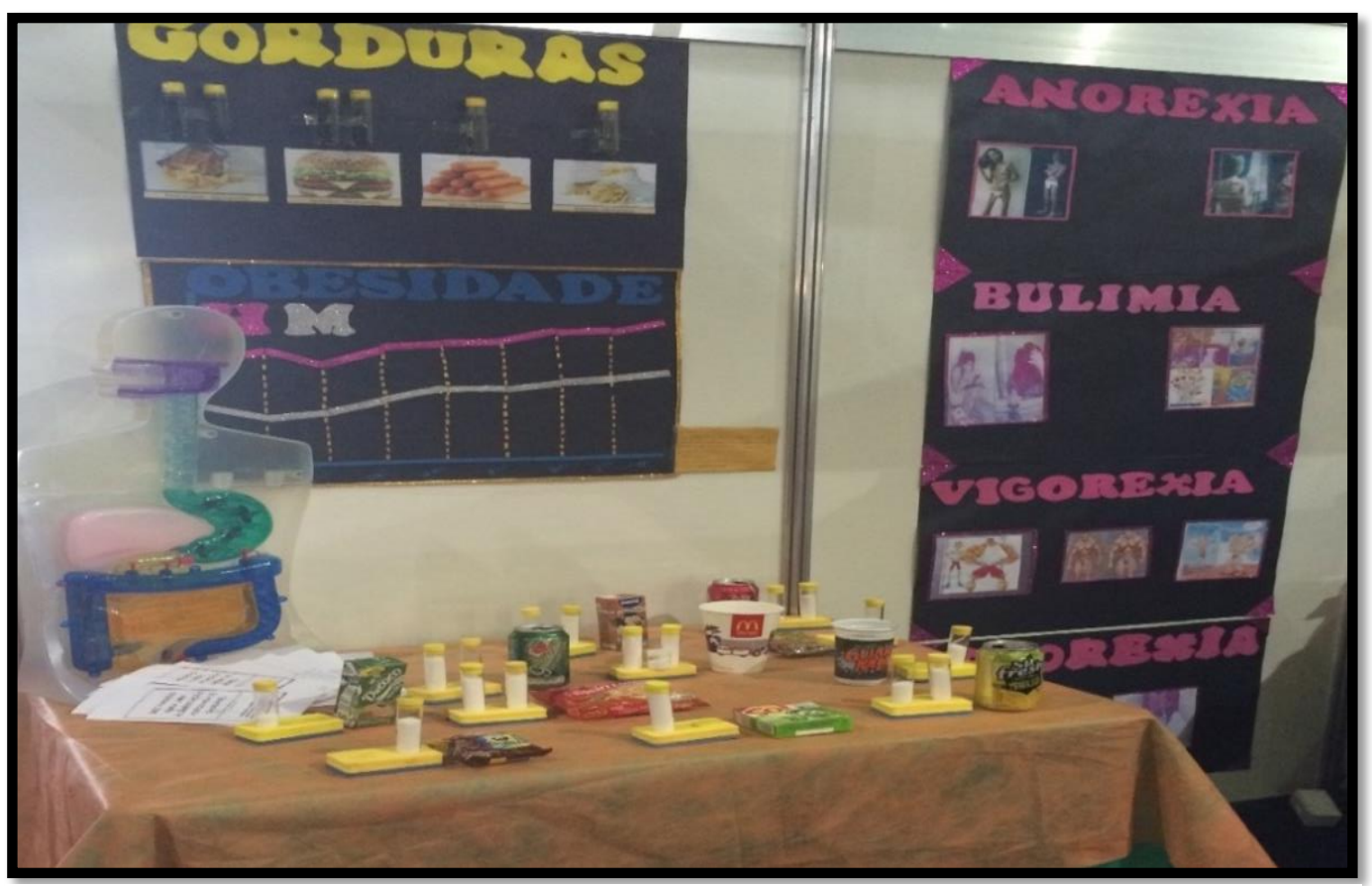

Figura 9. Materiais produzidos pelos alunos para a apresentação. 
Visto que a avaliação feita do projeto se consistiu significativa, obtendo aprovação para etapa seguinte que foi a apresentação na Semana Nacional de Ciência e Tecnologia de Brasilia (Figura 10).

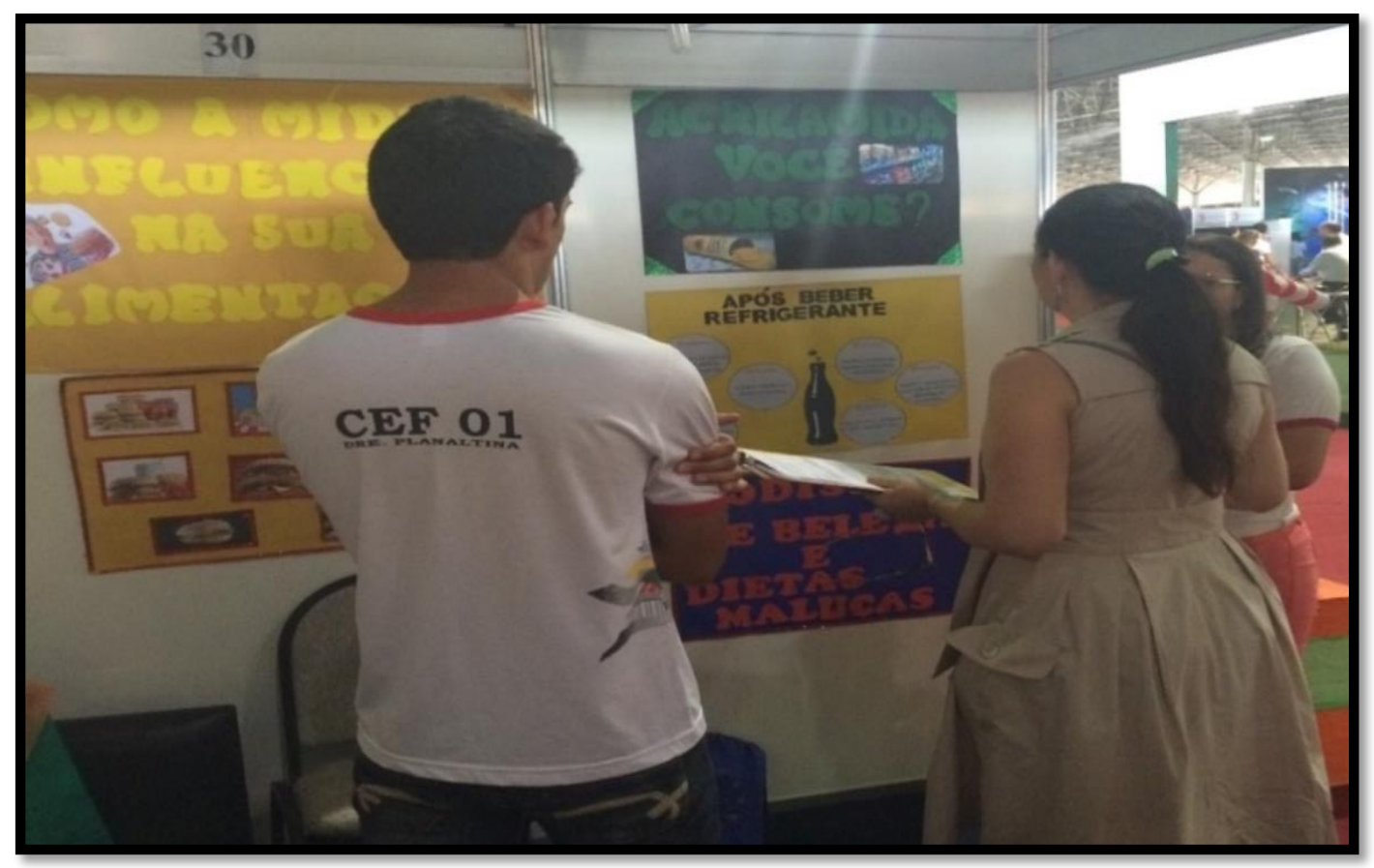

Figura 10. Apresentação na Semana Nacional de Ciência e Tecnologia.

Ao final das exposições os estudantes relataram as experiências vivenciadas ao longo da construção e apresentações do projeto, a seguir destacam-se algumas considerações:

"O projeto foi muito construtivo, trabalhamos em equipe, fomos ativos e nos dedicamos. Em relação à alimentação fiquei mais consciente, agora eu costumo refletir melhor sobre o que estou comendo" (Aluno 1)

"O legal no projeto foi o nosso comprometimento, todos se ajudaram e tivemos a responsabilidade de apresentar os conteúdos que estudamos" (Aluno 3)

"O projeto me ajudou muito na conscientização diante dos alimentos que consumimos. Essa proposta foi uma construção nossa" (Aluno 5)

"É bem melhor estudar desta forma, com atividades dinâmicas, hoje eu tenho uma visão mais crítica da minha alimentação, eu não consigo se quer comer um sanduíche de lanchonetes de fast food" (Aluno 6)

"Tivemos uma parceria com os nossos colegas, foi uma experiência inexplicável a que vivenciamos, construímos juntos o aprendizado e com certeza eu vou levar para vida toda, esse conhecimento" (Aluno 7) 
A perspectiva de construir um projeto a ser apresentado pelos alunos em eventos voltados para a divulgação da ciência tornou essa experiência engrandecedora para estes educandos, nos discursos exibidos nota-se sua motivação e entusiasmo em relação à exposição de suas produções e conhecimentos adquiridos.

A construção do conhecimento de forma ativa por parte dos discentes favorece o interesse por um determinado assunto, problematizar os temas correlacionando com o contexto em que o público está inserido contribui para a formação do pensamento crítico e reflexivo. A conclusão desta proposição educativa, incluindo o V Circuito de Ciências e a Semana Nacional de Ciência e Tecnologia, foi uma forma de obter um feedback do conhecimento apropriado pelos participantes. Percebeu-se que os alunos se preocuparam em divulgar para a sociedade aqueles assuntos que estão presentes no cotidiano dos indivíduos, porém são pouco abordados e as informações são prolixas e em muitos casos encontram-se errôneas. 


\section{DISCUSSÃO}

Este estudo envolveu a produção de uma Unidade Didática referente ao ensino de educação alimentar, a presente proposta fundamentou-se a partir de um questionário inicial aplicado para discentes de séries distintas do Ensino Médio, e posteriormente foi desenvolvida com educandos do $8^{\circ}$ ano do Ensino Fundamental.

Os dados iniciais obtidos com auxílio do questionário relataram que o tema é pouco difundido no ambiente escolar e que os educandos refletem pouco acerca da sua dieta alimentar. Em consonância com Boog (2008, p. 22) "a temática da alimentação é complexa é exige profundidade na análise. Alimentação não é um tema fácil: ele exige uma formação sólida, abrangente e aberta à diversidade", sendo assim, a Unidade Didática desenvolvida buscou englobar o assunto por meio da associação dos aspectos emocionais, sociais, psicológicos e sociais, visando promover a capacidade crítica dos alunos envolvidos. Pollan (2008, p. 16) declara que:

Comida também tem a ver com prazer, comunidade, família e espiritualidade, com a nossa relação com o mundo natural e com a expressão da nossa identidade. Já que os seres humanos fazem refeições juntos, a alimentação tem relação tanto com a cultura quanto com a biologia.

Para Loureiro (2004, p 44) “[...] a capacidade crítica desenvolve-se através de uma reflexão sistemática sobre diferentes situações, consciencializando os seus próprios pensamentos e emoções e confrontando-os com o conhecimento adquirido sobre o assunto", assim, durante toda a ação educativa buscou-se questionar os estudantes da sua realidade alimentar, para que em seguida fossem discutidos os temas inseridos na Unidade Didática.

De acordo com Chassot (2000) o ensino deve ser mais congruente com a história e com realidade e menos catedrático quando se trata de avaliações. Em consenso com essa colocação denota-se que o processo de ensino precisa ser atrativo para o aluno, buscando motivá-lo e torná-lo o principal agente na construção do seu conhecimento. A ação educativa, tendo como eixo norteador atividades de ensino problematizadoras favoreceu essa concepção e permitiu que os estudantes tivessem momentos contínuos de reflexão mediante sua respectiva alimentação. 
Outro dado relevante, adquirido como subsídio do questionário inicial, está correlacionado com a quantidade de dietas alimentares restritivas do conhecimento dos participantes. Ademais, as fontes de pesquisa destas informações baseiam-se principalmente em redes sociais ou sites que apresentam percepções sobre o tema. Deram (2014, p. 60) relata que:

As dicas que você recebe da mídia, do médico, ou da nutricionista, da academia, da vizinha se confundem e, às vezes, são contraditórias. A informação que as revistas passam é na maioria das vezes, sensacionalista, simplificada ou explicada por uma pseudociência, ou seja, a mensagem não é tão precisa e pode incentivar comportamentos não tão saudáveis. $\mathrm{O}$ tempo todo você recebe dicas que dizem que precisa controlar a sua alimentação, decretar guerra ao açúcar, ao glúten, à lactose, e tudo isso num ambiente que vende produtos muito gostosos, mas que você não deveria comer porque suspostamente engordam.

Ao longo das atividades desenvolvidas os educandos tiveram a oportunidade de expressar as suas experiências em relação à alimentação. Os dados descritos demonstram nitidamente que a participação dos alunos foi efetiva, e que o tema é bastante presente no cotidiano deles, no entanto há pouco discernimento do assunto e as informações que possuem são ainda difusas. De acordo com Luca e Santos (2010, p.18) “o mundo é entendido pelos conceitos que construímos e pelas palavras que os traduzem. Quando estas palavras passam a fazer parte dos discursos, o significado, então é elaborado".

As atividades de ensino em educação alimentar propendendo atrelar fatores químicos, biológicos, sociais, culturais e psicológicos partem do principio que o aluno precisa compreender esses aspectos como algo que está imerso em sua vida para que assim a motivação para aprender seja significativa e relevante para sua formação quanto cidadão reflexivo. Neste caso, a ação da escola e do professor deve superar a fragmentação entre o ensino e a realidade do estudante, visando oferecer perspectivas colaborativas para construção do aprendizado.

Pode-se observar por meio da aplicação da Unidade Didática que a fundamentação da educação alimentar na escola com estratégias de ensino diferenciadas, fortalece as condições de promoção da saúde e contribui para melhorias no desenvolvimento humano. Além disso, o ambiente escolar permite o desenvolvimento de habilidades, valores, conduta de zelo com saúde (YOKOTA et al, 2010). 
Programar atividades de educação alimentar na escola com crianças e adolescentes fomenta a construção de conhecimentos retornados para a incorporação de hábitos mais saudáveis que possam ser ampliados para as famílias e para a comunidade escolar (MARTINS; WALDER; RUBIATTI, 2010).

As ações educativas foram desenvolvidas com o sentido de gerar a autonomia nos participantes, baseando-se na interdisciplinaridade e considerando as vivências dos indivíduos de acordo com a sua cultura e regionalidade para que assim fosse valorizada a diversidade de alimentos existentes (SANTOS, 2012). Ainda sobre essa colocação, Boog (2008, p. 59) assegura que "educar em alimentação implica resgatar a dignidade, esperança, autoconfiança e energia para a luta cotidiana daqueles que se encontram empobrecidos e excluídos".

Pode-se averiguar em relação ao questionário final que os alunos tiveram compreensão do desígnio das ações pedagógicas e realçaram que as propostas de ensino trabalhadas colaboram para despertar o interesse no assunto, além de tornar o contexto de sala de aula mais atrativo e dinâmico para a aprendizagem. Luca e Santos (2010, p.19) indicam que "estarmos alfabetizados cientificamente para a escolha dos nossos alimentos ultrapassa características evolutivas, fazendo-nos mais atuantes e mais compromissados com o uso da ciência".

No que concerne à divulgação dos conhecimentos adquiridos pelos educandos, no V Circuito de Ciências e na Semana Nacional de Ciência e Tecnologia, notou-se que houve uma preocupação destes em expor com clareza as informações apropriadas, foi perceptível a interação e comprometimento do grupo. Essa concepção infere sobre a relevância de mobilizar o discente em relação a sua responsabilidade no seu proce sso de ensino, de acordo com Bisinoto (2012, p.13):

É importante, e necessário, propor aos alunos atividades diferentes daquelas que vêm sendo utilizadas, de modo a possibilitar-lhes novas experiências de aprendizagem; experiências ativas, diversificadas, integradoras e potencialmente capazes de desenvolver sujeitos competentes para se inserirem numa sociedade dinâmica, complexa e contraditória como a nossa.

Considerando ainda o aspecto mencionado acima Gazzinelli et al (2005, p. 201 202) afirma que "as práticas educativas pautadas nesta perspectiva conteudista, normativa e cientificista demoraram a demonstrar que aquisição de saber instituído não resulta, necessariamente, em mudança de comportamento". 
Retomando o questionário final, as respostas dadas pelos discentes apontaram que as estratégias de ensino beneficiaram o aprendizado e que a intervenção do professor deve estar associada continuamente à otimização de atividades que apresentem um pluralismo de concepções intrínsecas ao assunto a ser desenvolvido em contexto de sala de aula, não se limitando apenas a exposição teórica. Para Zancul e Gomes (2011, p. 51), “o papel da escola vem se tornando cada vez mais importante na formação de hábitos saudáveis. Nesse ambiente, deve haver espaço para educadores e alunos discutirem questões sobre saúde”.

Entende-se, em conformidade com a obtenção dos dados, que a educação alimentar deve envolver o processamento cognitivo e a estimulação do estudante, para tanto atividades cooperativas, na qual os discentes baseiam-se no trabalho interativo com o objeto de estudo precisam ser implantadas com frequência no ambiente escolar. 


\section{CONSIDERAÇÕES FINAIS}

A efetivação deste estudo possibilitou a introdução de subsídios metodológicos diferenciados na abordagem de educação alimentar. Notou-se a principio que é existente a ausência de estratégias que visem fomentar o assunto de maneira critica, na qual os educandos possam refletir mediante a sua alimentação. Deste modo, o presente trabalho buscou desfavorecer o condicionamento gerado pelas propagandas publicitárias e corriqueiramente pela sociedade.

$\mathrm{O}$ uso das atividades propostas no material didático proporcionou a interação do conhecimento alusivo à alimentação entre os discentes, permitindo a reflexão sobre padrões conferidos diariamente pelo meio em que estão inseridos. Tendo em vista, os dados obtidos, conclui-se que a educação alimentar deve estar continuamente presente no ambiente escolar. Além disso, o trabalho pedagógico nesta área não está unicamente associado à disciplina de ciências, mas igualmente nos demais campos do conhecimento.

Com os resultados obtidos pode-se compreender que quando se trata de educação alimentar, o professor deve considerar primordialmente a singularidade do individuo, buscando intervir de modo que a sua participação seja ativa no processo de cons trução do conhecimento. Apesar das limitações nas escolas públicas, em evidência a falta de materiais e estrutura física, o professor pode adotar métodos que se constituam eficazes e simples para o desenvolvimento no ambiente de sala da aula. As estratégias inseridas na Unidade Didática cumprem sua função em relação a esses aspectos e podem ser pontos iniciais para a discussão da alimentação na escola.

$\mathrm{O}$ engajamento dos discentes em atividades probematizadoras torna o ensino consistente e crítico, proporcionando a contextualização da educação alimentar e a formação de cidadãos conscientes que buscam por condições adequadas para sua saúde. Salienta-se que as proposições associadas a esse estudo envolvem a troca de experiências e aprendizagem e cabe ao educador orientar o seu público para que o ensino nesta área seja significativo e favoreça a autonomia dos educandos.

Este trabalho contribuiu imensamente para minha formação como professora e pesquisadora, como mencionado anteriormente a educação alimentar ainda é um campo pouco difundido e ainda delimitado no âmbito escolar, deste modo espera-se que este 
estudo sirva como eixo norteador para o tratamento do tema em sala de aula, e que o professor compreenda a importância de divulgar os resultados obtidos com seus alunos a fim de favorecer a constância do assunto no ambiente escolar e a expansão da temática no meio acadêmico. 


\section{REFERÊNCIAS BIBLIOGÁFICAS}

ALENCAR, E. M. L. S. de. O Contexto Educacional e sua Influência na Criatividade. Revista Linhas Crítica, v. 8, n. 15, p. 165-178. Brasilia: jul/dez 2002.

ANDRADE, A.; BOSI, M. L. M. Mídia e subjetividade: impacto no comportamento alimentar feminino. Revista de Nutrição, n. 1, v. 16, p. 117-125, jan/mar. 2003.

BARBOSA, N. V. S.; MACHADO, N. M. V.; SOARES, M. C. V.; PINTO, A. R. R. Alimentação na escola e autonomia: desafios e possibilidades. Ciências \& Saúde Coletiva, v. 18, n. 4, p. 937-945, 2012.

BARROS, C.; PAULINO, W. Ciências e o corpo humano. $4^{a}$ ed. São Paulo: ática, 2011.

BISINOTO, C. Educação, escola e desenvolvimento humano: Articulações e implicações para o ensino de ciências. In: GUIMARÃES, E. CAIXETA, J. (Orgs.), Trilhas e Encontros: Mediações e Reflexões sobre o Ensino de Ciências. P. 11-31. Curitiba: CRV, 2012.

BOOG, M. C. F. Educação nutricional: passado, presente, futuro. Revista Nutrição, n. 1, v. 10, p. 5-19, jan./jun. 1997.

O professor e a alimentação escolar: ensinando a amar a terra e o que a terra produz. Campinas: Komedi, 2008.

BRASIL. Parâmetros curriculares nacionais: terceiro e quarto ciclos: apresentação dos temas transversais/Secretária de educação fundamental. Brasília: 1998.

BRASIL. Lei de Diretrizes e Bases da Educação Nacional. Lei Federal no 9.394, de 20 de dezembro de 1996. 9 ed. Brasília: Câmara dos Deputados, Edições Câmara, 2014a.

BRASIL. Ministério da Saúde. Secretaria de Atenção à Saúde. Departamento de Atenção Básica. Guia alimentar para a população brasileira. $2^{\mathrm{a}}$ ed. Brasília: Ministério da Saúde, 2014b. 
BULGRAEN, V. C. O Papel do Professor e sua Mediação nos Processos de Elaboração do Conhecimento. Revista Conteúdo, v. 1, n. 4, Capivari, ago./dez. 2010.

BULMER, M. Sociological research methods. London: Macmillan, 1977.

CANDEIAS, N. M. F. Conceitos de educação e de promoção em saúde: mudanças individuais e mudanças organizacionais. Rev. Saúde Pública, n. 2, v. 31, p. 209-213. São Paulo: 1997.

CANEIRO, H. Comida e sociedade: Uma história da alimentação. 3 ed. Rio de Janeiro: Elsevier, 2003.

CHASSOT, A. Alfabetização científica: questões e desafios para a educação. Ijuí: UNIJUİ, 2000.

CONTRERAS, J.; GARCIA, M. Alimentação, sociedade e cultura. Rio de janeiro: Editora Fiocruz, 2011.

COSTA, J. O Papel da Escola na Sociedade Actual: Implicações no Ensino das Ciências. Revista Millenium, vol. 15, p. 56-62, 1999.

COSTA, M. F. Consumo alimentar: discurso científico em anúncios publicitários. Revista Contemporânea, n. 13, v. 2, p. 131-140, 2009.

DELIZOICOV, D.; ANGOTTI, J. A.; PERNAMBUCO, M. M. Ensino de Ciências: Fundamentos e métodos. $2^{\text {a }}$ ed. São Paulo: Cortez, 2007.

DERAM, S. O peso das dietas: emagreça de forma sustentável dizendo não as dietas!. $1^{\text {a }}$ ed. São Paulo: Sensus, 2014.

DOMENE, S. M. A. A escola como ambiente de promoção da saúde e educação nutricional. Psicologia USP, n.4, v. 19, p. 505-517, out./dez. 2008.

DRIVER, R.; ASOLO, H.; LEACH, J.; MORTIMER, E.; SCOTT, P. Construindo conhecimento científico na sala de aula. Química Nova na Escola, n. 9, p. 31-40 maio, 1999. 
FERREIRA, A. B. de H. Minidicionário século XXI escolar: O minidicionário da língua portuguesa. 4a ed. rev. Ampliada. Rio de Janeiro: Nova Fronteira, 2001.

FISCHLER, C. A "McDonaldização" dos costumes. In: FLANDRIN, J. L.; MONTANARI, M. História da alimentação. P. 841-862. São Paulo: Estação Liberdade, 1998.

FONSECA, C. V.; LONGUERCIO, R. de Q. Conexões entre química e nutrição no ensino médio: Reflexões pelo enfoque das representações sociais dos estudantes. Química Nova na Escola, n. 2, v. 35, p. 132-140, maio 2013.

FREIRE, P. Pedagogia do Oprimido. 48 ed. Rio de Janeiro: Paz e terra, 2005.

Educação e mudança. 34 ed. São Paulo: Paz e terra, 2011b.

GARCIA, R. W. D. Dieta Mediterrânea: Inconsistência ao se Preconizar Modelos de Dietas. Cadernos de Debate, v. 8, p. 28-36, 2001.

GAVIDIA, V. El profesorado ante La educación y promoción de la salud em la escuela. Didáctica de las Ciencias Experimentales y Sociales, n. 23, p. 171-180, 2009.

GAZZINELLI, M. F.; GAZZINELLI, A.; REIS, D. C.; PENNA, C. M. M. Educação em saúde: conhecimentos, representações sociais e experiências da doença. Caderno de Saúde Pública, v. 21, n. 1, p. 200-206, 2005.

GIL, A. C. Métodos e técnicas de pesquisa social. $6^{\text {a }}$ ed. São Paulo: Atlas, 2008.

GÓES, J. A. W. Hábitos alimentares: Globalização ou Diversidade? In: FREITAS, M. do C. S.de; FONTES, G. A. V.; OLIVEIRA, N. de. Escritas e narrativas sobre alimentação e cultura. P. 375-404. Salvador: EDUFBA, 2008.

GOMES, K. dos. S.; FONSECA, A. B. Programa nacional de alimentação escolar e suas possibilidades para a educação alimentar e nutricional: uma revisão da literatura. Atas do IX Encontro Nacional de Pesquisa em Educação em Ciências - IX ENPEC; 10 a 14 de novembro; Águas de Lindóia. São Paulo: 2013.

JOMORI, M. M.; PROENÇA, R. P. da C.; CALVO, M. C. M. Determinantes de escolha alimentar. Rev. Nutr., v. 21, n. 1, p. 63-73, 2008. 
LAVILlE C.; DIONNE, J. A construção do saber: manual de metodologia da pesquisa ciências humanas. Porto Alegre: Artmed; Belo Horizonte: Editora UFMG, 1999.

LIBÂNEO, J. C. Didática. 1 ed. São Paulo: Cortez, 1996.

LIMA, K. A.; COSTA, F. N. do A. Educação em saúde e pesquisa qualitativa: Relações possíveis. Alimentação e Nutrição Araraquara, n. 1, v. 16, p. 33-338, jan./mar. 2005.

LOPES, S.; ROSSO, S. Bio: volume 1. 1ª ed. São Paulo: Saraiva, 2010.

LOUREIRO, I. A importância da educação alimentar: O papel das escolas promotoras de saúde. Educação alimentar, v. 22, n. 2, p. 43-55, 2004.

LUCA, A. G.; SANTOS, S. A. dos. Dialogando ciência entre sabores, odores e aromas: contextualizando alimentos química e biologicamente. São Paulo: Livraria da Física, 2010.

LÜDKE, M.; ANDRÉ, M.E.D.A. Pesquisa em Educação: Abordagens Qualitativas. São Paulo: EPU, 1986.

MALTA, D. C.; ISER, B. P. M.; CLARO, R. M.; MOURA, L. de.; BERNAL, R. T. I.; NASCIMENTO, A. de F.; JÚNIOR DA SILVA, B. J.; MONTEIRO, C. A. Prevalência de fatores de risco e proteção para doenças crônicas não transmissíveis em adultos: estudo transversal, Brasil, 2011. Epidemiol. Serv. Saúde, n. 2, v. 22, p. 423-434. Brasilia: jul./set. 2013.

MANÇO, A. de M.; COSTA, F. N. de A. Educação nutricional: Caminhos possíveis. Alimentação e Nutrição Araraquara, n.2, v. 15, p. 145-153, 2004.

MARCONDES, R. S. Educação em saúde na escola. Revista de Saúde Pública, n. 1, v. 6, p. 89-96, 1972.

MARTINS, J. A pesquisa qualitativa. In: FAZENDA, I. (org.). Metodologia da pesquisa educacional. P. 47-59, 6 ed. São Paulo: Cortez, 2000. 
MARTINS, D.; WALDER, B. S. M.; RUBIATTI, A. de M. M. Educação nutricional: atuando na formação de hábitos alimentares saudáveis de crianças em idade escolar. Rev. Simbio-Logias, v. 3, n.4, junho/2010.

MOURA, N. C. de. Influência da mídia no comportamento alimentar de crianças e adolescentes. Segurança Alimentar e Nutricional, n. 1, v. 17, p. 113-122, 2010.

MOHR, A.; SCHALL, V. Rumos da educação em saúde no Brasil e sua relação com a educação ambiental. Cadernos de Saúde Pública, v. 8, n. 2, p. 199-203. Rio de Janeiro: abr./jun., 1992.

PACHECO, C. Q; OLIVEIRA, M. A. M. de.; STRACIERI, A. P. M. Análise nutricional de dietas publicadas em revistas não científicas destinadas ao público feminino. Revista Digital de Nutrição, n. 4, v. 3, p. 346-361. Ipatinga: fev./jul. 2009.

POLLAN, M. Em defesa da comida: um manifes to. Rio de Janeiro: Intrínseca, 2008.

RADAELLI, P.; RECINE, E. Comportamento alimentar e promoção da saúde. Universitas Ciências da Saúde, n. 2, v. 02, p. 267-280, 2004.

RODRIGUES, L. P. F.; RONCADA, M. J. Educação nutricional no Brasil: evolução e descrição de proposta metodológica para escolas. Com. Ciência e Saúde, n. 4, v. 19, p. 315-322, 2008.

RODRIGUES, L. P. F. Guia de promoção da alimentação saudável e sustentável para escolas. Brasîlia: Universidade de Brasîlia, Decanato de Extensão, 2011.

ROCHA, M. L da. Pesquisa-Intervenção e a produção de novas análise. Psicologia ciência e profissão, n. 4, v. 23, 64-73, 2003.

ROCHA, M. L. da. Psicologia e as práticas institucionais: a pesquisa-intervenção em movimento. Psico, v. 37 n. 2, p. 169-174, maio/ago 2006.

SANTOS, L. A. da S. Educação alimentar e nutricional no contexto da promoção de práticas alimentares saudáveis. Revista Nutrição, n. 5, v. 18, 681-692, set./out. 2005. 
Da dieta à reeducação alimentar: algumas notas sobre o comer contemporânea a partir dos programas de emagrecimento na internet. Revista de Saúde Coletiva, n. 20, v. 2, p. 459-474. Rio de Janeiro: 2010.

. O fazer educação alimentar e nutricional: algumas contribuições

para reflexão. Ciência e Saúde Coletiva, n. 17, v. 2, p. 453-462, 2012.

SANTOS, W. L. P.; MÓL, G. S. (coordenadores); Química e Sociedade. $1^{\text {a }}$ edição, São Paulo: editora nova geração, 2011.

SCHMITZ, B. de A. S.; R. E.; CARDOSO, G. T.; SILVA, J. R. M. da; AMORIM, N. F. de A.; BERNARDON, R.; RODRIGUES, M. L. C. F. A escola promovendo hábitos alimentares saudáveis: uma proposta metodológica de capacitação para educadores e donos de cantina escolar. Cad. Saúde Pública, v. 24, p. 312-322, 2008.

SAVIOLI, G. Alimente bem suas emoções. 4ª edição. São Paulo: editora Loyola, 2014.

SERRA, G. M. A.; SANTOS, E. M. Saúde e míd ia na construção da obesidade e do corpo perfeito. Ciência \& Saúde Coletiva, n. 3, v. 8, p. 691-701, 2003.

STRÜMER, J. Comida: um santo remédio. $3^{\mathrm{a}}$ edição. Petrópolis, RJ: editora Vozes, 2002.

TUNES, E.; TACCA, M. C. V. R.; JÚNIOR BARTHOLO, R. dos S. O professor e o ato de ensinar. Cadernos de Pesquisa, n. 126, v. 35, p. 689-698, set./dez. 2005.

VASCONCELOS, J. L.; GEWANDSZNAJDER, F. Programas de saúde. $11^{\text {a }}$ edição, São Paulo: editora Ática, 1986.

YOKOTA, R. T. de C.; VASCONCELOS, T. F. de; PINHEIRO, A. R. de O.; SCHMITZ, B. de A. S.; COITINHO, D. C.; RODRIGUES, M. de L. C. F. Projeto "a escola promovendo hábitos alimentares saudáveis": Comparação de duas estratégias de educação nutricional no Distrito Federal, Brasil. Revista Nutrição, n. 23, v. 1, p. 37-47, jan./fev. 2010.

ZANCUL, M. de S.; DUTRA DE OLIVEIRA, J. E. Considerações sobre ações atuais de educação alimentar e nutricional para adolescentes. Alimentação e Nutrição Araraqua ra, n. 2, v. 18, jan./mar. 2007. 
ZANCUL, M. de S.; GOMES, P. H. M. A formação de licenciandos em ciências biológicas para trabalhar temas de educação e saúde na escola. REMPEC - Ensino, saúde e ambiente, n. 1, v. 4, p. 49-61, abril 2011. 
APÊNDICE A - Questionário Inicial para os Alunos

UNIVERSIDADE DE BRASÍLIA

Programa de Pós-Graduação em Ensino de Ciências

Mestrado Profissionalizante em Ensino de Ciências

"Educação Alimentar: um estudo a respeito da percepção de adolescentes acerca de dietas alimentares"

Pesquisadora: Lays Batista Martins Leite

\section{IDENTIFICAÇÃO}

Nome:

Escola:

Série:_ Idade:

\section{PERCEPÇÃO}

1. O que você entende por Dieta?

2. Você conhece algum tipo de dieta?

( ) Sim, qual?

( ) Não

( ) Não sabe

3. Você já fez alguma dieta? 
( ) Sim, como?

( ) Não

( ) Não sabe

4. Onde você costuma buscar informações a respeito deste tema?

5. Você se lembra de ter estudado a respeito de Dietas na escola?

( ) Sim, em qual disciplina ?

( ) Não

( ) Não sabe

6. Você acredita que as Dietas podem trazer benefícios para sua saúde?

( ) Sim, como?

( ) Não

( ) Não sabe 


\section{APÊNDICE B - Questionário Final para os Alunos}

UNIVERSIDADE DE BRASÍLIA

Programa de Pós-Graduação em Ensino de Ciências

Mestrado Profissionalizante em Ensino de Ciências

\section{QUESTIONÁRIO FINAL PARA OS ALUNOS}

1. O que você achou das atividades desenvolvidas nas aulas?

2. Com o desenvolvimento das atividades você conseguiu obter algum aprendizado importante para sua formação? Comente a respeito.

3. Você acha que a educação alimentar deve ser trabalhada na escola a partir das vertentes histórica, cultural, social e psicológica? Por quê?

4. Você acredita que as estratégias de ensino utilizadas são atrativas para trabalhar o tema na escola? Justifique. 


\section{APÊNDICE C - Carta de Aceite Institucional}

\section{AUTORIZAÇÃo PARA APLICAÇÃO DE PROJETO DE PESQUISA ACADÊMICA}

Prezada Diretora do Centro de Ensino Fundamental 01 de Planaltina - DF

Venho solicitar a sua autorização para a aplicação do projeto "Educação alimentar no contexto escolar: o uso de estratégias diferenciadas de ensino" de responsabilidade de Lays Batista Martins Leite, aluna do Programa de Pós-graduação em Ensino de Ciências da Universidade de Brasília, realizada sob orientação dos Professores Dr. ${ }^{a}$ Mariana de Senzi Zancul e Dr. Gerson de Souza Mól.

O estudo envolve a aplicação de uma Unidade Didática cuja temática é a educação alimentar na escola, desenvolvendo subsídios que auxiliem a intervenção pedagógica de forma interdisciplinar, englobando principalmente aspectos químicos, biológicos, sociais, culturais e emocionais que se relacionam à temática.

A proposta será aplicada no horário inverso de aula para 21 alunos do $8^{\circ}$ ano do Ensino Fundamental, ou seja, no período vespertino, no laboratório de ciências e/ou sala de vídeo desta escola. As datas prováveis são: 10/09, 14/09, 21/09, 24/09 e 28/09, com o tempo estimado de duração de 1 h e 30 minutos.

Salientamos ainda que não haverá risco a integridade física, moral ou mental dos alunos participantes, nem risco para a instituição. Os responsáveis dos estudantes também serão informados acerca desta proposição.

Brasilia, de setembro de 2015.

Lays Batista Martins Leite

Dr ${ }^{\circ}$ Gerson de Souza Mól.

De acordo do Centro de Ensino

Assinatura do responsável pela instituição. 


\section{APÊNDICE D - Termo de Consentimento Livre e Esclarecido}

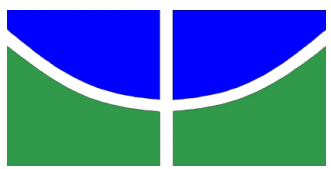

UNIVERSIDADE DE BRASÍLIA

Programa de Pós-Graduação em Ensino de Ciências

Mestrado Profissionalizante em Ensino de Ciências

\section{Termo de Consentimento Livre e Esclarecido}

Você está sendo convidado (a) para participar da pesquisa "Educação alimentar no ensino de ciências: o caso das dietas alimentares" de responsabilidade de Lays Batista Martins Leite, aluna do Programa de Pós-Graduação em Ensino de Ciências da Universidade de Brasília, sob orientação dos Professores Dr. ${ }^{a}$ Mariana de Senzi Zancul e Dr. Gerson de Souza Mól.

A pesquisa tem como objetivo conhecer a visão de estudantes do Ensino Médio, pertencentes a essa instituição, sobre dietas alimentares. Para isso, será aplicado um questionário com perguntas abertas e objetivas individualmente.

Espera-se com essa pesquisa conhecer as percepções dos discentes acerca do tema, para que posteriormente se desenvolva uma Unidade Didática sobre educação alimentar para a intervenção em sala de aula. A participação na pesquisa não oferece nenhum tipo de risco ao participante, sendo-lhe garantido o sigilo quanto à sua identidade.

Salienta-se que a sua participação é voluntária e livre de qualquer remuneração financeira. Você é livre para recusar-se a participar, retirar seu consentimento ou interromper sua participação a qualquer momento. A recusa em participar não irá acarretar qualquer penalidade.

Este documento foi elaborado em duas vias, uma ficará com a pesquisadora responsável pelo estudo e a outra com você.

Considerando que todas as dúvidas foram esclarecidas, a proposta e os procedimentos envolvidos no estudo foram apresentados, solicito o seu consentimento, expressando seu interesse e autorização. 


\section{APÊNDICE E-Situações problemas sobre dietas alimentares (atividade 5)}

\section{Situação 1}

Layla é uma adolescente de quinze anos, todos os dias ela sofre bullying na escola devido ao seu excesso de peso. Ela é uma garota com autoestima baixa e se sente bastante triste com os comentários realizados pelos colegas. Com intuito de emagrecer rapidamente, Layla resolveu aderir a uma dieta alimentar, na qual ela só irá ingerir sopa e água por 40 dias. Vocês acham que esse tipo de dieta traz benefícios para a saúde desta adolescente? Vocês já fizeram alguma dieta restritiva como a que Layla pretende realizar? Quais as consequências esse tipo de dieta pode gerar para a saúde da adolescente? Vocês acham que o excesso de peso é uma doença? Qual a medida correta Layla pode recorrer para emagrecer?

\section{Situação 2}

Júnior tem dezessete anos e há um ano exercita musculação diariamente. Desde então, ele tem uma dieta bastante rígida, consumindo apenas proteínas, a adoção desta dieta surgiu com o objetivo de adquirir massa muscular. Vocês acham a medida assentida por Júnior é adequada para sua saúde? Vocês conhecem pessoas que possuem esse tipo de dieta? Quais as consequências desse tipo de dieta para a saúde de Júnior? Existem outros meios para se adquirir massa muscular?

\section{Situacão 3}

Evelyn desde a infância sonha em ser modelo, no entanto, algumas restrições em sua alimentação devem ser adotas para manter o seu peso. Atualmente Evelyn faz poucas refeições diárias e muitas vezes se priva totalmente dos alimentos. Vocês acham a postura de Evelyn saudável em relação a sua alimentação? Quais os danos à dieta aderida por ela pode causar a sua saúde? Quais outros métodos considerados saudáveis ela pode adotar para manter o peso? 


\section{APÊNDICE F - Atividade complementar (atividade 8)}

\section{Dez Passo para uma Alimentação Adequada e Saudável}

Complete as lacunas com as dez indicações feitas pelo Guia Alimentar da População Brasileira (2014) para uma alimentação adequada e saudável:

1. Fazer de alimentos

ou minimamente processados a base da alimentação.

2. Utilizar óleos, gorduras, sal e açúcar em ao temperar e cozinhar alimentos e criar preparações culinárias.

3. o consumo de alimentos processados.

4. Evitar o consumo de

5. Comer com e atenção em ambientes apropriados e, sempre que possível, com

6. Fazer compra em locais que ofertem variedades de alimentos ou minimamente processados.

7. habilidades culinárias.

8. Planejar o uso do para dar à

o espaço que ela merece.

9. Dar preferência, quando fora de casa, a locais que servem feitas na hora.

10. Ser quanto a informações, orientações e mensagens sobre alimentação veiculadas em 
APÊNDICE G - Atividade complementar (atividade 9)

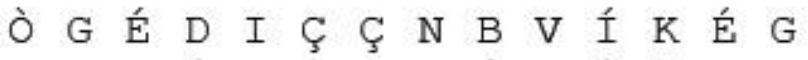

O T E I $\mathrm{M}$ Ç A U Ô Y Ô U̇ $G$ W

C E V V

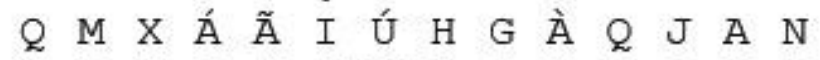

$\begin{array}{lllllllllllllll}A & R & F & R & M & J & N & U & C & C & U & Q & H & P\end{array}$

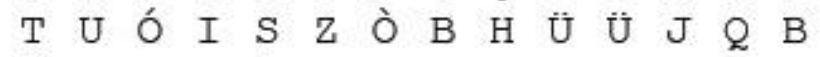

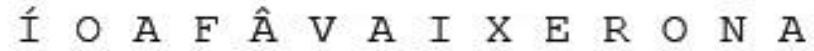

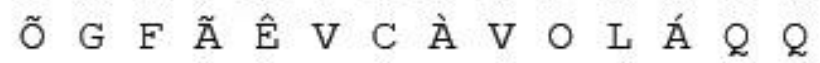

O E A Í Â $P$ É $F$ Á $P$ Ú $V$ Y

Ü M S Ú Á ó $\tilde{A}$ É $R \quad K \quad C ̧ \quad \widehat{A}$ Á $\hat{E}$

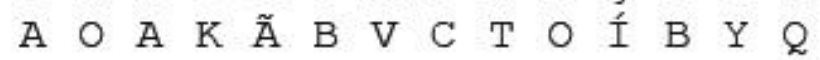

$\begin{array}{llllllllllllll} & R & T & I & L & L & I & W & R & E & D & A & R\end{array}$

$\begin{array}{lllllllllllllll}\tilde{O} & D & T & \hat{E} & \tilde{A} & H & \tilde{A} & H & Q & O & N & I & X & U\end{array}$

Y $N$ E $\hat{E}$ L $U$ O O $T$ T $S$ M R Ô

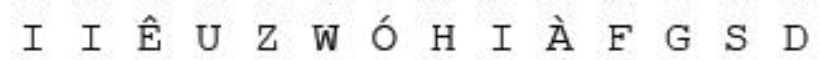

T S Õ $\hat{A}$ O

J $\mathrm{P}$ I $\mathrm{K}$ Á $\mathrm{C}$ Ú $\mathrm{C}$ Ú

$\begin{array}{llllllllllllll}N & \grave{A} & N & \tilde{A} & E & R & C & I & \hat{A} & U & A & H & R & I\end{array}$

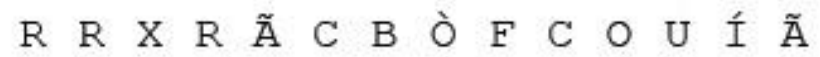

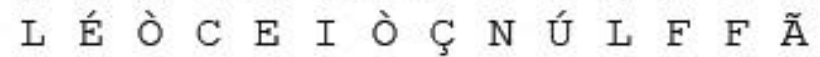

Ü Í Â X Ô Ô Ô Z C C Ú Ò $M$ Í $E$

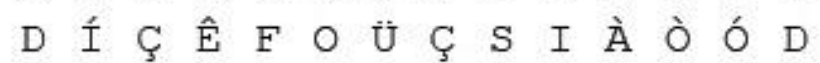

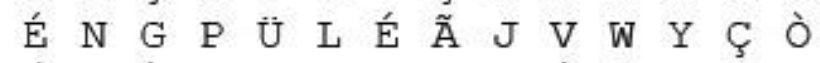

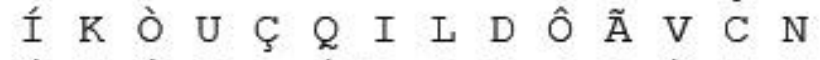

Á $J$ É $\quad$ X
ORTOREXIA

ANOREXIA

PRADERWILLI

SINDROMEGOURMET

BULIMIA 
APÊNDICE H - Atividade complementar (atividade 10)

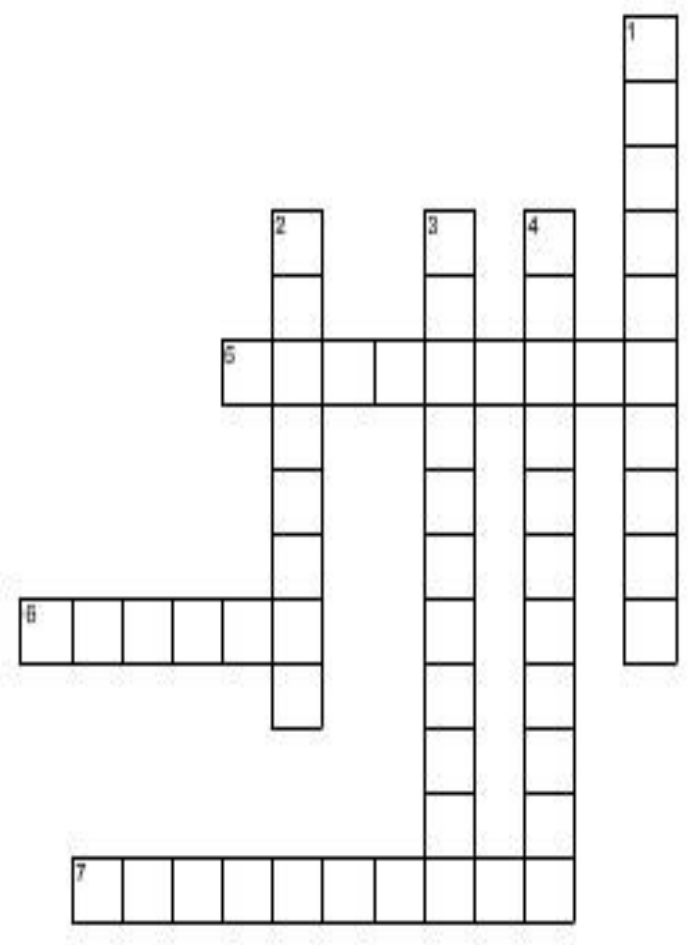

1. Fixação por uma alimentação saudável.

2. Formado a partir de diversos fatores: culturais, psicológicos e sociais.

3. Traço individual de cada pessoa.

4. Apresentam os primeiros sintomas geralmente na infância e adolescência.

5. Doença causada pelo acúmulo de gordura.

6. Medidas adquiridas com o intuito de emagrecimento.

7. Opções práticas e cômodas para a maioria das pessoas. 


\section{ANEXO A - Texto de divulgação científica (atividade 3)}

\section{Porque gostamos tanto de comida?}

\section{Muito além da resposta "porque comer é bom": somos a única espécie que cultiva e cozinha alimentos}

Ah, a comida! Todo mundo precisa de comida para sobreviver, mas por que continuamos procurando novas maneiras de preparar pratos cada vez mais diferentes e saborosos?

Os hábitos alimentares dos seres humanos têm causado grandes mudanças evolutivas no corpo. O biólogo evolucionista da Universidade de New South Wales, Darren Curnoe, explica que cozinhar é uma atividade totalmente enraizada em nossa existência. "Somos a única espécie que cultiva e cozinha os alimentos".

Cozinhamos - e não é de hoje. Bem antes da agricultura, que data de 10 mil anos atrás, já existiam registros de cozimento de alimentos. Cozinhar deu uma vantagem enorme aos nossos ancestrais em relação às outras espécies afinal os alimentos ficavam livres de bactérias e parasitas mortais, além de facilitar a mastigação e digestão. "Sem cozinhar, muitos vegetais têm pouca utilidade nutricional. A batata, por exemplo, simplesmente não pode ser digerida", diz Curnoe.

\section{Mudanças corporais}

Essa evolução de acordo com a alimentação permitiu, inclusive, cérebros maiores e mandíbulas menores. Nosso aparelho digestivo também mudou. $\mathrm{O}$ estômago humano é praticamente do mesmo tamanho do estômago de chimpanzés, mas o intestino delgado e o grosso são diferentes - nesse caso, temos o delgado maior e o grosso menor.

Isso porque alimentos ricos em amido (como a batata que, de novo, só é digerida corretamente ao ser cozida) nos permitem comer muito menos do que os macacos, explica Curnoe. 'Um chimpanzé não sobreviveria na selva com apenas três refeições por dia". 


\section{Por que a refeição se tornou social?}

Nossas cidades cresceram a partir da agricultura. E as pessoas foram se tornando especialistas em algum tipo de alimento - daí surgiram os padeiros, cozinheiros e chefs. $\mathrm{O}$ mercado e a economia também cresceram através da agricultura (quem cultivava milho trocava com quem cultivava tomate, e assim sucessivamente). No início das sociedades, as pessoas se reuniam levando suas especialidades, ou o que estava disponível em seu cultivo. Afinal, faz muito mais sentido compartilhar um pouco de cada alimento com o seu vizinho do que passar a vida toda comendo só batatas, sem inúmeros ingredientes essenciais.

Se hoje nós juntamos a família para cozinhar é por uma questão totalmente sociológica. "A alimentação é o centro das nossas celebrações e a usamos para socializar. Nossa espécie, mais do que qualquer outra, transformou a comida em algo especial", finaliza Curnoe.

Fernando Bumbeers (Revista Galileu)

Disponível em: www.revistagalileu.globo.com/Sociedade/noticia/2015/06/por-quegostamos-tanto-de-comida.html. Acesso em 20 de julho de 2015. 


\section{ANEXO B - Texto de divulgação científica (atividade 9)}

\section{O que são transtornos alimentares?}

Aquilo que você come - ou deixa de comer - pode se tornar um caso médico. Hábitos alimentares são considerados doentios quando interferem na saúde física e mental, deteriorando até as relações pessoais e profissionais da pessoa.

As causas desses distúrbios são muitas: vão da predisposição genética ao esforço para se adequar a padrões estéticos estabelecidos por figuras famosas. Por envolver fatores tão variados, a própria definição de transtorno alimentar é objeto de discussão: os únicos que recebem essa classificação da Organização Mundial da Saúde são a anorexia e a bulimia.

Descritas desde o antigo Egito, essas doenças se tornaram muito mais comuns nas últimas décadas - fala-se inclusive em uma epidemia, gerada pelo culto ao corpo perfeito. Exageros à parte, essas síndromes afetam hoje cerca de $1 \%$ da população mundial, sobretudo mulheres adolescentes e jovens.

Apesar de terem em comum a preocupação com o corpo, existem diferenças fundamentais entre os dois distúrbios. "Meninas com a norexia têm uma grave distorção de sua autoimagem, enxergando-se sempre muito mais gordas do que são", diz o psiquiatra Fábio Salzano, do Hospital das Clínicas de São Paulo. Na busca por emagrecer cada dia mais, elas simplesmente param de comer e viram esqueletos humanos. Para ser considerada anoréxica, é preciso ter um peso muito abaixo do estabelecido como saudável.

Já a distorção de imagem de uma bulímica é bem mais sutil. Elas não querem engordar, mas adoram comer. Têm ataques compulsivos seguidos de muita culpa que procuram aliviar provocando vômito ou tomando laxantes e diuréticos. "As meninas bulímicas têm, necessariamente, peso normal ou acima do normal", diz Alexandre Azevedo, também do HC paulistano.

Mas o universo dos des vios de comportamento envolvendo comida ultrapassa a bulimia e a anorexia. O cardápio de problemas vai da incapacidade de perceber quando o estômago está cheio até a fixação por alimentos exóticos. Os tratamentos variam de acordo com a doença, mas podem incluir remédios, psicoterapia e reeducação alimentar. 


\section{Menu indigesto}

\section{Ortorexia}

Os ortoréxicos têm verdadeira fixação por uma alimentação saudável, sem químicas, agrotóxicos nem aditivos. Eles são obsessivos pela escolha e preparo dos alimentos e tentam impor essa vida natureba a quem estiver por perto. O problema pode estar relacionado a transtornos obsessivos-compulsivos ou sinalizar um início de anorexia.

\section{Distúrbio alimentar relacionado ao sono (DARS)}

Quem sofre desse mal levanta no meio da noite para atacar a geladeira e acorda no dia seguinte sem se lembrar de quase nada do que se passou durante a madrugada. Essas pessoas, que comem normalmente durante o dia, são, muitas vezes, sonâmbulas. Cerca de $5 \%$ da população pode apresentar o problema, sendo a maioria mulheres.

\section{Síndrome de Prader-Willi}

A doença, que afeta 1 em cada 10 mil crianças. é associada a retardo mental. A criança apresenta um apetite insaciável e uma necessidade de comer constantemente alimentos de alto valor calórico. De origem genética, está diretamente relacionada à obesidade precoce. As complicações decorrentes do excesso de peso podem levar à morte.

\section{Síndrome do gourmet}

O portador dessa síndrome se preocupa em comer de forma fina e sofisticada, e isso inclui a compra, a preparação, a apresentação e o consumo de pratos elaborados ou exóticos. Muito rara - tem apenas 34 casos descritos - essa doença parece estar relacionada a lesões cerebrais. Já foi descrita em dois artigos publicados na literatura médica.

Marina Bessa e Soraia Gama (Revista Superinteressante)

Disponível em: www.super.abril.com.br/ciencia/o-que-sao-transtornos-alimentares. Acesso em 20 de julho de 2015. 

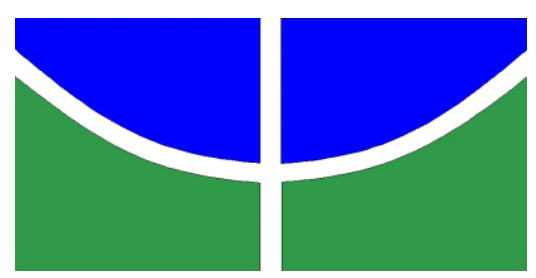

UNIVERSIDADE DE BRASÍLIA - UnB

Instituto de Ciências Biológicas

Instituto de Física

Instituto de Química

Faculdade UnB Planaltina

Programa de Pós-Graduação em Ensino de Ciências

Mestrado Profissional em Ensino de Ciências

\title{
ATIVIDADES DE ENSINO PARA A PROMOÇÃO DA ALIMENTAÇÃO SAUDÁVEL NA ESCOLA
}

\author{
LAYS BATISTA MARTINS LEITE
}

Brasilia, DF 


\section{SUMÁRIO}

APRESENTAÇÃO

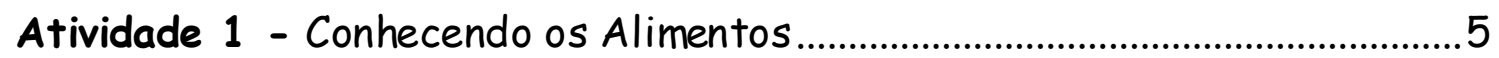

Atividade 2 - Os Alimentos no Cotidiano ......................................................... 9

Atividade 3 - A Relação da Alimentação com os Fatores Sociais ................... 12

Atividade 4 - A Alimentação nas Diversas Culturas ......................................... 16

Atividade 5 - Dietas Alimentares: Situações Problemas ................................ 18

Atividade 6 - A Influência da Mídia nas Dietas Alimentares ....................... 22

Atividade 7 - Fast Foods e os Impactos na Saúde Humana .......................... 25

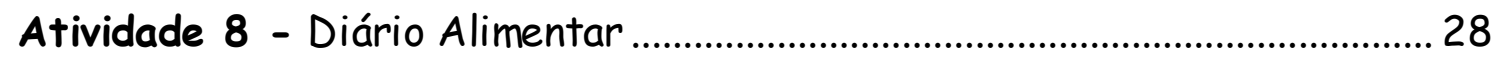

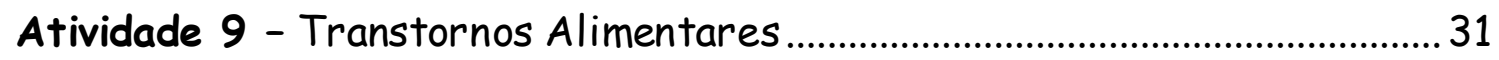

Atividade 10 - Compartilhando os Saberes Adquiridos ................................. 36

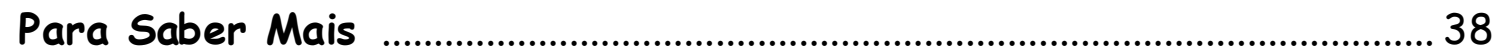

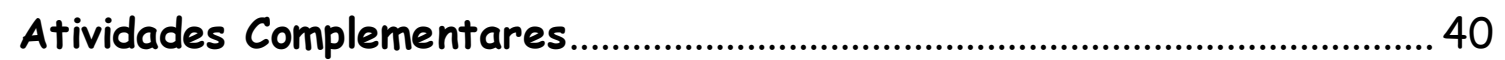

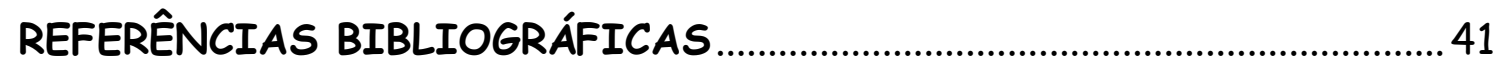




\section{APRESENTAÇÃO}

\section{Ao $\operatorname{professor}(\mathbf{a})$,}

Esta unidade didática foi escrita como proposta de ação profissional resultante da Dissertação realizada sob orientação da Prof. ${ }^{a}$ Dr. ${ }^{a}$ Mariana de Senzi Zancul e do Prof. Dr. Gerson de Souza Mól e apresentada à banca examinadora como requisito parcial à obtenção do Título de Mestre em Ensino de Ciências pelo Programa de PósGraduação em Ensino de Ciências da Universidade de Brasilia.

O presente material, denominado: Atividades de Ensino para a Promoção da Alime ntação Saudável na Escola tem como objetivo gerar subsídios que auxiliem professores no trabalho com seus alunos adolescentes da Educação Básica acerca do tema destacado. Assim, esta unidade didática é composta por estratégias pedagógicas que possuem a finalidade de contribuir para a formação crítica dos estudantes, buscando envolvê-los em seu processo de ensino-aprendizagem a partir de propostas problematizadoras. Essas estratégias visam à reflexão do educando mediante suas escolhas alimentícias, além de ressaltar a relação da alimentação com os fatores sociais, culturais e psicológicos.

A implantação de atividades de educação alimentar na escola fornece condições que possibilitam incentivar os estudantes a se responsabilizarem por um comportamento alimentar no qual se enquadram aos aspectos saudáveis (MARTINS; WALDER; RUBIATTI, 2010). Essa proposta se justifica porque os adolescentes, em sua maioria, passam grande parte de seu tempo no ambiente escolar. Nesse espaço esses sujeitos são influenciados por diferentes opções alimentares de seus colegas e todo contexto do que é socialmente aceito (GAMBARDELLA; FRUTUOSO; FRANCH, 1999).

Partindo do pressuposto que a educação alimentar não se baseia na transposição de conteúdos e não perpassa as questões unicamente biológicas entrando no campo dos assuntos sociais, culturais e psicológicos (DOMENE, 2008; GAVIDIA, 2009), esta proposta didática foi elaborada a partir das seguintes premissas:

I. Utilização de temas significativos para os alunos.

II. Propostas que vislumbrem abordagens problematizadoras como eixos norteadores, possibilitando momentos de reflexão. 
III. Buscar o desenvolvimento de uma visão crítica que propulsione a resolução de problemas nutricionais de forma criativa e inovadora.

IV. Atividades viáveis e que viabilizem a sua execução, além da utilização de materiais facilmente encontrados pelo professor.

V. Interdisciplinaridade e integração entre diferentes disciplinas escolares (Biologia, Ciências Naturais e Química).

A colaboração pedagógica deste trabalho consiste em prover meios que agenciem a formação consciente de nossos estudantes, ancorando-se na concepção de que os assuntos intrínsecos ao contexto escolar devem se aproximar da realidade do aluno, para que este tenha compreensão de suas escolhas e atue coerentemente, ocasionando assim o desenvolvimento de sua autonomia de pensamento (FREIRE, 1996).

As atividades didáticas encontradas neste material foram em sua maioria elaboradas pela autora, as demais são adaptações de outras fontes. Com essa proposição pretende-se contribuir para o trabalho docente, atrelando assuntos que permeiam a educação alimentar, sendo assim as atividades sugeridas neste material estão detalhadas de modo a direcionar a atuação do educador em sala de aula, estando ao critério do professor estabelecer à ordem cronológica e adaptação destas.

Lays Batista Martins Leite

Programa de Pós-Graduação em Ensino de Ciências

Mestrado em Ensino de Ciências

Universidade de Brasilia 


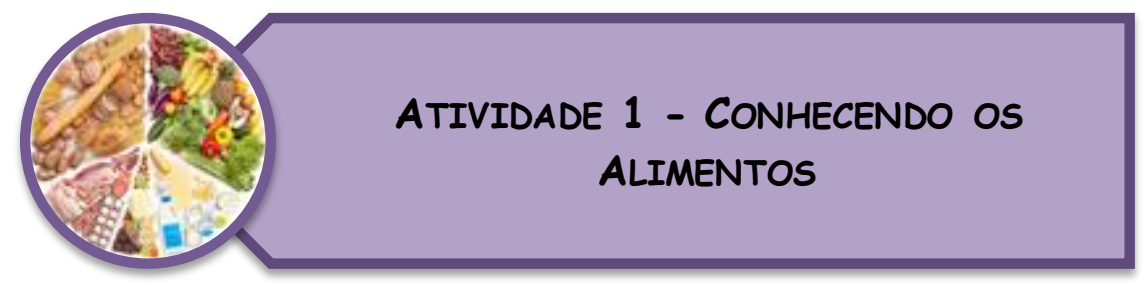

A relação que os indivíduos possuem com os alimentos irá influenciar no seu consumo diário. Em muitos casos as pessoas preferem aderir à ingestão de alimentos industrializados pela praticidade e comodidade, e dispensam o conhecimento da procedência daquele determinado alimento. Inclusive, ainda há aqueles que classificam os alimentos em bons ou ruins, desenvolvendo deste modo uma relação complicada com a alimentação (DERAM, 2014).

A atividade ${ }^{1}$ a seguir propõe que o estudante faça o manuseio de alimentos pertencentes a distintos grupos alimentares, visando fortificar a concepção de que comer não se configura apenas em um ato essencial para sobrevivência, mas também se relaciona as questões psicológicas e sociais. Assim, almeja-se sensibilizar os educandos a se interessarem pela origem do que consomem, além de informá-los sobre a importância nutricional de cada alimento apresentado.

\section{Objetivos}

Identificar e nomear alimentos de diversos grupos.

Explorar as formas, texturas, cores, sabores, cheiros e derivados dos alimentos.

Valorizar os recursos alimentares naturais existentes.

Promover o contato com novos alimentos.

\footnotetext{
${ }^{1}$ Atividade adaptada. Referência: Rodrigues, L. P. F. Guia de promoção da alimentação saudável e sustentável para escolas. Brasília: Universidade de Brasília - Decanato de Extensão, 2011.
} 


\section{Materiais Necessários}

Alimentos pertencentes a diferentes grupos alimentares.

Impressão da tabela (apêndice 1). Caso essa possibilidade seja inexistente, solicite que os alunos a registrem no caderno.

\section{Sugestões de Alimentos:}

Chocolate, leite, ovos, carne, azeite, abacate, amendoim, banana, ameixa, kiwi, agrião, erva doce, rabanete, hortelã, macarrão, pão, arroz, granola, berinjela, pepino, brócolis, cenoura, quiabo, ervilha.

\section{Descrição da Atividade de Ensino}

1. Selecione antecipadamente alimentos de distintos grupos alimentares, como: doces (ex.: chocolate); lácteos e derivados (ex.: leite, queijo); carnes e ovos; oleaginosas e azeite (ex.: azeite de oliva, abacate, óleo de soja); frutos secos e sementes (ex.: amendoim, nozes, castanha de caju); frutas (ex.: banana, ameixa, kiwi, caqui, mamão); verduras e hortaliças (ex.: hortelã, agrião, couve flor, erva doce, tomilho, rabanete); cereais, integrais, massas (ex.: macarrão, pão, linhaça, arroz, granola); e, legumes, soja e derivados (berinjela, pepino, brócolis, cenoura, tomate, quiabo, lentilha, ervilha, feijão).

2. Enumere os alimentos e organize-os em uma mesa. Proponha que os alunos os manipule, visando identificá-los. Permita que os estudantes troquem informações.

3. Distribua uma tabela (apêndice 1) para os discentes, com as seguintes considerações: a) nome do alimento; b) consumo do determinado alimento; c) satisfação de se alimentar do referido alimento; e d) frequência que consome este alimento. Peça para que os alunos preencham a tabela conforme as percepções que possuem acerca de cada alimento disposto. 
4. Discuta com os educandos as questões propostas na tabela e solicite que eles destaquem as percepções adquiridas ao longo da atividade. A discussão deverá estar relacionada com a valorização dos recursos alimentares naturais e a inserção de alimentos saudáveis nas dietas dos adolescentes.

Duração Estimada: 40 minutos.

\section{Avaliação}

Observe a interação dos discentes no decorrer da aula com a atividade proposta, levando em consideração o empenho em participar dela.

\section{Texto de Apoio}

BRASIL. Ministério da Saúde. Secretaria de Atenção à Saúde. Departamento de Atenção Básica. Guia alimentar para a população brasileira / Ministério da Saúde, Secretaria de Atenção à Saúde, Departamento de Atenção Básica. - 2. ed. - Brasília : Ministério da Saúde, 2014. 
Apêndice 1 - Tabela para Atividade

\begin{tabular}{|c|c|c|c|c|}
\hline $\begin{array}{c}\text { Núme ro do } \\
\text { Alimento }\end{array}$ & $\begin{array}{l}\text { Qual o nome do } \\
\text { alimento? }\end{array}$ & $\begin{array}{c}\text { Você } \\
\text { Come? }\end{array}$ & $\begin{array}{c}\text { Você } \\
\text { Gosta? }\end{array}$ & Qual fre quência você o consome? \\
\hline 1 & & & & \\
\hline 2 & & & & \\
\hline 3 & & & & \\
\hline 4 & & & & \\
\hline 5 & & & & \\
\hline 6 & & & & \\
\hline 7 & & & & \\
\hline 8 & & & & \\
\hline 9 & & & & \\
\hline 10 & & & & \\
\hline 11 & & & & \\
\hline 12 & & & & \\
\hline 13 & & & & \\
\hline 14 & & & & \\
\hline 15 & & & & \\
\hline 16 & & & & \\
\hline 17 & & & & \\
\hline 18 & & & & \\
\hline 19 & & & & \\
\hline 20 & & & & \\
\hline
\end{tabular}




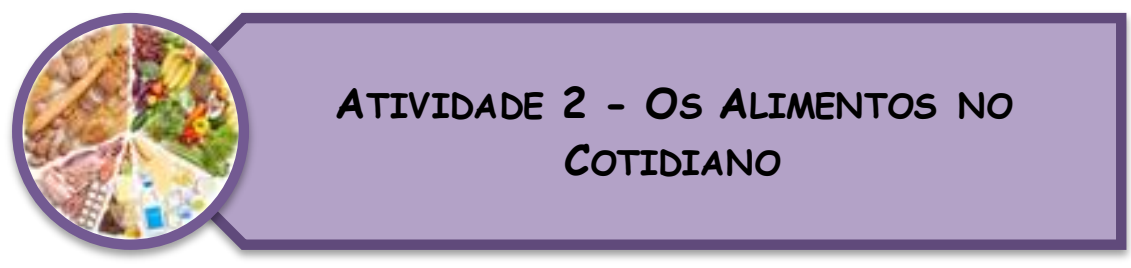

A alimentação é um traço individual de cada ser humano, é um fator que ressalta essencialmente a singularidade dos sujeitos na sociedade, uma vez que a relação com a comida é distinta entre os diversos grupos e pessoas. Para além das questões nutricionais, a alimentação possui sua contribuição para os aspectos culturais, assim como se torna um ato de construção da identidade, é também reflexo da influência social (LOUREIRO, 2004).

A atividade 2 disposta neste espaço, envolve o resgate de valores intrínsecos a alimentação, bem como a expansão da cultura alimentar e direito a alimentação. Para a concretização desta ação, os alunos deverão se envolver em uma ação contínua e participativa de aprendizado, sendo assim estes estarão incumbidos de realizar pesquisas em relação a poemas, músicas e textos que abordem considerações sobre alimentação, para que posteriormente possam divulgar o trabalho em um mural que será visualizado por todos que fazem parte do referido ambiente escolar.

\section{Objetivos}

Expandir a cultura alimentar.

Resgatar valores culturais relativos à alimentação.

Discutir questões intrínsecas ao direto à alimentação.

Identificar a relação que os estudantes possuem com os alimentos.

\section{M ateriais Necessários}

- Cartolinas coloridas.

Pinceis atômico.

* Lápis de cor. 
Tesoura.

* Cola.

Revistas e jornais.

\section{Descrição da Atividade de Ensino}

1. Na aula anterior, peça para que os discentes pesquisem acerca de músicas, textos e poemas, cujo tema seja alimentação.

2. Solicite que os alunos exponham os resultados de suas pesquisas para toda a turma.

3. Com base na exibição das pesquisas, peça para que a turma elabore um mural com gravuras e os com os textos, poemas e músicas partilhados.

4. Discutir aspectos inerentes ao direito à alimentação.

Duração Estimada: 70 minutos.

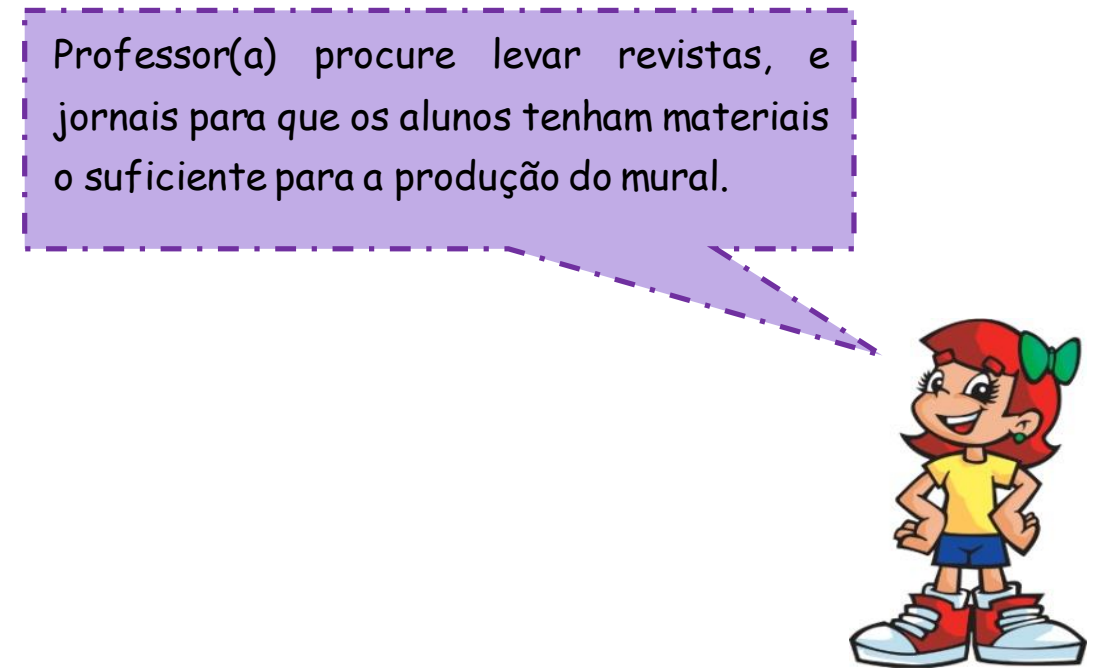

Figura 1. Disponível em: www.facesblogger.com.br. Acesso em: 16 de junho de 2015. 


\section{Avaliação}

Analise a desenvoltura dos estudantes em relação à produção do mural, além de observar sua participação no momento da exposição da pesquisa realizada ao longo da atividade.

\section{Sugestão}

Professor(a) participe desta atividade junto com os seus alunos, sendo assim, realize sua pesquisa e exponha para turma o que foi encontrado. 


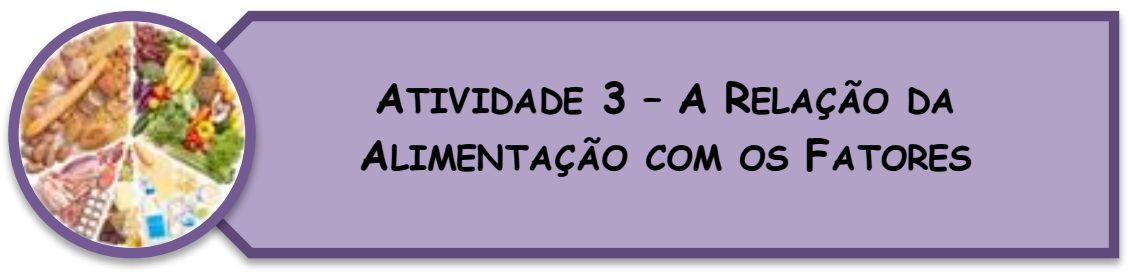

A alimentação humana possui uma forte relação com o fator social, uma vez que, os alimentos "carregam significações culturais, a fetivas e comportamentais que não devem ser desprezadas" (COSTA, 2009).

Nesta ação o professor irá utilizar um texto de divulgação científica disponibilizado neste material pedagógico (apêndice 1), com o intuito de explanar acerca da relação entre a alimentação e os fatores sociais, o seguinte texto deverá ser distribuído para os alunos, em um primeiro momento. Posteriormente, o educador irá propor que os discentes desenhem ou escrevam histórias, manifestações culturais e mitos populares que conhecem sobre a alimentação.

\section{Objetivo}

Refletir acerca da relação entre a alimentação e as questões sociais.

\section{Materiais Necessários}

- Impressão do texto de divulgação científica (apêndice 1).

Folhas de papel ofício coloridas.

Lápis de cor.

- Canetas esferográficas. 


\section{Descrição da Atividade de Ensino}

1. Organize a turma em um círculo e distribua o texto de divulgação científica Porque gostamos tanto de comida? (apêndice 1).

2. Solicite que os alunos realizem a leitura e anotem as principais considerações por eles identificadas no texto.

3. Discuta com os alunos sobre a importância da alimentação e sua relação com os fatores sociais.

4. Em seguida peça para que os discentes relatem por meio de desenhos: histórias, manifestações culturais e mitos populares que tenham relação com a alimentação ${ }^{2}$.

5. Disponha um espaço para que os estudantes exponham seus relatos, e posteriormente realize a conclusão da atividade, explanando acerca do que foi enfatizado ao longo da proposta.

Duração Estimada: 60 minutos.

\section{Avaliação}

Avalie a participação dos estudantes na discussão a ser realizada, e observe os relatos produzidos durante a atividade.

\footnotetext{
${ }^{2}$ Proposta adaptada. Disponível em: http://www.mds.gov.br/segurancaalimentar/educacao-alimentar-enutricional/caderno,P20de,P20atividades,P20co mpleto,P20ed itado.pdf.pages peed.ce.f65tX-1T3j.pdf. Acesso em 22 de julho de 2015.
} 


\title{
Apêndice 1 - Texto de Divulgação Científica
}

\section{Porque gostamos tanto de comida?}

\begin{abstract}
Muito além da resposta "porque comer é bom": somos a única espécie que cultiva e
\end{abstract} cozinha alimentos

Ah, a comida! Todo mundo precisa de comida para sobreviver, mas por que continuamos procurando novas maneiras de preparar pratos cada vez mais diferentes e saborosos?

Os hábitos alimentares dos seres humanos têm causado grandes mudanças evolutivas no corpo. O biólogo evolucionista da Universidade de New South Wales, Darren Curnoe, explica que cozinhar é uma atividade totalmente enraizada em nossa existência. "Somos a única espécie que cultiva e cozinha os alimentos".

Cozinhamos - e não é de hoje. Bem antes da agricultura, que data de 10 mil anos atrás, já existiam registros de cozimento de alimentos. Cozinhar deu uma vantagem enorme aos nossos ancestrais em relação às outras espécies afinal os alimentos ficavam livres de bactérias e parasitas mortais, além de facilitar a mastigação e digestão. "Se m cozinhar, muitos vegetais têm pouca utilidade nutricional. A batata, por exemplo, simplesmente não pode ser digerida”, diz Curnoe.

\section{Mudanças corporais}

Essa evolução de acordo com a alimentação permitiu, inclusive, cérebros maiores e mandíbulas menores. Nosso aparelho digestivo também mudou. O estômago humano é praticamente do mesmo tamanho do estômago de chimpanzés, mas o intestino delgado e grosso são diferentes - nesse caso, temos o delgado maior e o grosso menor.

Isso porque alimentos ricos em amido (como a batata que, de novo, só é digerida corretamente ao ser cozida) nos permitem comer muito menos do que os macacos, 
explica Curnoe. 'Um chimpanzé não sobreviveria na selva com apenas três refeições por dia".

\section{Por que a refeição se tornou social?}

Nossas cidades cresceram a partir da agricultura. E as pessoas foram se tornando especialistas em algum tipo de alimento - daí surgiram os padeiros, cozinheiros e chefs. $\mathrm{O}$ mercado e a economia também cresceram através da agricultura (quem cultivava milho trocava com quem cultivava tomate, e assim sucessivamente). No início das sociedades, as pessoas se reuniam levando suas especialidades, ou o que estava disponível em seu cultivo. Afinal, faz muito mais sentido compartilhar um pouco de cada alimento com o seu vizinho do que passar a vida toda comendo só batatas, sem inúmeros ingredientes essenciais.

Se hoje nós juntamos a família para cozinhar é por uma questão totalmente sociológica. "A alimentação é o centro das nossas celebrações e a usamos para socializar. Nossa espécie, mais do que qualquer outra, transformou a comida em algo especial", finaliza Curnoe.

Fernando Bumbeers (Revista Galileu)

Disponível em: www.revistagalileu.globo.com/Sociedade/noticia/2015/06/por-quegostamos-tanto-de-comida.html. Acesso em 20 de julho de 2015. 


\section{ATIVIDADE 4 - A ALIMENTAÇÃO NAS DIVERSAS CULTURAS}

Para que a educação alimentar seja instituída efetivamente no meio escolar é preciso edificar um espaço que valoriza a troca de experiências e constrói uma relação significativa entre saber popular e o científico (GOMES; FONSECA, 2013). Para Barbosa et al (2012, p. 940) "não se pode desenhar somente uma prática centrada na relação alimentos e seus nutrientes", com o intuito de resgatar os fatores culturais na formação dos hábitos alimentares, essa atividade terá como propósito a realização de uma investigação sobre a alimentação em distintos países ou regiões (a critério do professor (a)). Esta ação permitirá que os alunos compartilhem os resultados de sua pesquisa por meio da apresentação dos alimentos encontrados em culturas distintas para os demais discentes integrantes da turma.

\section{Objetivos}

Relacionar a manifestação da cultura com os hábitos alimentares de determinados grupos.

> Pesquisar e refletir acerca dos padrões alimentares em diferentes povos.

Valorizar os hábitos alimentares locais.

\section{M ateriais Necessários}

Fontes de pesquisa: livros, internet, cartilhas, etc.

Alimentos a serem selecionados pelos educandos. 


\section{Descrição da Atividade de Ensino}

1. Organize a turma em grupos de cinco discentes. Peça para que os educandos realizem uma investigação acerca da alimentação em culturas (mundiais ou regionais) distintas, em seguida solicite que eles registrem essas informações, buscando solucionar a seguinte questão: A cultura influência na formação de hábitos alimentares? Como?

2. Discuta com os alunos a importância da cultura na promoção da alimentação saudável. Além disso, peça para que eles exponham suas percepções acerca da pesquisa realizada.

3. Para concluir a atividade, proponha que os alunos levem um prato típico de um país ou região de sua escolha.

Duração Estimada: 90 minutos.

\section{Avaliação}

Para avaliar os alunos, peça para que eles elaborarem um relatório sobre suas percepções ao longo da proposta desenvolvida. 


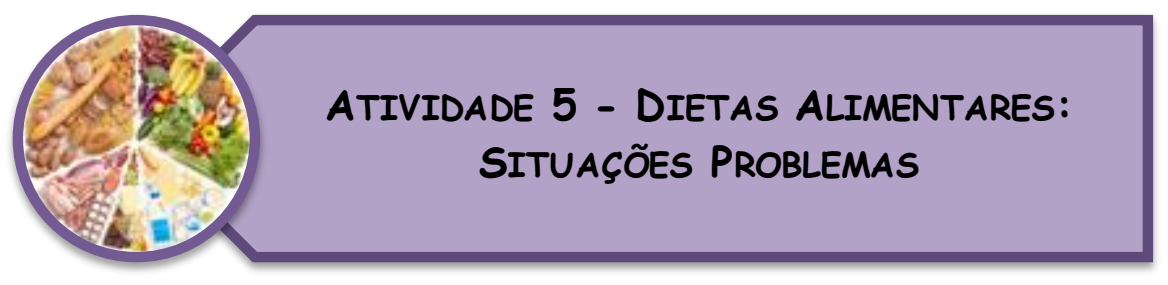

As dietas alimentares com o objetivo de emagrecimento começaram a surgir a partir do século XX (SANTOS, 2010). A democratização das informações e as pressões sociais tornaram as dietas restritivas extremamente presentes nas mídias, deste modo, encontram-se nos meios de comunicação (revistas, jornais, blogs, redes sociais, vídeos, etc.) dietas variadas que na maioria dos casos não possuem antecedentes científicos e apresentam efeitos passageiros, tornando vulnerável a saúde do indivíduo.

$\mathrm{Na}$ atividade apresentada a seguir, serão expostas para os alunos situações problemas que vislumbram contextualizar episódios que englobem o tema dietas alimentares. A proposta envolve questões que comumente acontecem no cotidiano, comentários que geralmente ouvimos de amigos, colegas de trabalho e de familiares, em relação as suas respectivas escolhas alimentares e que consequentemente influenciam os fatores sociais e psicológicos.

\section{Objetivos}

Identificar as consequências das dietas alimentares para o organismo humano.

Discutir sobre as várias dietas alimentares presentes na mídia.

Promover uma reflexão sobre os padrões estéticos definidos pela sociedade.

\section{M ateriais Necessários}

Impressão das situações problemas (apêndice 1).

Folhas de papel ofício coloridas.

* Pinceis atômico.

* Lápis de cor. 
Cola.

Tesoura.

\section{Descrição da Atividade de Ensino}

1. Organize a turma em 3 grupos e distribua as situações problemas sobre as dietas alimentares (apêndice 1).

2. Solicite que os alunos respondam aos questionamentos dispostos nas situações problemas para que posteriormente possam expor para a turma.

3. Promova uma discussão acerca das diversas dietas alimentares restritivas presentes nos meios de comunicação, como internet, revistas e televisão (anote no quadro as dietas que os educandos conhecem). Além disso, procure enfatizar aspectos relacionados aos padrões estéticos estabelecidos pela sociedade.

4. Peça para que os discentes ainda em grupos elaborem cartazes com slogans e frases de impactos sobre as dietas alimentares.

Duração Estimada: 90 minutos.

\section{Avaliação}

Observe as respostas salientadas pelos grupos e avalie os cartazes produzidos pelos alunos.

\section{Informe-se sobre os Assunto}

O livro O peso das dietas da autora Sophie Deram, é um excelente subsídio para auxiliar na discussão a ser realizada na aula, este corrobora acerca da importância de não fazer dietas restritivas com o intuito de emagrecimento, uma vez que, estas apresentam apenas um efeito momentâneo e prejudicial à saúde. 


\section{Sugestão}

Professor (a) aproveite os questionamentos das situações problemas para destacar pontos relacionados à obesidade e transtornos alimentares. 


\section{Apêndice 1 - Situações Problemas sobre Dietas Alimentares}

\section{Situação 1}

Layla é uma adolescente de quinze anos, todos os dias ela sofre bullying na escola devido ao seu excesso de peso. Ela é uma garota com autoestima baixa e se sente bastante triste com os comentários realizados pelos colegas. Com intuito de emagrecer rapidamente, Layla resolveu aderir a uma dieta alimentar, na qual ela só irá ingerir sopa e água por 40 dias. Vocês acham que esse tipo de dieta traz benefícios para a saúde desta adolescente? Vocês já fizeram alguma dieta restritiva como a que Layla pretende realizar? Quais as consequências esse tipo de dieta pode gerar para a saúde da adolescente? Vocês acham que o excesso de peso é uma doença? Qual a medida correta Layla pode recorrer para emagrecer?

\section{Situação 2}

Júnior tem dezessete anos e há um ano exercita musculação diariamente. Desde então, ele tem uma dieta bastante rígida, consumindo apenas proteínas, a adoção desta dieta surgiu com o objetivo de adquirir mass a muscular. Vocês acham a medida assentida por Júnior é adequada para sua saúde? Vocês conhecem pessoas que possuem esse tipo de dieta? Quais as consequências desse tipo de dieta para a saúde de Júnior? Existem outros meios para se adquirir massa muscular?

\section{Situação 3}

Evelyn desde a infância sonha em ser modelo, no entanto, algumas restrições em sua alimentação devem ser adotas para manter o seu peso. Atualmente Evelyn faz poucas refeições diárias e muitas vezes se priva totalmente dos alimentos. Vocês acham a postura de Evelyn saudável em relação a sua alimentação? Quais os danos à dieta aderida por ela pode causar a sua saúde? Quais outros métodos considerados saudáveis ela pode adotar para manter o peso? 


\section{ATIVIDADE 6 - A INFLUÊNCIA DA MÍDIA NAS DIETAS ALIMENTARES}

A mídia é um componente extremamente presente na vida dos estudantes de qualquer faixa etária, Moura (2010, p. 114) corrobora que a [...] "a mídia, nas suas múltiplas formas, está entre aquelas que mais rapidamente estão assumindo papel central na socialização de crianças e jovens".

Partindo desse pressuposto, destaca-se a importância de um direcionamento coerente por parte da escola em relação a vários assuntos abordados pelos meios de comunicação, entre eles os padrões alimentares que geralmente são impostos. Nessa atividade o professor (a) irá discutir os seguintes aspectos buscando desenvolver o pensamento crítico e reflexivo dos discentes.

\section{Objetivos}

Realizar uma pesquisa sobre as considerações vinculadas a alimentação na mídia.

Elaborar um jornal científico com as informações encontradas pelos educandos.

$>$ Discutir sobre os diversos padrões alimentares disponibilizados pela mídia.

$>$ Refletir sobre os hábitos alimentares impostos pelo marketing.

\section{M ateriais Necessários}

Papel ofício.

Pinceis atômicos.

* Canetas esferográficas.

Cola.

Tesoura. 


\section{Descrição da Atividade de Ensino}

1. Inicialmente divida a turma em grupos (3 ou 4 estudantes). Solicite que os grupos realizem uma pesquisa que mostre a forma de como à alimentação é arremetida nos blogs, redes sociais, revistas, jornais, sites e demais meios de comunicação.

2. Requeira que os discentes levem para a aula o material encontrado, para que posteriormente possam montar um jornal com as informações.

3. Para a conclusão da atividade o professor (a) deverá promover uma discussão 3dos principais pontos enfatizados pelos estudantes, ressaltando principalmente que a maioria das informações coletadas é errônea e raramente possuem precedentes científicos.

\section{Duração Estimada: 90 minutos.}

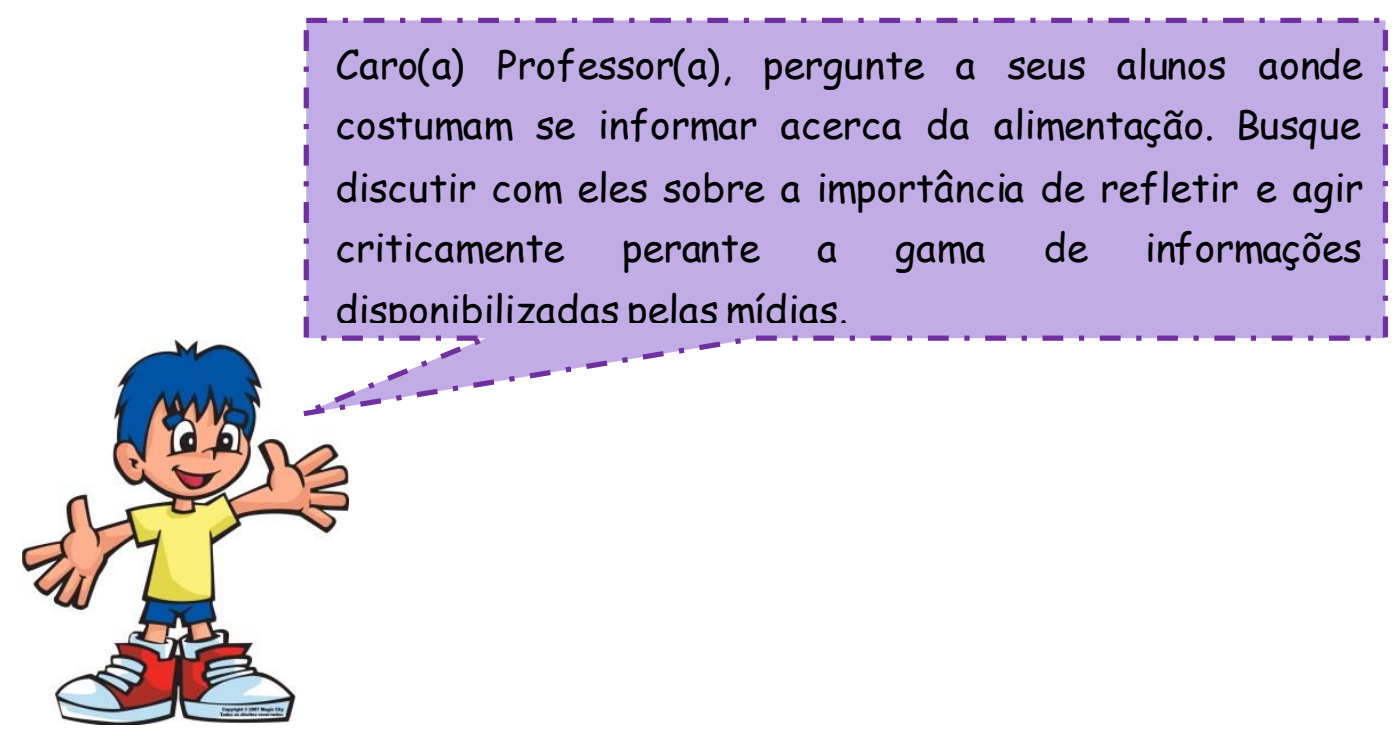

Figura 2. Disponível em: www.caldeiraodhistorias.blogs pot.com.br. Acesso em: 16 de junho de 2015. 


\section{Avaliação}

Observe a interação e interesse do grupo em realizar as atividades propostas, além disso, procure notar a participação individual dos discentes durante a discussão. 


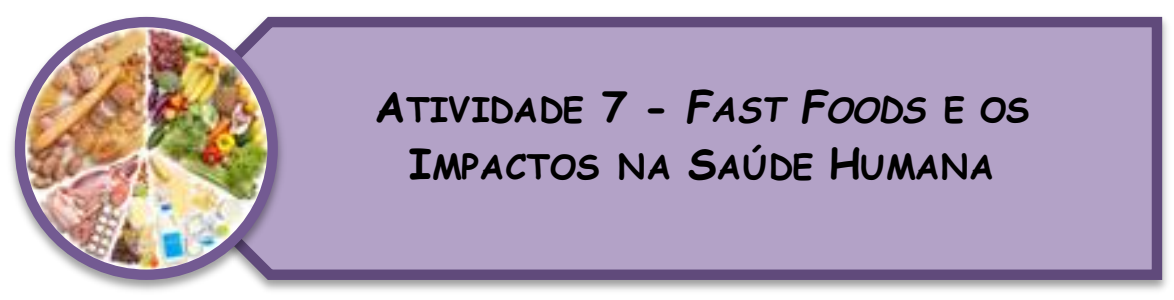

A cultura de alimentação rápida veio se solidificando nos últimos anos pelo mundo, em consequência da vida moderna. Sendo assim, as empresas alimentícias que oferecem os serviços de fast food (comida rápida) são opções práticas e cômodas para a maioria das pessoas. Ortigoza (1997, p. 4) enfatiza que "o fast food impõe seu ritmo ao tempo e ao espaço dedicados à alimentação, que passam a entrar em sintonia com as novas exigências da sociedade. A padronização torna-se condição para a crescente aceleração do movimento dentro das cidades". No entanto, de modo geral, não são considerados os prejuízos que esse tipo de alimento pode desenvolver no organismo se ingeridos constantemente. Tais danos podem contribuir para o desenvolvimento de doenças, como a hipertensão, diabetes e a obesidade.

Para ressaltar os aspectos mencionados, a atividade a seguir foi distribuída em duas etapas, a primeira envolve a demonstração da quantidade de açúcar encontrada em bebidas industrializadas, como refrigerantes e sucos e a segunda etapa engloba a reprodução do documentário americano Super Size me-A dieta do Palhaço.

\section{Objetivos}

Observar a quantidade de açúcar presente em refrigerantes e sucos industrializados.

Explanar e discutir sobre os prejuízos que esses alimentos podem ocasionar no organismo, se consumidos constantemente. 


\section{Materiais Necessários}

* Alimentos provindos de lanchonetes de Fast Food (Sugestão: batata frita).

* Refrigerantes e sucos industrializados.

Açúcar.

Balança.

* Recipientes transparentes.

Datashow ou televisão.

Computador.

Ampliadores de som.

\section{Descrição da Atividade de Ensino}

\section{Etapa 1: Quantidade de açúcar nos refrigerantes e sucos industrializados ${ }^{3}$}

1. Faça a seleção de refrigerantes e sucos industrializados de marcas diferentes.

2. Verifique no rótulo a quantidade de açúcar em cada bebida escolhida.

3. Distribua em recipientes transparentes com auxílio de uma balança meça a quantia de açúcar indicada nos rótulos das respectivas bebidas.

4. Comente com os alunos os danos que podem ser gerados no organismo, devido ao consumo exagerado de açúcar.

Duração Estimada: 30 minutos.

\section{Etapa 2: Documentário Super Size me}

1. Reproduza o documentário Super Size me - A dieta do palhaço.

\footnotetext{
${ }^{3}$ Atividade encontrada em: www.manualdo mundo.com.br/2012/07/descubra-a-quantidade-de-acucar-norefrigerante. Acesso em: 19 de julho de 2015.
} 
2. Discuta com os educandos os prejuízos causados a saúde devido ao consumo frequente dos alimentos destacados ao longo das três etapas desta atividade.

3. Solicite que os discentes elaborem um texto relatando o que observaram nas demonstrações buscando atrelar essas concepções ao documentário.

Duração Estimada: 160 minutos.

O documentário Super Size me - A dieta do palhaço, trata-se de um experimento realizado por um cineasta que por trinta dias só consumiu alimentos provindos de

Fast Food. Após este período, ele constatou os prejuízos que esses alimentos ocasionaram ao seu organismo.

Link para o documentário: www.youtube.com/watch?v=zEIRrJDO8zI

\section{Avaliação}

Verifique primordialmente o interesse dos alunos, além disso, o texto a ser elaborado será ofeedback do trabalho realizado em sala de aula.

\section{Texto de Apoio}

FISCHLER, C. A "McDonaldização" dos costumes. In: FLANDRIN, J. L.; MONTANARI, M. História da alimentação. P. 841-862. São Paulo: Estação Liberdade, 1998. 


\section{ATIVIDADE 8 - DIÁRIO ALIMENTAR}

Os hábitos alimentares são formados a partir de diversos fatores, estes englobam as questões culturais sociais e psicológicas. De acordo Contreras e Gracia (2011, p. 304) corroboram que "[...] a comida não é apenas uma necessidade biológica, mas suas funções sociais e psicológicas são muito significativas".

A atividade descrita a seguir envolve a produção de um diário alimentar, no qual os alunos deverão destacar o seu consumo alimentar diário por um determinado período de dias - esse prazo pode ser limitado conforme o andamento do trabalho docente - essa proposta tem como intuito fazer com que os alunos reflitam acerca dos hábitos alimentares diários, visando ressaltar a partir de então, fatores que possam contribuir para a formação de uma dieta saudável.

\section{Objetivo}

Conhecer e refletir acerca da alimentação diária adquirida.

Discutir estratégias que podem tornar a alimentação dos alunos mais saudável.

\section{Materiais Necessários}

Folhas de papel ofício.

* Canetas esferográficas. 


\section{Descrição da Atividade de Ensino}

1. Solicite que os estudantes elaborem um diário sobre sua alimentação cotidiana, relatando porções, quantidade de refeições diárias e quais os alimentos ingeridos.

2. A partir da análise das anotações, discuta com os alunos se eles consideram a suas respectivas alimentações cotidianas adequadas, para manter-se saudável.

3. Com auxílio do Guia Alimentar para a População Brasileira (p.125), destaque estratégias que podem favorecer a promoção de uma alimentação adequada e saudável destes educandos.

Duração Estimada: 40 minutos.

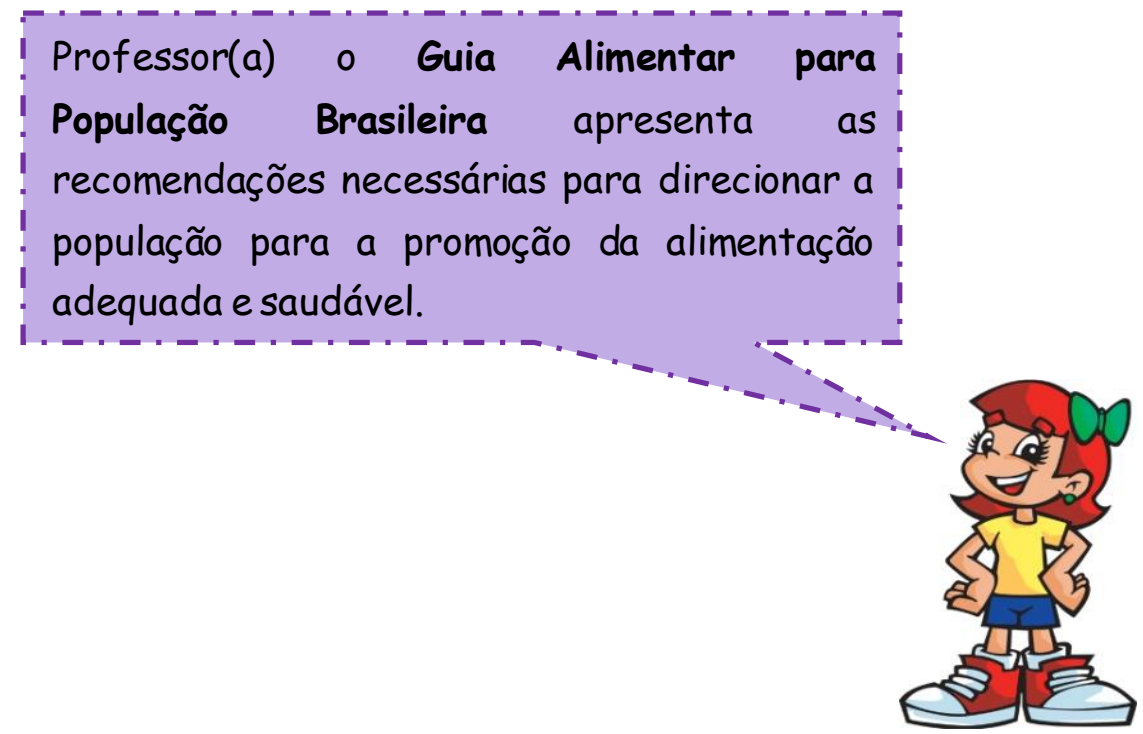

Figura 3. Disponível em: www.facesblogger.com.br. Acesso em: 16 de junho de 2015. 


\section{Avaliação}

Procure verificar se os alunos estão realizando o que é solicitado, avalie-os com base na produção do diário alimentar.

\section{Texto de Apoio}

BRASIL. Ministério da Saúde. Secretaria de Atenção à Saúde. Departamento de Atenção Básica. Guia alimentar para a população brasileira / Ministério da Saúde, Secretaria de Atenção à Saúde, Departamento de Atenção Básica. - 2. ed. - Brasília : Ministério da Saúde, 2014. 


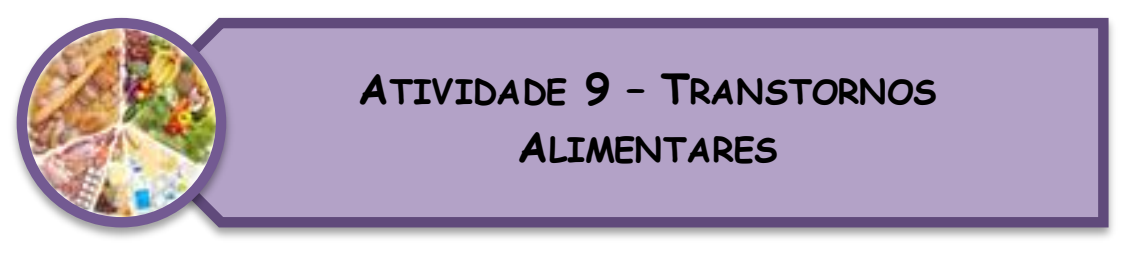

Os transtornos alimentares apresentam seus primeiros sintomas geralmente na adolescência e na infância, em maior índice em pessoas do sexo feminino (APPOLINÁRIO; CLAUDINO, 2000). Deste modo, estes transtornos estão associados com o comportamento alimentar adquirido pelos indivíduos, e outros aspectos que envolvem a formação da identidade de cada sujeito. Para Loureiro (2004, p. 43) a alimentação "traduz as condições de vida de cada um, o contexto em que se move a cultura que perfilha. Sendo um traço de identidade, é também o reflexo das pressões sociais".

A proposta desta atividade vislumbra discutir as premissas intrínsecas aos transtornos ao alimentares com auxílio de um texto de divulgação científica, este texto aborda sobre os tipos de transtornos alimentares, e a cargo do professor fica a explanação acerca da prevenção dos transtornos alimentares.

\section{Objetivos}

Conhecer os transtornos alimentares existentes.

Identificar meios de prevenção aos transtornos alimentares.

$>$ Gerar uma discussão sobre o assunto, apoiando-se no texto de divulgação científica disponibilizado.

$>$ Produzir cartazes que explanem acerca da prevenção de tais problemáticas.

\section{M ateriais Necessário}

Impressão do texto de divulgação científica (apêndice 1).

Cartolinas.

Pinceis atômicos. 
Lápis de cor.

Canetas esferográficas.

\section{Descrição da Atividade de Ensino}

1. Distribua o texto de divulgação científica "O que são transtornos alimentares?" (apêndice 1) para os alunos, solicite que eles realizem a leitura.

2. Discuta com os discentes os principais pontos destacados no texto, buscando denotar os métodos que podem prevenir os transtornos alimentares.

3. Posteriormente organize os educandos em grupos e peça que eles elaborem cartazes que relatem suas percepções acerca do assunto e as maneiras de prevenção desses distúrbios.

4. Peça para que os estudantes apresentem suas considerações para toda a turma.

Duração Estimada: 60 minutos.

\section{Avaliação}

Os discentes serão avaliados conforme o seu desempenho em realizar a produção do cartaz, assim como a participação na discussão do texto disponibilizado.

\section{Texto de Apoio}

APPOlinÁRIO, J. C.; ClAUdinO, A. M. Transtornos Alimentares. Rev. Bras Psiquiatr, v. 22, p. 28-31, 2000. Disponível em: www.scielo.br/pdf/rbp/v22s2/3793.pdf. Acesso em 20 de julho de 2015. 


\section{Informe-se sobre o assunto}

\section{Sites:}

www.disturbiosalimentares.com/noticias/prevencao-de-disturbios-alimentares-dicas

www.ind icedesaude.com/artigos_ver.php?id=1714

www.bbc.com/portuguese/noticias/2015/02/150203_transtornos_alimentares_infancia_ pai

\section{Sugestão}

Professor (a) você pode organizar um mural com os cartazes produzidos pelos alunos, fazendo com que as informações destacadas fiquem visíveis para toda a escola. 


\section{Apêndice 1 - Texto de Divulgação Científica}

\section{O que são transtornos alimentares?}

Aquilo que você come - ou deixa de comer - pode se tornar um caso médico. Hábitos alimentares são considerados doentios quando interferem na saúde física e mental, deteriorando até as relações pessoais e profissionais da pessoa.

As causas desses distúrbios são muitas: vão da predisposição genética ao esforço para se adequar a padrões estéticos estabelecidos por figuras famosas. Por envolver fatores tão variados, a própria definição de transtorno alimentar é objeto de discussão: os únicos que recebem essa classificação da Organização Mundial da Saúde são a anorexia e a bulimia.

Descritas desde o antigo Egito, essas doenças se tornaram muito mais comuns nas últimas décadas - fala-se inclusive em uma epidemia, gerada pelo culto ao corpo perfeito. Exageros à parte, essas síndromes afetam hoje cerca de $1 \%$ da população mundial, sobretudo mulheres adolescentes e jovens.

Apesar de terem em comum a preocupação com o corpo, existem diferenças fundamentais entre os dois distúrbios. "Meninas com anorexia têm uma grave distorção de sua autoimagem, enxergando-se sempre muito mais gordas do que são", diz o psiquiatra Fábio Salzano, do Hospital das Clínicas de São Paulo. Na busca por emagrecer cada dia mais, elas simplesmente param de comer e viram esqueletos humanos. Para ser considerada anoréxica, é preciso ter um peso muito abaixo do estabelecido como saudável.

Já a distorção de imagem de uma bulímica é bem mais sutil. Elas não querem engordar, mas adoram comer. Têm ataques compulsivos seguidos de muita culpa que procuram aliviar provocando vômito ou tomando laxantes e diuréticos. "As meninas bulímicas têm, necessariamente, peso normal ou acima do normal", diz Alexandre Azevedo, também do HC paulistano.

Mas o universo dos des vios de comportamento envolvendo comida ultrapassa a bulimia e a anorexia. O cardápio de problemas vai da incapacidade de perceber quando o estômago está cheio até a fixação por alimentos exóticos. Os tratamentos variam de acordo com a doença, mas podem incluir remédios, psicoterapia e reeducação alimentar. 


\section{Menu indigesto}

\section{Ortorexia}

Os ortoréxicos têm verdadeira fixação por uma alimentação saudável, sem químicas, agrotóxicos nem aditivos. Eles são obsessivos pela escolha e preparo dos alimentos e tentam impor essa vida natureba a quem estiver por perto. O problema pode estar relacionado a transtornos obsessivos-compulsivos ou sinalizar um início de anorexia.

\section{Distúrbio alimentar relacionado ao sono (DARS)}

Quem sofre desse mal levanta no meio da noite para atacar a geladeira e acorda no dia seguinte sem se lembrar de quase nada do que se passou durante a madrugada. Essas pessoas, que comem normalmente durante o dia, são, muitas vezes, sonâmbulas. Cerca de $5 \%$ da população pode apresentar o problema, sendo a maioria mulheres.

\section{Síndrome de Prader-Willi}

A doença, que afeta 1 em cada 10 mil crianças. é associada a retardo mental. A criança apresenta um apetite insaciável e uma necessidade de comer constantemente alimentos de alto valor calórico. De origem genética, está diretamente relacionada à obesidade precoce. As complicações decorrentes do excesso de peso podem levar à morte.

\section{Síndrome do gourmet}

O portador dessa síndrome se preocupa em comer de forma fina e sofisticada, e isso inclui a compra, a preparação, a apresentação e o consumo de pratos elaborados ou exóticos. Muito rara - tem apenas 34 casos descritos - essa doença parece estar relacionada a lesões cerebrais. Já foi descrita em dois artigos publicados na literatura médica.

Marina Bessa e Soraia Gama (Revista Superinteressante - Texto adaptado)

Disponível em: www.super.abril.com.br/ciencia/o-que-sao-transtornos-alimentares. Acesso em 20 de julho de 2015. 


\section{ATIVIDADE 10 - COMPARTILHANDO OS SABERES ADQUIRIDOS}

Para finalizar este seguimento de atividades, peça que os discentes levem alimentos para que todos possam compartilhar, para que assim coloquem em prática os momentos que vivenciaram ao longo das propostas realizadas.

Neste fim de sequência didática, o professor poderá discutir com os estudantes acerca de suas percepções ao longo de todas as atividades e promover uma discussão sobre alimentação saudável, explorando as relações da alimentação com os fatores sociais, culturais e psicológicos ressaltados ao longo deste material.

\section{Objetivo}

Compartilhar os conhecimentos adquiridos ao longo das atividades de ensino.

Refletir acerca das escolhas alimentares dos alunos.

\section{Materiais Necessários}

* Alimentos escolhidos pelo professor e pelos alunos.

\section{Descrição da Atividade de Ensino}

1. Na aula anterior proponha que os alunos levem alimentos para que possam ser compartilhados por toda turma.

2. Discuta com os educandos as escolhas dos alimentos levados e finalize este módulo de atividades com uma reflexão acerca da proposta de uma alimentação saudável e adequada 
Duração Estimada: 45 minutos.

\section{Avaliação}

A avaliação desta atividade envolve a escolhas dos alimentos levados pelos alunos, sendo assim, esta proposta será um feedback de todas as atividades realizadas anteriormente. 


\section{PARA SABER MALS...}

\section{Sites e Livros:}

Ministério do Desenvolvimento Social e Combate à Fome e Observatório de Políticas de Segurança Alimentar e Nutrição: www.ideiasnamesa.unb.br

Programa de Alimentação Escolar - Fundo Nacional de Desenvolvimento da Educação (FNDE): www.fnde.gov.br/programas/alimentacaoescolar

Rede Brasileira de Alimentação e Nutrição Escolar: www.rebrae.com.br

Slow Food Brasil: www.slowfoodbrasil.com

Vídeo Aulas, Materiais Didáticos e Jogos: www.sonutricao.com.br

BRASIL. Ministério da Saúde. Secretaria de Atenção à Saúde. Departamento de Atenção Básica. Guia alimentar para a população brasileira. $2^{\mathrm{a}}$ ed. Brasília: Ministério da Saúde, 2014.

CONTRERAS, J.; GARCIA, M. Alimentação, sociedade e cultura. Rio de janeiro: Editora Fiocruz, 2011.

DERAM, S. O peso das dietas: emagreça de forma sustentável dizendo não as dietas!. $1^{\mathrm{a}}$ ed. São Paulo: Sensus, 2014.

FLANDRIN, J. L.; MONTANARI, M. História da alimentação. São Paulo: Estação Liberdade, 1998.

POLLAN, M. Em defesa da comida: um manifesto. Rio de Janeiro: Intríseca, 2008.

RODRIGUES, L. P. F. Guia de promoção da alimentação saudável e sustentável para escolas. Brasîlia: Universidade de Brasîlia, Decanato de Extensão, 2011. 


\section{ATIVIDADES COMPLEMIENTARES}

Caça Palavras sobre os Transtornos Alimentares

\begin{tabular}{|c|c|c|c|c|c|c|c|c|c|c|c|c|c|c|}
\hline 0 & $\mathrm{G}$ & É & $\mathrm{D}$ & $I$ & Ç & Ç & $\mathrm{N}$ & B & $\mathrm{V}$ & $V I$ & Í & & 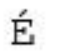 & $\mathrm{G}$ \\
\hline 0 & $\mathrm{~T}$ & $\mathrm{E}$ & $\dot{I}$ & $\mathrm{M}$ & Ç & $\mathrm{A}$ & $\mathrm{U}$ & ô & $Y$ & $I C$ & ô & U் & G & W \\
\hline C & $\mathrm{E}$ & $\mathrm{V}$ & $\hat{E}$ & $\mathrm{~T}$ & Ç & L & İ & ô & $\mathrm{E}$ & $\exists$ & $\mathrm{J}$ & ò & S & Á \\
\hline Q & $\mathbf{M}$ & $\mathrm{X}$ & Á & $\tilde{\mathrm{A}}$ & $I$ & Ú & $\mathrm{H}$ & G & À & & $Q$ & $\mathrm{~J}$ & A & $\mathrm{N}$ \\
\hline Á & $\mathrm{R}$ & $\mathrm{F}$ & $\mathrm{R}$ & $\mathrm{M}$ & $\mathrm{J}$ & $\mathrm{N}$ & $\mathrm{U}$ & Ç & 0 & & $\mathrm{U}$ & $Q$ & $\mathrm{H}$ & $\mathrm{P}$ \\
\hline $\mathrm{T}$ & $\mathrm{U}$ & ó & $I$ & S & $\mathrm{Z}$ & ò & $B$ & $\mathrm{H}$ & $\ddot{\mathrm{U}}$ & $\dot{J} \quad \bar{C}$ & Ü & $\mathrm{J}$ & $Q$ & B \\
\hline Í & 0 & $\mathrm{~A}$ & $\mathrm{~F}$ & $\hat{\mathrm{A}}$ & $\mathrm{V}$ & $\mathrm{A}$ & $I$ & $x$ & $E$ & $E$ & $R$ & 0 & $\mathrm{~N}$ & A \\
\hline Õ & $\mathrm{G}$ & $\mathrm{F}$ & $\tilde{\mathrm{A}}$ & $\hat{E}$ & $\mathrm{~V}$ & $7 \mathrm{C}$ & À & $\mathrm{V}$ & 0 & $D I$ & L & Á & $Q$ & $Q$ \\
\hline 0 & $E$ & $\mathrm{~A}$ & Í & $\hat{\mathrm{A}}$ & P & É & $F$ & Á & P & 2 & Ú & V & $\mathrm{Y}$ & $\mathrm{S}$ \\
\hline$\ddot{\mathrm{U}}$ & $\mathrm{M}$ & $\mathrm{S}$ & Ú & Á & ó & $\tilde{\mathrm{A}}$ & É & $R$ & $\mathrm{~K}$ & $\mathrm{k}$ & Ç & $\hat{\mathrm{A}}$ & Á & $\hat{\mathrm{E}}$ \\
\hline A & 0 & $\mathrm{~A}$ & $\mathrm{~K}$ & $\tilde{\mathrm{A}}$ & B & $\mathrm{V}$ & $7 \mathrm{C}$ & : $T$ & 0 & 01 & Í & B & $Y$ & $Q$ \\
\hline $\mathrm{F}$ & $\mathrm{R}$ & $\mathrm{T}$ & $I$ & $\mathrm{~L}$ & $\mathrm{~L}$ & I & $W$ & $\mathrm{~T}$ & $E$ & $E I$ & D & A & $\mathrm{R}$ & P \\
\hline Õ & $\mathrm{D}$ & $\mathrm{T}$ & $\hat{E}$ & $\tilde{\mathrm{A}}$ & $\mathrm{H}$ & I $\tilde{\mathrm{A}}$ & $\mathrm{H}$ & 1 Q & c̀ & 1 & $\mathrm{~N}$ & Í & $\mathrm{x}$ & Ú \\
\hline$Y$ & $\mathrm{~N}$ & $\hat{\mathrm{E}}$ & $\mathrm{L}$ & $\mathrm{U}$ & Õ & $\mathrm{T}$ & S & $\tilde{M}$ & $1 \mathrm{~F}$ & $\mathrm{R}$ & ô & Í & $\mathrm{H}$ & 0 \\
\hline I & $I$ & $\hat{E}$ & $\mathrm{U}$ & Z & W & I ó & $\mathrm{H}$ & I I & $\grave{z}$ & $\grave{A}$ & $\mathrm{~F}$ & G & $\mathrm{S}$ & $\mathrm{D}$ \\
\hline $\mathrm{T}$ & $\mathrm{S}$ & õ & $\hat{\mathrm{A}}$ & 0 & R & $\mathrm{T}$ & 0 & $R$ & $E$ & $E 2$ & $\mathrm{X}$ & I & A & $\mathrm{K}$ \\
\hline $\mathrm{J}$ & $\mathrm{P}$ & $I$ & $\mathrm{~K}$ & Á & C & : Ú & J & : Ú & J c & $6 \hat{z}$ & $\hat{\mathrm{A}}$ & $\mathrm{Y}$ & $\grave{A ̀}$ & $\hat{E}$ \\
\hline $\mathrm{N}$ & $\grave{A}$ & $\mathrm{~N}$ & $\tilde{\mathrm{A}}$ & $E$ & $\mathrm{R}$ & $\mathrm{C}$ & $I$ & $\hat{\mathrm{A}}$ & 1 & Ú & Á & $\mathrm{H}$ & $\mathrm{R}$ & $I$ \\
\hline $\mathrm{R}$ & $\mathrm{R}$ & $\mathrm{X}$ & $\mathrm{R}$ & $\tilde{\mathrm{A}}$ & C & $\therefore B$ & 3 ò & $\mathrm{F}$ & 0 & $\mathrm{C}$ & 0 & $\mathrm{U}$ & Í & $\tilde{\mathbb{A}}$ \\
\hline L & É & ò & C & $E$ & $I$ & [ ò & Ç & $5 \mathrm{~N}$ & $\mathrm{~T}$ & f́ I & $\mathrm{L}$ & $\mathrm{F}$ & $\mathrm{F}$ & $\tilde{\mathrm{A}}$ \\
\hline$\ddot{\mathrm{U}}$ & Í & $\hat{\mathrm{A}}$ & $\mathrm{x}$ & ô & ô & ô & $\mathrm{Z}$ & $\mathrm{C}$ & & $\begin{array}{l}\mathrm{J} \\
\end{array}$ & Ò & $\mathrm{M}$ & Í & $E$ \\
\hline D & Í & Ç & $\hat{E}$ & $\mathrm{~F}$ & 0 & $\dot{\mathrm{U}}$ & j Ç & 5 & & $I i$ & À & ò & ó & D \\
\hline É & $\mathrm{N}$ & $\mathrm{G}$ & $\mathrm{P}$ & $\ddot{\mathrm{U}}$ & $\mathrm{L}$ & LÉ & $\tilde{\mathrm{A}}$ & $\mathrm{J}$ & & $V \quad V$ & $W$ & $\mathrm{Y}$ & Ç & ò \\
\hline Í & $\mathrm{K}$ & ò & $\mathrm{U}$ & Ç & $Q$ & 2 & {$[\mathrm{I}$} & $\Delta D$ & $\hat{C}$ & $\hat{6}$ & $\tilde{\mathrm{A}}$ & V & C & $\mathrm{N}$ \\
\hline Á & $\mathrm{J}$ & É & $\mathrm{x}$ & D & É & $\mathrm{R}$ & $2 \mathrm{Z}$ & $\mathrm{N}$ & & & & À & $\mathrm{T}$ & $\mathrm{V}$ \\
\hline
\end{tabular}

ORTOREXIA

ANOREXIA

PRADERWILLI

SINDROMEGOURMET

BULIMIA 


\section{Dez Passos para uma Alimentação Adequada e Saudável}

Complete as lacunas com as dez indicações feitas pelo Guia Alimentar da População Brasileira (2014) para uma alimentação adequada e saudável:

11. Fazer de alimentos ou minimamente processados a base da alimentação.

12. Utilizar óleos, gorduras, sal e açúcar em ao temperar e cozinhar alimentos e criar preparações culinárias.

13. o consumo de alimentos processados.

14. Evitar o consumo de

15. Comer com e atenção em ambientes apropriados e, sempre que possível, com

16. Fazer compra em locais que ofertem variedades de alimentos ou minimamente processados.

17. habilidades culinárias.

18. Planejar o uso do para dar à o espaço que ela merece.

19. Dar preferência, quando fora de casa, a locais que servem feitas na hora.

20. Ser quanto a informações, orientações e mensagens sobre alimentação veiculadas em 
Palavras Cruzadas sobre Alimentação

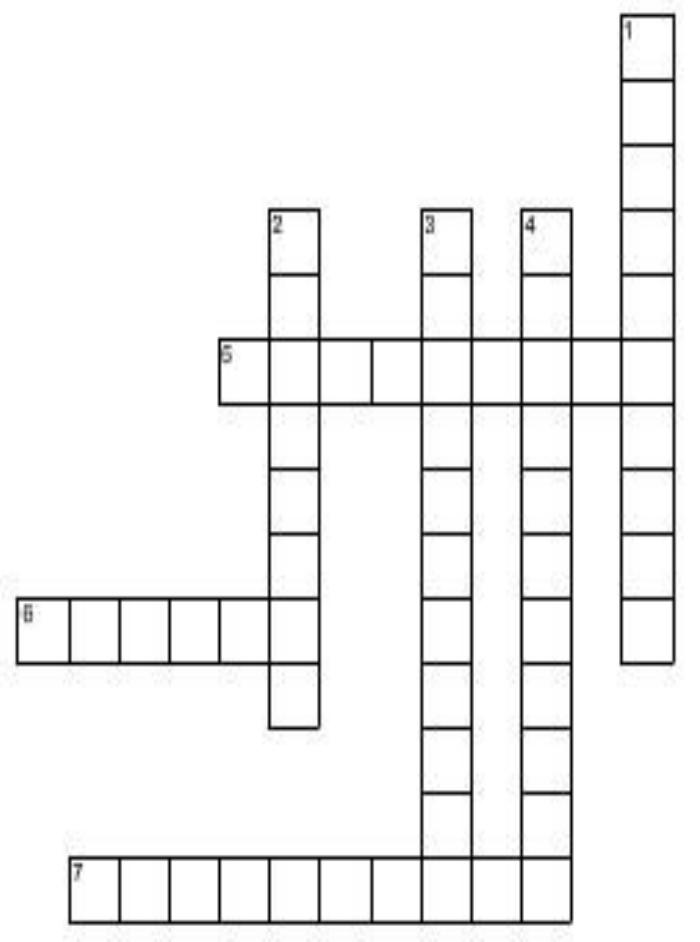

1. Fixação por uma alimentação saudável.

2. Formado a partir de diversos fatores: culturais, psicológicos e sociais.

3. Traço individual de cada pessoa.

4. Apresentam os primeiros sintomas geralmente na infância e adolescência.

5. Doença causada pelo acúmulo de gordura.

6. Medidas adquiridas com o intuito de emagrecimento.

7. Opções práticas e cômodas para a maioria das pessoas. 


\section{REFERÊNCIAS BIBLIOGRÁFICAS}

BARbOSA, N. V. S.; MACHADO, N. M. V.; SOARES, M. C. V.; PINTO, A. R. R. Alimentação na escola e autonomia: desafias e possibilidades. Ciências \& Saúde Coletiva, v. 18, n. 4, p. 937-945, 2012.

CONTRERAS, J.; GARCIA, M. Alimentação, sociedade e cultura. Rio de janeiro: Editora Fiocruz, 2011.

COSTA, M. F. Consumo alimentar: discurso científico em anúncios publicitários. Contemporânea, n. 13, v. 2, p. 131-140, 2009.

DERAM, S. O peso das dietas: emagreça de forma sustentável dizendo não as dietas!. $1^{a}$ ed. São Paulo: Sensus, 2014.

DOMENE, S. M. A. A escola como ambiente de promoção da saúde e educação nutricional. Psicologia USP, n.4, v. 19, p. 505-517, out./dez. 2008.

GAMBARDElla, A, M. D.; FRUTUOSO, M. F. P.; FRANCH, C. Prática alimentar de adolescentes. Rev. Nutr, n. 1, v. 12, p. 5-19, jan./abr. 1999.

GAVIDIA, V. El profesorado ante La educación y promoción de la salud em la escuela. Didáctica de las Ciencias Experimentales y Sociales, n. 23, p. 171-180, 2009.

GOMES, K. dos. S.; FONSECA, A. B. Programa nacional de alimentação escolar e suas possibilidades para a educação alimentar e nutricional: uma revisão da literatura. Atas do IX Encontro Nacional de Pesquisa em Educação em Ciências - IX ENPEC; 10 a 14 de novembro; Águas de Lindóia. São Paulo: 2013.

FREIRE, P. Educação e mudança. 34 ed. São Paulo: Paz e terra, 2011.

LOUREIRO, I. A importância da educação alimentar: o papel das escolas promotoras de saúde. Educação alimentar, v. 22, n. 2, p. 43-55, 2004.

MARTINS, D.; WALDER, B. S. M.; RUBIATTI, A. de M. M. Educação nutricional: atuando na formação de hábitos alimentares saudáveis de crianças em idade escolar. Rev. Simbio-Logias, v. 3, n. 4, p. 86-102, junho 2010. 
MOURA, N. C. de. Influência da mídia no comportamento alimentar de crianças e adolescentes. Segurança Alimentar e Nutricional, n. 1, v. 17, p. 113-122, 2010.

ORTIGOZA, S. A. G. O fast food e mundialização do gosto. Rev. Cadernos de Debate, v. 5, p. 21-45, 1997.

SANTOS, L. A. Da dieta à reeducação alimentar: algumas notas sobre o comer contemporânea a partir dos programas de emagrecimento na internet. Revista de Saúde Coletiva, n. 20, v. 2, p. 459-474. Rio de Janeiro: 2010. 